\title{
6. CYCLIC SEDIMENTATION IN THE CRETACEOUS OF DEEP SEA DRILLING PROJECT SITES 535 AND 540 (GULF OF MEXICO), 534 (CENTRAL ATLANTIC), AND IN THE VOCONTIAN BASIN (FRANCE) ${ }^{1}$
}

\author{
Pierre Cotillon and Michel Rio, Département des Sciences de la Terre, Laboratoire de Sédimentologie et \\ Laboratoire associé au Centre National de la Recherche Scientifique No. 11, Université Claude Bernard, \\ 27-43 Bd du 11 Novembre, 69622 Villeurbanne Cédex, France
}

\begin{abstract}
At DSDP Sites 534 (Central Atlantic) and 535 and 540 (Gulf of Mexico), and in the Vocontian Basin (France), Lower Cretaceous deposits show a very pronounced alternation of limestone and marl. This rhythm characterizes the pelagic background sedimentation and is independent of detritic intercalations related to contour and turbidity currents.

Bed-scale cycles, estimated to be $6000-26,000 \mathrm{yr}$. long, comprise major and minor units. Their biological and mineralogic components, burrowing, heavy isotopes $\mathrm{C}$ and $\mathrm{O}$, and some geochemical indicators, vary in close correlation with $\mathrm{CaCO}_{3}$ content. Vertical changes of frequency and asymmetry of the cycles are connected with fluctuations of the sedimentation rate. Plots of cycle thickness ("cyclograms") permit detailed correlations of the three areas and improve the stratigraphic subdivision of Neocomian deposits at the DSDP sites.

Small-scale alternations, only observed in DSDP cores, comprise centimetric to millimetric banding and millimetric to micrometric lamination, here interpreted as varvelike alternations between laminae that are rich in calcareous plankton and others rich in clay. The laminations are estimated to correspond to cycles approximately 1,3 , and $13 \mathrm{yr}$. in duration.

The cyclic patterns appear to be governed by an interplay of continental and oceanic processes. Oceanic controls express themselves in variations of the biogenic carbonate flux, which depends on variations of such elements as temperature, oxygenation, salinity, and nutrient content. Continental controls modulate the influxes of terrigenous material, organic matter, and nutrients derived from cyclic erosion on land.

Among the possible causes of cyclic sedimentation, episodic carbonate dissolution has been ruled out in favor of climatic fluctuations with a large range of periods. Such fluctuations are consistent with the great geographic extension shown by alternation controls and with the continuous spectrum of scales that characterizes limestone-marl cycles. The climatic variations induced by the Earth's orbital parameters (Milankovitch cycles) could be connected to bed-interbed alternations.
\end{abstract}

\section{INTRODUCTION}

The most striking character of Cretaceous pelagic successions consists of a bed-scale lithologic cyclicity named "limestone-marl alternation." This framework has been described on land in sequences of various ages (Gignoux, 1950; Bruckner, 1953; Carozzi, 1955; Lombard, 1956; Ziegler, 1958; Schwarzacher, 1964; Beaudoin, 1977; Le Doeuff, 1977; Weissert et al., 1979; and Fischer, 1980), as well as at many oceanic sites (for Cretaceous successions, see Hollister, Ewing, et al., 1972; Winterer, Ewing, et al., 1973; Simpson, Schlich, et al., 1974; Barker, Dalziel, et al., 1977; Dean et al., 1978; Bolli, Ryan, et al., 1978; Tucholke, Vogt, et al., 1979; Montadert, et al., 1979; Sibuet, Ryan, et al., 1979; Donnelly, Francheteau, et al., 1980; Ferry and Schaaf, 1981; Sheridan, Gradstein, et al., 1983).

Recently a research team at Université Claude Bernard, Lyon, studied cyclic sedimentation in Cretaceous sequences of the Vocontian Basin (southern subalpine ranges, southeastern France) and characterized the sediments by stratonomy, mineralogy, organic and inorganic geochemistry, and micropaleontology (Cotillon et al.,

\footnotetext{
${ }^{1}$ Buffler, R. T., Schlager, W., et al., Init. Repts. DSDP, 77: Washington (U.S. Govt. Printing Office).
}

1979, 1980; Darmedru et al., 1982). Cyclic variations, partly in phase partly out of phase with each other, affect mineralogic, microfaunal, and geochemical contents of the deposits with periodicities corresponding very often to the limestone-marl alternation.

Comparable cyclic variations have been recognized in bed-scale alternating deposits of many oceanic basins, with periods of $15,000-40,000$ yr. everywhere. Besides, a conspicuous basin-wide continuity is the main character of pelagic alternating layers, even in a centimetric scale (Cotillon et al., 1979, 1980).

For these reasons, the climatic variations, among other causes, seem most appropriate to explain all forms of the cyclicity observed in the bed-interbed succession, particularly the continental terrigenous influx (clays) and the biogenic calcareous one, mainly controlled by the planktonic production.

Aboard Glomar Challenger during the extension of Leg 76 and during Leg 77, P. Cotillon investigated typical pelagic cyclically bedded sequences drilled in the Lower Cretaceous of the Blake-Bahama Basin in the western Atlantic (Site 534; Sheridan, Gradstein, et al., 1983) and of the southeastern Gulf of Mexico (Sites 535 and 540) (Fig. 1). These sediments were analyzed by the same methods applied in the study of the Vocontian sequences. The Valanginian and Hauterivian intervals, the best 


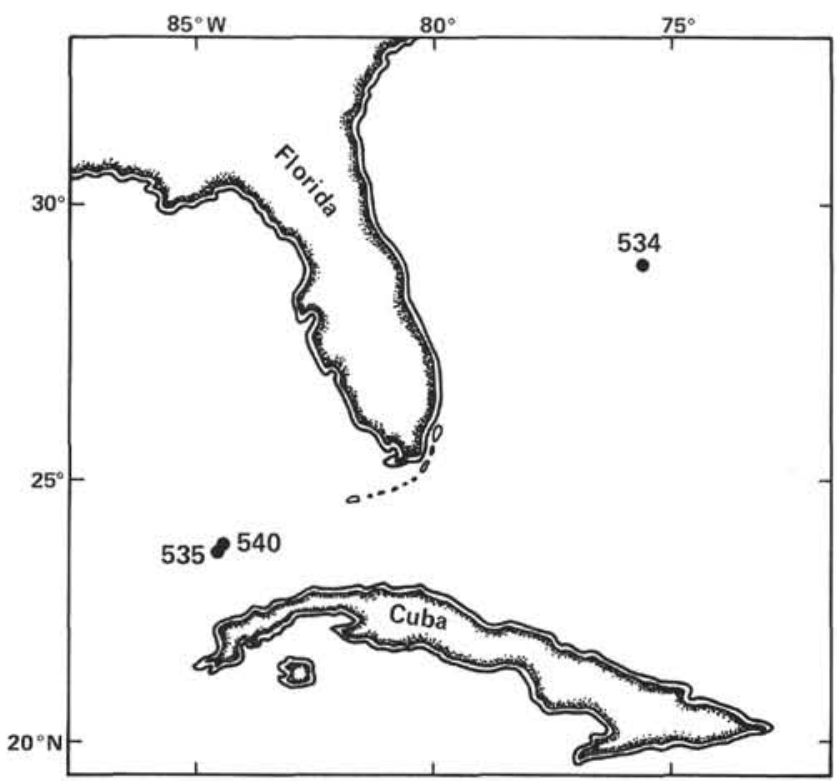

Figure 1. Location map of studied oceanic sites.

recovered in the two Atlantic sequences, were compared to the Vocontian coeval sequence to test the climate hypothesis of previous studies (Cotillon et al., 1979). The Cenomanian(?) of Site 535 and the Albian of Site 540 have provided additional data on cyclic sedimentation.

Studied material consists of core samples (Sites 535 and 540), core photography (Sites 534, 535, and 540), and samples from two land sequences in the Vocontian
Basin-the parastratotype of the Valanginian at Anglesand a Hauterivian section at Vergons, both in the vicinity of Castellane (southern subalpine ranges) (Fig. 2).

The comparison of the sections drilled at Sites 535, 540, and 534 with those at Angles and Vergons is based on the study of lithologic sequences and their limestonemarl cycles (Table 1), as well as on petrographic, mineralogic, micropaleontologic, and geochemical data.

\section{LITHOSTRATIGRAPHY AND BIOSTRATIGRAPHY}

\section{Lithostratigraphy}

Figure 3 summarizes the sequences in the Vocontian Basin and at DSDP Sites 534, 535, and 540. For the DSDP sites, $100 \%$ recovery is assumed. In spite of considerable differences in thickness, all sections show the same trends: from Berriasian to lower Aptian, the sedimentation changes from highly calcareous to marly to more calcareous again, forming the Eocretaceous megacycle (Cotillon, 1971). There is a lithologic break, often sharp and sometimes outlined by a stratigraphic gap (Site 535, Angles), at the transition between lower and upper Aptian ("El event" of de Graciansky et al., 1982). It corresponds to the deposition of marly facies (black shales in the Atlantic, "blue marls" in the Vocontian Basin) on pelagic limestone; at Site 535, it is probably represented by a gap encompassing the entire upper Aptian.

Despite these common trends, the three sequences do differ. (1) Sites 535 and 540 are generally more calcareous. Particularly during the Albian at these sites, almost

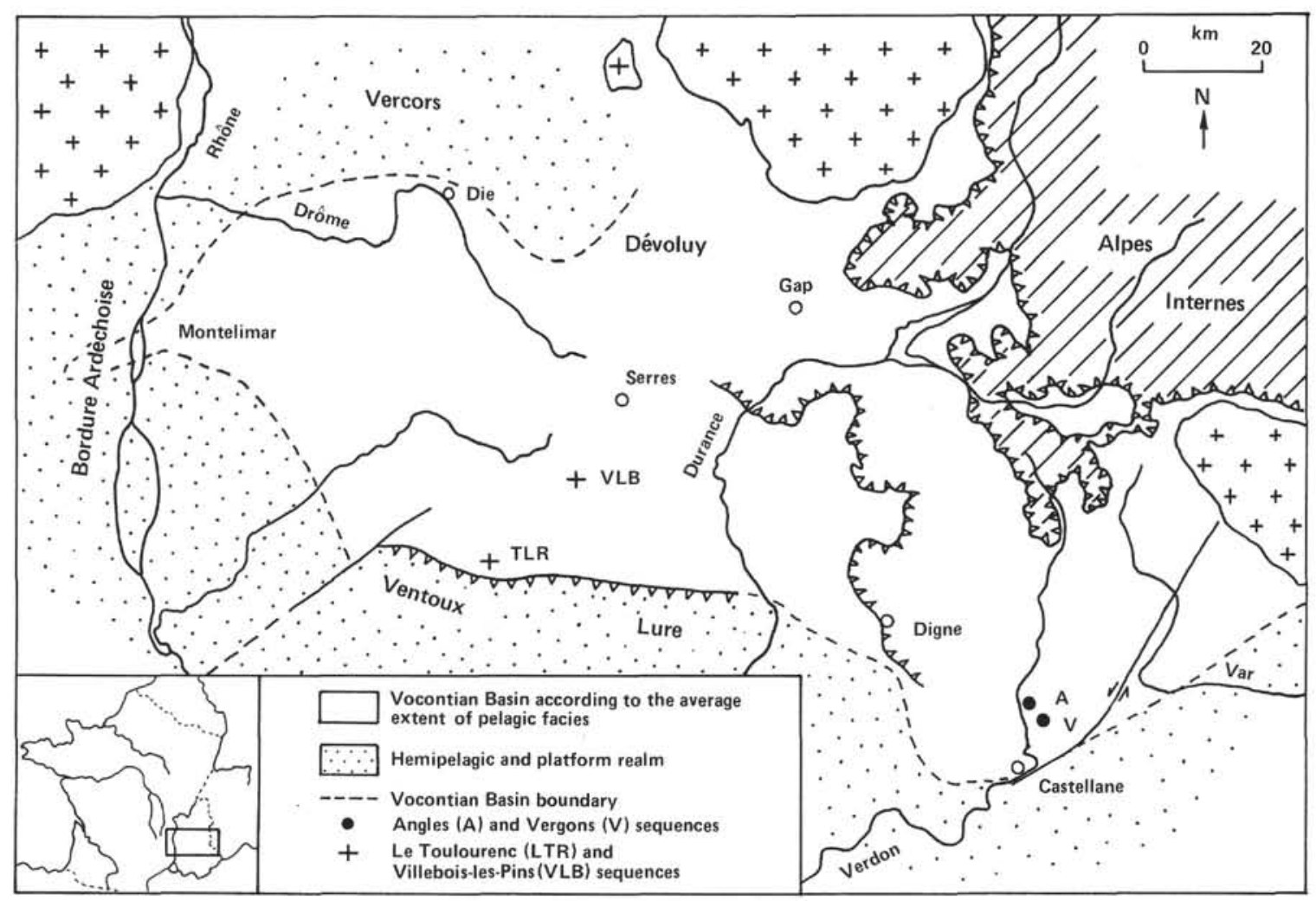

Figure 2. Vocontian Basin (southeastern France) and location of Angles and Vergons sequences. 
Table 1. Comparison of three Lower Cretaceous sequences (Holes 534A and 535, and Angles-Vergons).

\begin{tabular}{|c|c|c|c|c|}
\hline $\begin{array}{c}\text { Common } \\
\text { characteristics }\end{array}$ & Differences & $\begin{array}{l}\text { Hole } \\
534 \mathrm{~A}\end{array}$ & $\begin{array}{c}\text { Hole } \\
535\end{array}$ & $\begin{array}{l}\text { Angles- } \\
\text { Vergons }\end{array}$ \\
\hline \multirow{5}{*}{$\begin{array}{l}\text { Eocretaceous with one megacycle } \\
\text { limited by two calcareous } \\
\text { formations corresponding to } \\
\text { Berriasian and Barremo- } \\
\text { Bedoulian } \\
\text { Series with autochthonous marl- } \\
\text { limestone alternations } \\
\text { Allochthonous intercalations } \\
\text { (turbidites, debris flows, } \\
\text { contourites) with silicoclastic } \\
\text { and skeletal materials }\end{array}$} & Albian facies & Black shales & $\begin{array}{l}\text { Calcareous with } \\
\text { skeletal silt } \\
\text { and sand }\end{array}$ & $\begin{array}{l}\text { "Marnes } \\
\text { bleues" }\end{array}$ \\
\hline & $\begin{array}{l}\text { Bioturbation of } \\
\text { sediments }\end{array}$ & \multicolumn{2}{|c|}{$\begin{array}{l}\text { Partial-calcareous layers more } \\
\text { bioturbated }\end{array}$} & Total \\
\hline & $\begin{array}{l}\text { Mean oxygenation } \\
\text { of bottom } \\
\text { water }\end{array}$ & $\begin{array}{l}\text { Rather } \\
\text { deficient }\end{array}$ & $\begin{array}{l}\text { Slightly defi- } \\
\text { cient }\end{array}$ & Normal \\
\hline & $\begin{array}{l}\text { Water depth of } \\
\text { the deposition } \\
\text { (m) }\end{array}$ & $>3000$ & $1500-1700$ & $500-1500$ \\
\hline & $\begin{array}{l}\text { Total thickness } \\
\text { (m) (Valangin- } \\
\text { ian to Albian) }\end{array}$ & 431 & 557 & 795 \\
\hline
\end{tabular}

purely calcareous cycles occurred that have not been seen in the Atlantic, except at very localized points such as Site 369, off the Spanish Sahara (Lancelot, Seibold, et al., 1978) and Site 386, Central Bermuda Rise (Tucholke, Vogt, et al. 1979). Sedimentary condensations existed during the Barremian and Bedoulian. Conversely, at Site 534 more marly series occurred, particularly during the Barremian and Bedoulian, when sedimentation rates were higher than in the Gulf of Mexico. (2) At AnglesVergons, the lithology is the most diverse. Highly calcareous intervals occur in the lower Hauterivian (Acanthodiscus radiatus Zone) and upper Hauterivian. Conversely, marls are abundant in the upper Valanginian, and they contain pyritic fossils in the lower and upper Valanginian and middle Hauterivian.

Limestone-marl alternation dominates all three sequences; even in a monotonous lithology such as the Vocontian Aptian-Albian "blue marls," a weak cyclicity has been observed (Darmedru et al., 1982). These alternations, which are characteristic of autochthonous and pelagic deposits (see Discussion section), are often disturbed by sediment gravity-flow deposits with material from carbonate platforms or from their slopes. This allochthonous material is very common at Hole 534A (Sheridan, Gradstein, et al., 1983), where millimetric siltstone layers exist in the Hatteras Formation and where calcareous claystones, graded siltstones, sandstones, and debris flows have been described (particularly in the upper part [Hauterivian] of the Blake-Bahama Formation). Redeposited materials are mostly siliciclastic, rarely skeletal; generally, they are associated with marly and more or less carbonaceous layers and are interpreted as turbidites from the continental slope or (within lower Barremian) from carbonate platforms. Small slumps and microbreccias occur in Lithologic Subunit Vd of Hole 534A. At Site 535, Cenomanian(?) deposits reveal two successive intercalations of silts, skeletal sand, or even rubble. Detritic layers are millimeters to decimeters thick and contain current structures. These are also the result of gravity transport from platforms. In the same way, skeletal wackestones occur in the lower Valanginian and uppermost Berriasian (Cores 535-68 to 535-79), as well as synsedimentary or syncompactional flowing of sediment. At Site 540, Albian deposits are commonly polluted by skeletal material in the form of silty and sandy millimetric layers, often lenticular and ripple structured, sometimes graded (Units IV, Vb, VI). Massive debris intercalations are encountered in Unit VI only. At AnglesVergons, only the lower Berriasian contains some calciturbiditic and skeletal interlayers. But slump deposits are common, particularly in the Berriasian, lower Valanginian, lower Hauterivian, and Barremo-Bedoulian.

Interlayerings of allochthonous materials in the three sequences rarely obliterate bed-scale limestone-marl alternations of the pelagic background sedimentation. However, the allochthonous input often destroys the cyclicity on a laminar scale (millimeters).

\section{Biostratigraphy}

The Angles-Vergons section is representative of the Lower Cretaceous Vocontian sequences, the basis of many stratigraphic studies that have led, during the past 2 decades, to the modern Tethyan biozonations. As previously mentioned, the Valanginian sequence at Angles considered here was designated a parastratotype (Busnardo et al., 1979).

At Site 534, where stratigraphic subdivisions are based on foraminifers, nannofossils, calpionellids, and pollens (Sheridan, Gradstein, et al., 1983), boundaries are not always firmly identified.

At Site 535, the Berriasian and lower Valanginian are subdivided by calpionellids. Because of the absence of age-diagnostic organisms, the lower/upper Valanginian, Valanginian/Hauterivian, and Hauterivian/Barremian boundaries could be located only approximately (Buffler et al., this vol.). Subdivisions of the Barremian-Albian interval are based essentially on planktonic foraminifers and nannofossils.

\section{Other Elements of Comparison}

Common biostratigraphic markers (calpionellids and planktonic and benthic foraminifers) and typical Vocontian ammonites (Site 535) indicate open communication between the three sites. However, differences in the spectrum of microfauna as well as intensity and distribution of bioturbation suggest some differences in the depositional environments.

Intensive bioturbation is observed in the Angles-Vergons sequence; thus, delicate structures such as laminations are completely destroyed. Benthic microfaunas are 


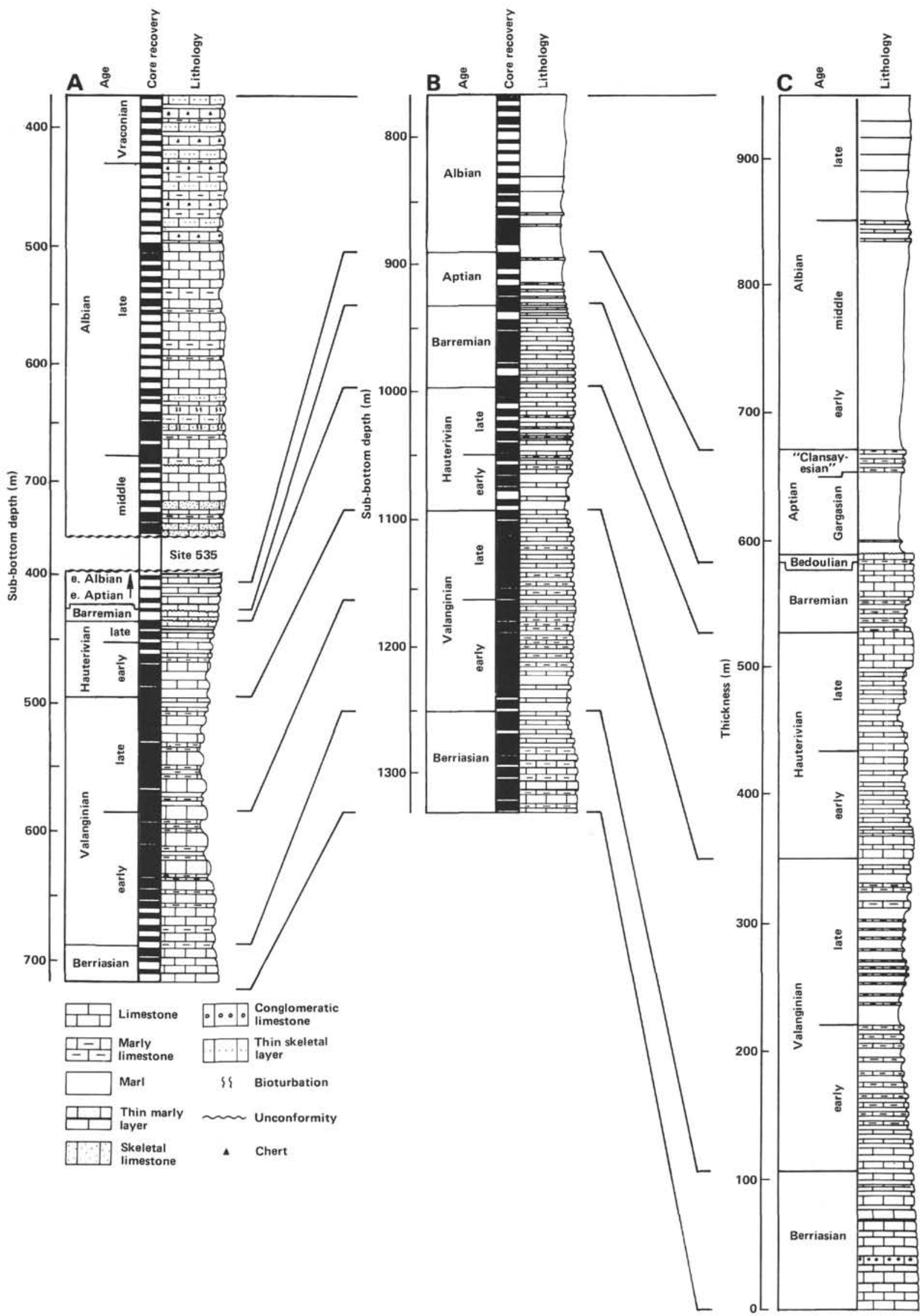

Figure 3. Lower Cretaceous sequences at three locations of the Tethyan realm. A. Southeastern Gulf of Mexico (Sites 535 and 540 ). B. Blake-Bahama Basin, off Florida, Central Atlantic (Site 534, DSDP Leg 76). C. Vocontian Basin (Angles-Vergons sequence), subalpine ranges, southeastern France. 
abundant and diversified (Moullade, 1966). This indicates an oxygenated environment with normal benthic life, even though boron titrations by Porthault (1978) indicate that the bottom water was slightly hypersaline as a result of some confinement of the basin. During the Barremo-Bedoulian, the sea was estimated to be 500$1500 \mathrm{~m}$ deep (Ferry, 1976).

At Sites 534 and 535 , only the very calcareous intervals were bioturbated, whereas marls and black shales were delicately laminated (Fig. 4). Overall, the data seem to indicate a more confined deep-water body at the DSDP sites, compared to the Vocontian Basin; in fact, the benthic microfauna is impoverished or totally absent in some levels at Site 534. Another cause for the poor microfaunal fraction is the water depth in the Blake-Bahama Basin during the Early Cretaceous (more than $3000 \mathrm{~m}$ according to Sheridan, Gradstein, et al., 1983) which also explains the poor preservation of many calcareous shells. At Site 535, the environment was intermediate between the Blake-Bahama Basin and the Vocontian Basin. Calculated depth was 1500-1700 m (site chapter, Sites 535, 539 , and 540, this vol.). Calcareous benthic microfossils are scarce, little diversified, and small, but they are not corroded and are always present. The preservation of microfaunas and nannofloras is worst in the Albian; this may be connected to the shallowing of the calcite compensation depth (CCD) postulated for this time interval in the Atlantic. Site 535 has another peculiarity: the presence of black shales in the alternations of Units III and V, i.e., in the lower and upper part of the Eocretaceous section.

All of the described sequences are representative of large areas. The Angles-Vergons sequence may be viewed as the pattern of the Lower Cretaceous in the Vocontian Basin, nearly $10,000 \mathrm{~km}^{2}$ in area. Indeed, the alternating layers that constitute this sequence are exactly the same throughout the Basin, except for their thickness. They interfinger only locally with materials redeposited by gravity processes (Ferry, 1976). The Blake-Bahama Formation (Berriasian to Barremian) at Site 534, the typesection of which has been described at Site 391 (Jansa et al., 1979), covers large areas in the Central Atlantic with no important variations. It exists on the Bermuda Rise (Site 387, Leg 43) and in the Cat Gap area [Sites 4 and 5 (Leg 1); Holes 99A and 100 (Leg 11)]. At Site 534, it is thickest and most detritic (Sheridan, Gradstein, et al., 1983). The Lower Cretaceous at Sites 535 and 540, with very detritic and calcareous Albian deposits, is similar to sequences described in provinces of west and central Cuba (Pardo, 1974).

\section{CYCLIC SEDIMENTATION IN THE EARLY CRETACEOUS AT SITES 535 AND 534 AND AT ANGLES-VERGONS}

\section{Cycles on the Scale of Beds}

The cyclic pattern of the deposition appears at many scales, from submillimetric laminations up to layers of tens of centimeters. The most obvious cyclicity in the three sites is on a scale of tens of centimeters (bed-interbed alternation). Bed-scale alternations correspond to

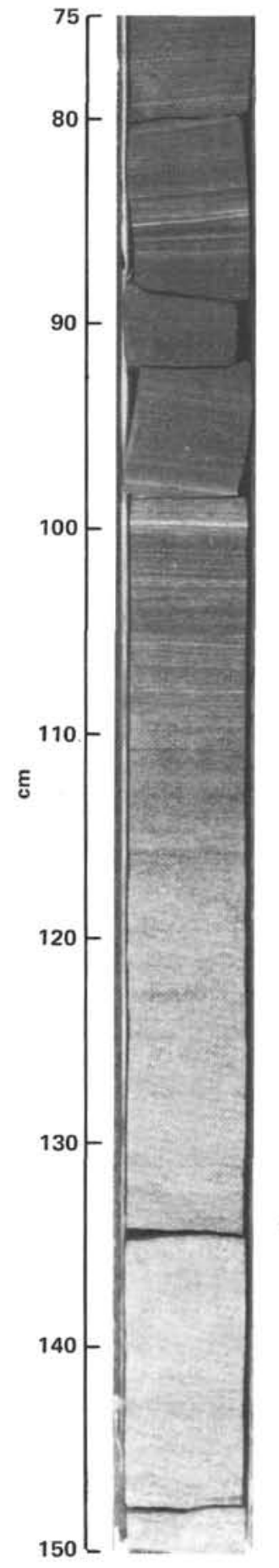

Figure 4. The most common distribution of bioturbation in the limestone-marl alternation [Cenomanian(?), Core 535-42]. 535-42-2, $87-92 \mathrm{~cm}$, laminated marl; $75-87$ and $92-117 \mathrm{~cm}$, laminated marly limestone; $117-150 \mathrm{~cm}$, burrowed limestone.

all sequential associations of layers thicker than $5 \mathrm{~cm}$, with a calcareous and a marly end-member. Below the threshold of $5 \mathrm{~cm}$, meteoric agents cannot differentiate beds and interbeds in land sequences when the difference in their $\mathrm{CaCO}_{3}$ content does not exceed $10 \%$; furthermore, the two extreme components of a cycle may be mixed by a moderate burrowing. 


\section{Sedimentologic Analysis}

Limestone-marl alternations are characterized by a cyclic renewal not only of the same lithologic sequence but also of the same faunistic, mineralogic, and geochemical one. Lithologically, the alternations consists of a repetition of binary or ternary sequences with units differing from each other by at least $5 \% \mathrm{CaCO}_{3}$ and displaying the pattern of succession: $\mathrm{a}-\mathrm{b}-\mathrm{a}-\mathrm{b}$ or $\mathrm{a}-\mathrm{b}-\mathrm{c}-\mathrm{b}-\mathrm{a}$. Facies encountered are: limestone $\left(>80 \% \mathrm{CaCO}_{3}\right)$, marly limestone $(60$ to $80 \%)$, and marl $(<60 \%)$ (Fig. 5). The calcareous unit of a cycle may be either a limestone or a marly limestone, whereas the marly unit may be either a marl or a marly limestone. Generally, the carbonate content varies gradually, and no sharp boundary separates cycle units (Fig. 6).

A cycle is described at first by its thickness, which is the distance separating two successive bottoms of the most argillaceous units. Other variables are (1) the proportions of each of the two or three units inside a cycle and (2) the asymmetry index of ternary cycles (ratio of the thicknesses of units separating the most calcareous unit of a cycle from the most argillaceous and immediately adjacent ones) (Fig. 7).

In the Vocontian Basin, Neocomian alternations consist generally of three bioturbated micritic units. In the upper Berriasian-lower Valanginian, the middle Hauterivian, and the lower Barremian intervals, cycles are divided in the same proportion in light gray or beige calcareous beds and dark gray marly interbeds (Fig. 8). In the lower Berriasian and Barremo-Bedoulian, where limestones prevail, interbeds are often reduced to thin, black, shaly centimetric layers distinctly separating limestone beds (Fig. 9). In the upper Valanginian, the cycles are thicker, and the more calcareous unit is a marly limestone or a fissile calcareous marl. Although homogeneous at first sight, upper Aptian and Albian "blue marls" show a weak alternating pattern, made up of subtle changes of color and hardness that are both related to a cyclic distribution of $\mathrm{CaCO}_{3}$ in the sediment (Darmedru et al., 1982).

At Site 535, the Lower Cretaceous is a sequence of light-colored limestone layers and darker layers of limestone or marl richer in clay and organic matter. Bioturbation affects mainly the most calcareous part of the deposits, whereas marly limestones are medium bioturbated and marls are laminated with little or no bioturbation (Fig. 4). This pattern is statistically true. The total percentages of light-colored limestone, gray marly limestone, and dark marl sections bioturbated at Site 535 are as follows: for the Hauterivian, 39,13 , and $3 \%$, respectively; for the Valanginian, 90,59 , and $11 \%$, respectively. However, fully bioturbated cycles or cycles with no bioturbation may be encountered. In Cenomanian(?) bed-scale limestone-marl alternations are faint in Core 535-18; they appear gradually through Cores 535-19 and 535-20 but become really distinct only in Cores 535-21 and 535-22. Cycles are generally short and binary, highly calcareous and bioturbated. The ternary cycle appears only in Core 535-31. In Cores 535-22 to 535-24 and Core 535-39, alternation is partially masked

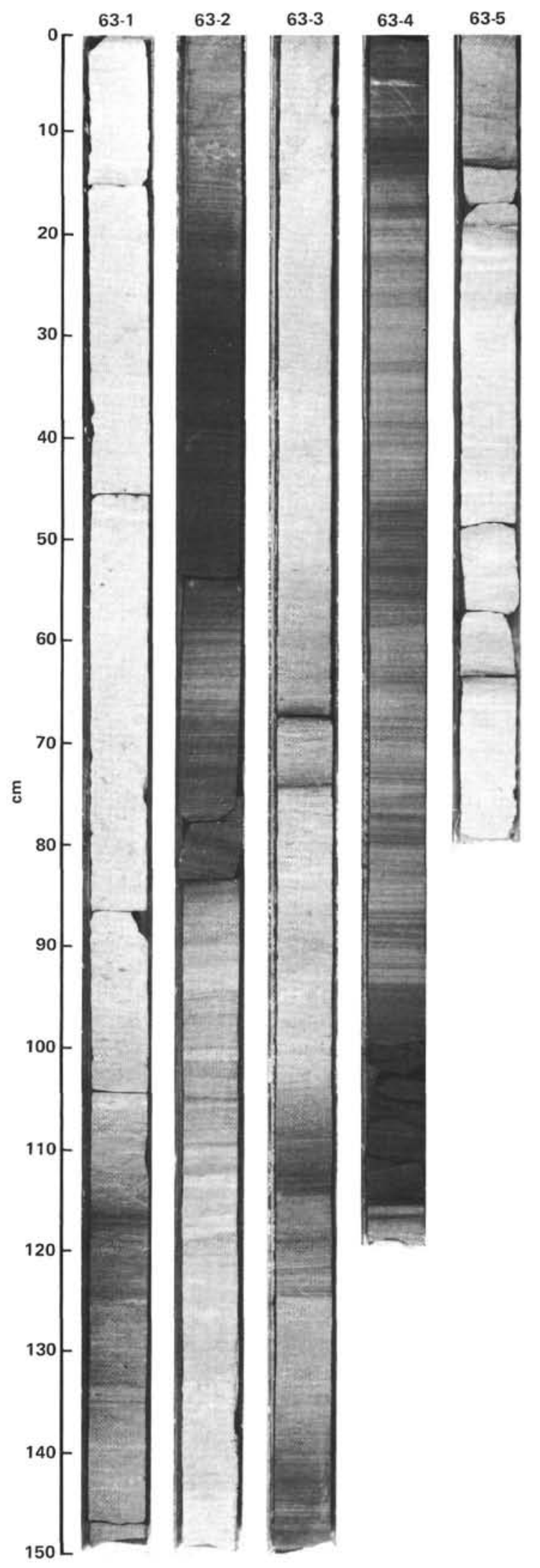

Figure 5. Binary and ternary sequences of alternating cycles. Valanginian Core 535-63. Burrowing in limestones (light) and the laminated structure in marls (dark gray), as well as in marly limestones (gray). 


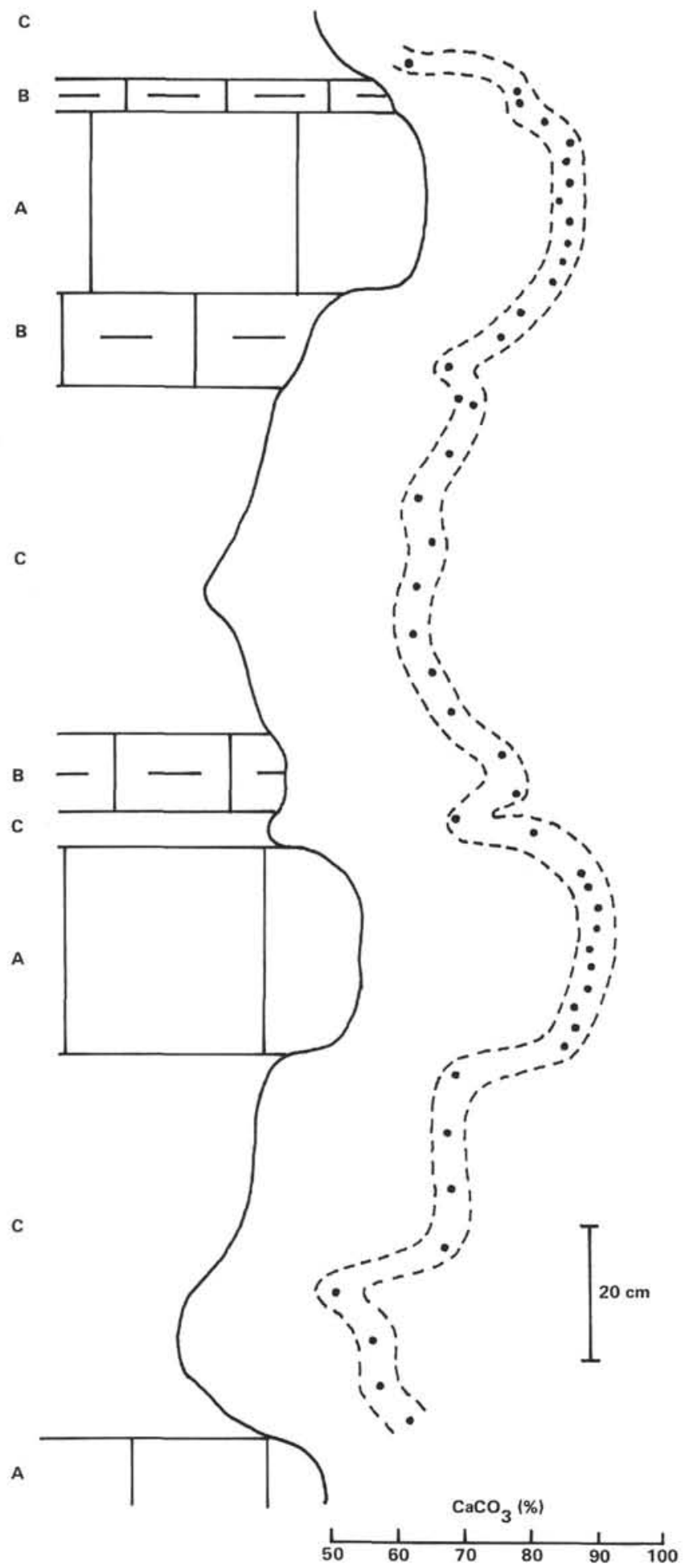

Figure 6. Distribution of $\mathrm{CaCO}_{3}$ through an alternating sequence (upper Hauterivian, Vergons). A. Limestone. B. Marly limestone. C. Marl.

by influx of shallow-water debris and coarse bioturbation. In Cores 535-34 to 535-36, enigmatic structures resembling microcross stratifications are observed in marly calcareous units of cycles (Fig. 10). The possible significance of these structures will be discussed later (see section on Overregional Control). The sequence from Ber-

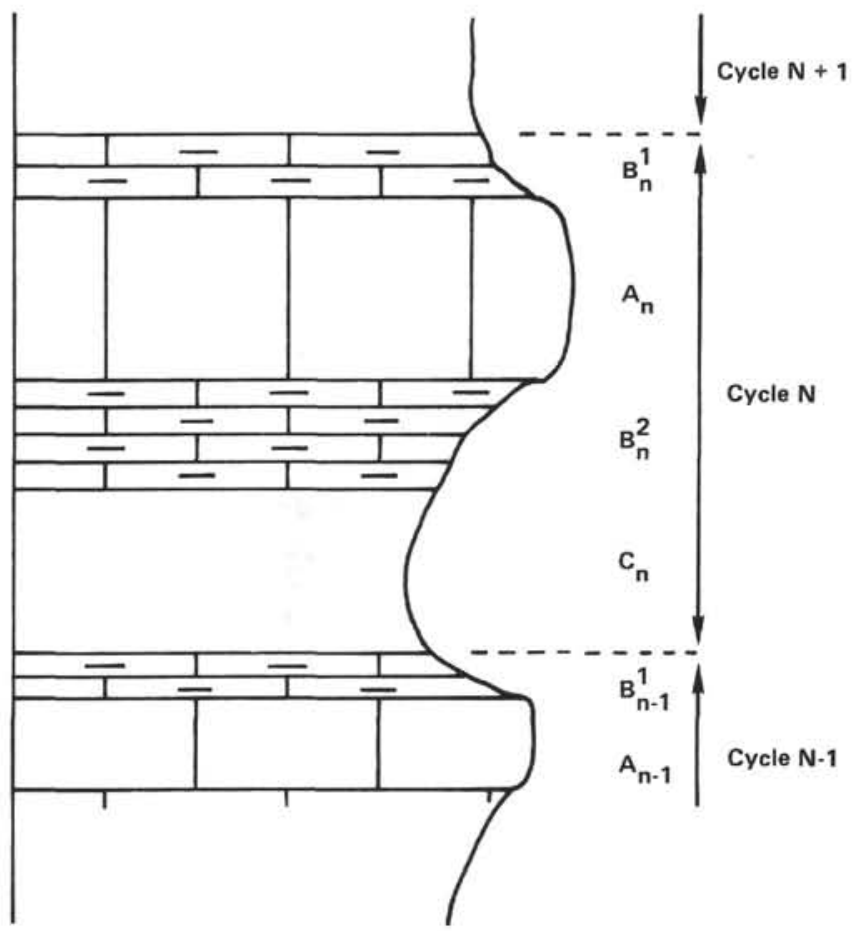

Figure 7. Conventions for cycle characterization: A, limestone unit; $\mathrm{B}$, marly limestone unit; and C, marly unit. Cycle $\mathrm{N}$ asymmetry = $\frac{B_{n}^{1}}{B^{1}+B^{2}} \cdot A_{n}, B_{n}, C_{n}$ are units of Cycle N. $B_{n}^{1}$ and $B_{n}^{2}$ are marly limestone units of Cycle $\mathrm{N}$ above and below the limestone unit.

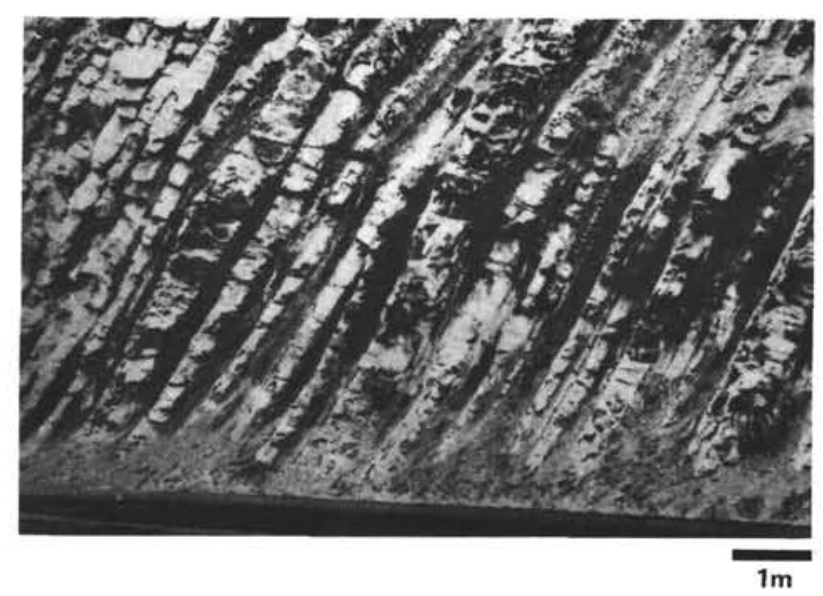

Figure 8. Alternating Hauterivian sequence at La Charce (Drôme, Vocontian Basin). Equal average proportions between beds and interbeds.

riasian to Aptian consists of ternary cycles, symmetrical or asymmetrical, with rather highly bioturbated limestones and laminated marls. Microcross-bedding is present in Lithologic Unit IV, particularly in Cores 52, 56, 57 , and 58 of Hole 535. Binary cycles, such as in the Cenomanian(?), reappear in Unit V.

At Site 540, cycles are comparable to those of the Cenomanian(?) at Site 535; bioturbation is often very strong, destroying small cycles but sparing the thickest (Cores 540-71 to 540-77). However, cyclicity is never masked by 


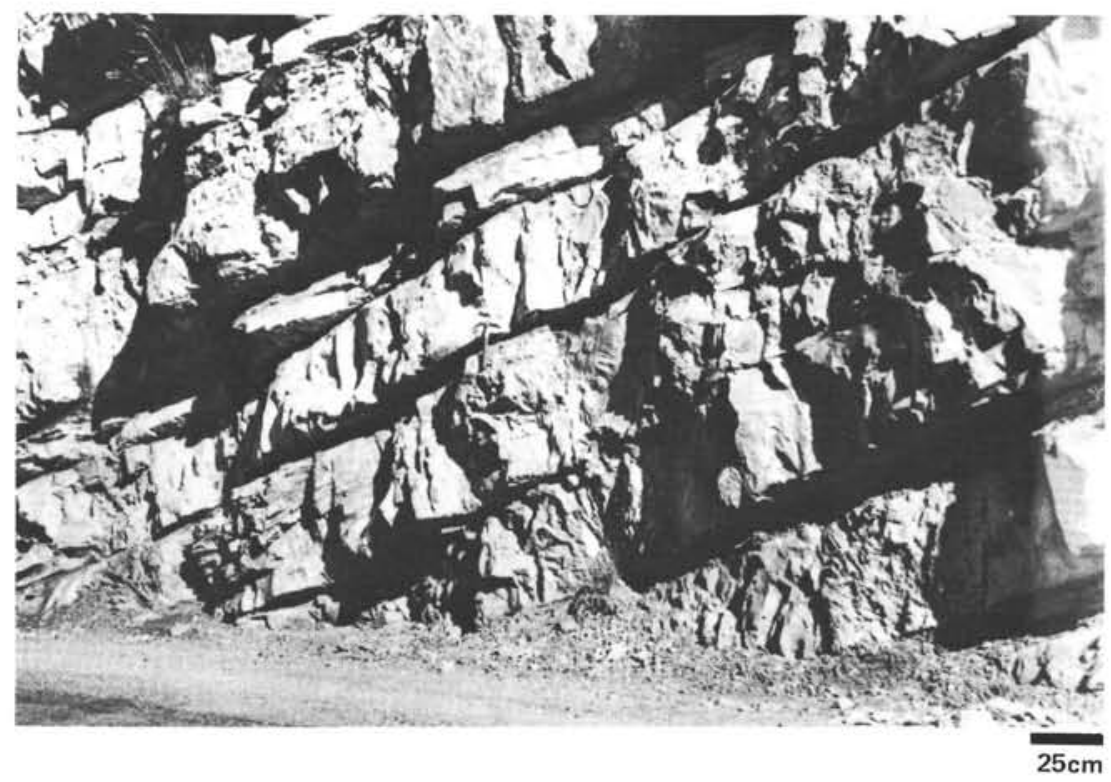

Figure 9. Upper Barremian at Angles (eastern Vocontian Basin, southeastern France). Alternation with prominent limestone beds; interbeds reduced to centimetric black-shale layers.

skeletal influxes even where they are volumetrically significant, as in Unit IV.

In Sites 535 and 540, light-colored limestones are less compacted than dark marls and black shales (burrows of the same organisms are more flattened in marls than in limestones) (Fig. 11). Also, light-colored limestones are often denser than marls; this may be related to a selective cementation in limestones. GRAPE diagrams, especially those for Cores 535-42 and 535-50 (Fig. 12), show this density relationship.

At Site 534, the nonredeposited sediments of the BlakeBahama Formation are nannofossil-radiolarian micritic limestones or chalk, marly nannofossil chalks, and marls in an alternating sequence (Sheridan, Gradstein, et al., 1983). Marls and marly chalks are finely laminated and unburrowed. Nannofossil chalk and limestone are moderately to very highly burrowed. The more calcareous layers are also the more cemented.

\section{Common Lithologic Features}

Cyclic alternations on the scale of beds (tens of centimeters) are common to these three Early Cretaceous series; they affect fine-grained sediments, including limestones, marly limestones, and marls. Chalks, marly chalks, and black marls such as "black shales" must be added for sequences of Sites 534 and 535 . These finegrained and cyclic deposits may be regarded as the pelagic background sediment (here called "autochthonous" material).

The bioturbation is not uniformly distributed in the lithologic cycles at the DSDP sites. Burrowing is most intensive in limestones and least common in marls which are mostly laminated. At Angles-Vergons, the bioturbation in all lithologies of a cycle is sufficient to destroy all lamination.

Allochthonous material from sediment gravity flows is inserted in autochthonous deposits at the DSDP sites.
They include current-deposited silt and sand, often skeletal in nature. At Sites 535 and 540, these materials do not destroy the cyclic pattern in the pelagic background; the situation is similar at Site 534, where many redeposited layers have been described (particularly from the Hauterivian), but where true calcareous turbidites with platform materials are relatively scarce (Cores 534A-53 to 534A-55). Contour-current deposit would result from either a redeposition from relatively close areas (continental slope or Blake-Bahama Basin margins) or a winnowing of autochthonous muds by contour currents.

\section{Distribution of Biota}

Previous studies on the distribution of biological remains in the Vocontian cycles concluded that the biota varies in a cyclic pattern that commonly follows the carbonate content (Cotillon et al., 1980; Darmedru et al., 1982; Darmedru, 1982). As a consequence, limestones, marls, and marly limestones can be distinguished by their microfauna. Limestones and marls contain the most specialized associations; benthic species are predominate in marls and planktonic species in limestones. Marly limestones, on the other hand, yield the most diversified populations and are particularly rich in planktonic foraminifers. The highest nannoconid concentrations are observed in limestones, whereas coccoliths prevail in marly interbeds (see also Noël, 1968; Manivit, 1979).

The Neocomian and Albian at Sites 535 and 540 have been studied in the same way as the Vocontian sections (disaggregation, using cryothermostat for separating limestones). The main results are the following.

1. Microfossils were counted in washed residues and gathered into 20 variables. For each site, data were analyzed by factor analysis. Results are very similar for the two sites and are summarized on Figure 13. Argillaceous samples cluster around the "benthic pole;" calcareous samples plot near the "radiolarian pole" $(80 \%$ 

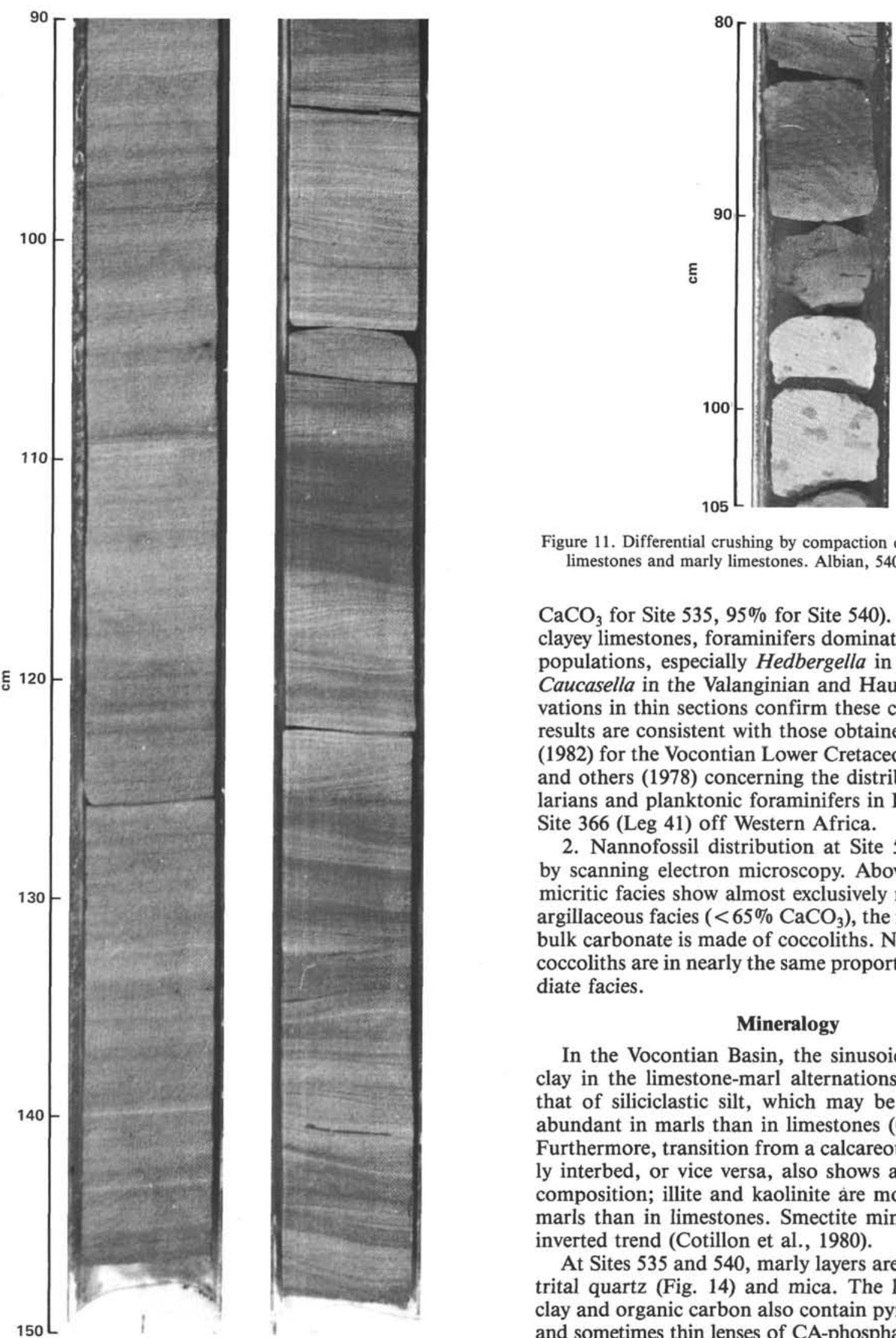

Figure 11. Differential crushing by compaction of burrows (dark) in limestones and marly limestones. Albian, 540-68-1, 80-105 cm.

$\mathrm{CaCO}_{3}$ for Site $535,95 \%$ for Site 540 ). In slightly more clayey limestones, foraminifers dominate the planktonic populations, especially Hedbergella in the Albian and Caucasella in the Valanginian and Hauterivian. Observations in thin sections confirm these conclusions. The results are consistent with those obtained by Darmedru (1982) for the Vocontian Lower Cretaceous and by Dean and others (1978) concerning the distribution of radiolarians and planktonic foraminifers in Eocene cycles at Site 366 (Leg 41) off Western Africa.

2. Nannofossil distribution at Site 535 was studied by scanning electron microscopy. Above $90 \% \mathrm{CaCO}_{3}$, micritic facies show almost exclusively nannoconids. In argillaceous facies $\left(<65 \% \mathrm{CaCO}_{3}\right)$, the most part of the bulk carbonate is made of coccoliths. Nannoconids and coccoliths are in nearly the same proportions in intermediate facies.

\section{Mineralogy}

In the Vocontian Basin, the sinusoidal variation of clay in the limestone-marl alternations is followed by that of siliciclastic silt, which may be 10 times more abundant in marls than in limestones (Cotillon, 1971). Furthermore, transition from a calcareous bed to a marly interbed, or vice versa, also shows a change in clay composition; illite and kaolinite are more abundant in marls than in limestones. Smectite minerals follow an inverted trend (Cotillon et al., 1980).

At Sites 535 and 540, marly layers are enriched in detrital quartz (Fig. 14) and mica. The layers richest in clay and organic carbon also contain pyrite, fish debris, and sometimes thin lenses of CA-phosphate. Small rhombic crystals of dolomite are often observed, with proportions up to $40 \%$. Their average frequency is higher in marls than in limestones (Fig. 15), particularly from
Figure 10. Cross-bedding-like structures by piling of "pseudoripples," here interpreted as compaction features. Cenomanian(?), 535-34-2, $90-150 \mathrm{~cm}$. 


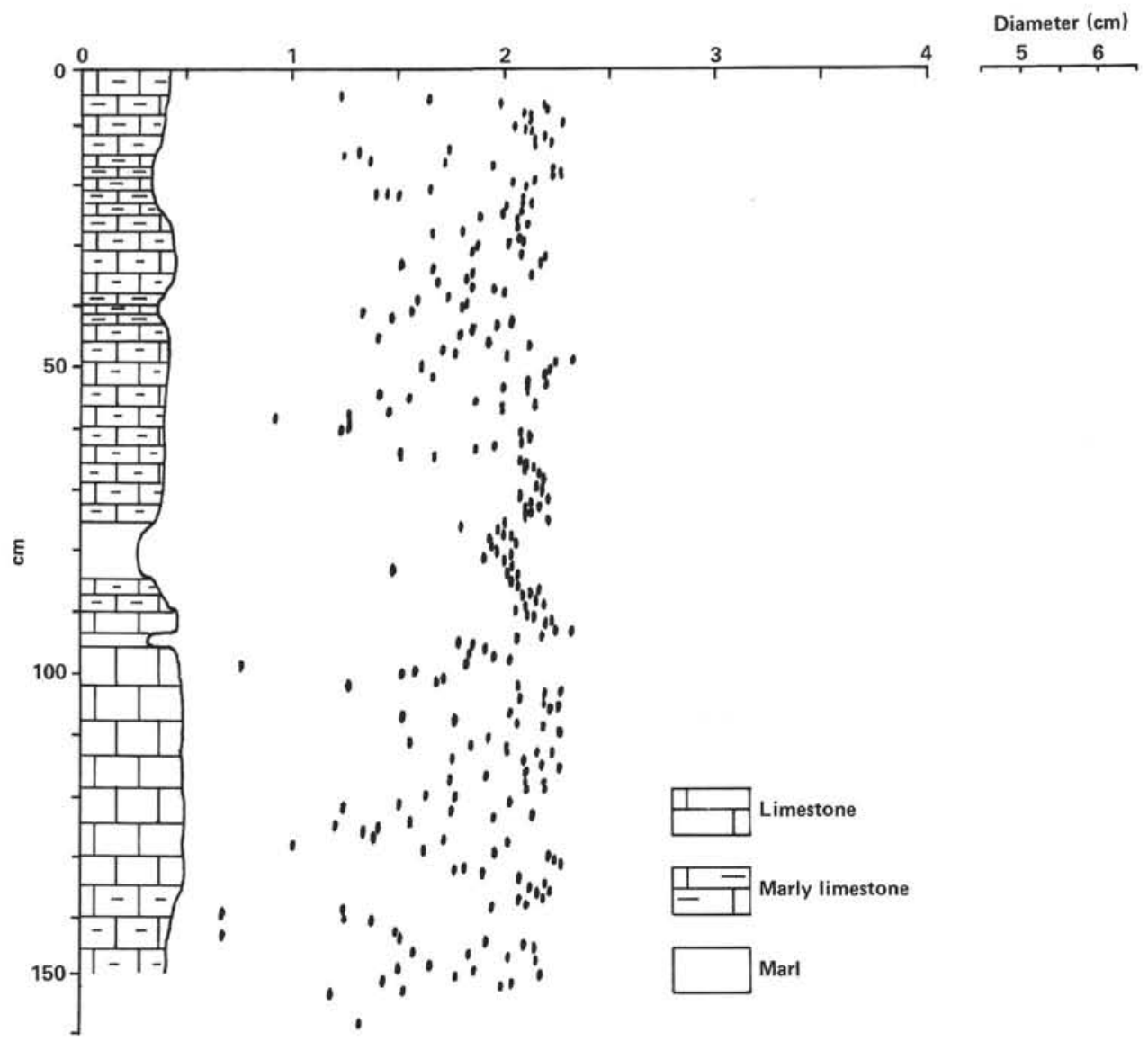

Figure 12. Distribution of density through an alternating sequence as shown by a GRAPE density diagram, Section 535-50-2.

Cores 535-40 to 535-68. Dolomite crystals formed before sediments were totally compacted (Fig. 16). X-ray diffractometry of 64 samples did not show a correlation between concentration of clay minerals and carbonate content. However, the crystallinity of illite (half-height width of 001 peak) is slightly higher in marls than in limestones (Fig. 17).

\section{Geochemistry}

Geochemical differences have been found between beds and interbeds of the "faisceau du Toulourenc," an upper Valanginian marker sequence that is $6-16 \mathrm{~m}$ thick, traced over the whole Vocontian Basin (Cotillon et al., 1980). Calcareous beds are enriched in $\mathrm{Fe}, \mathrm{Mg}$, and $\mathrm{Sr}$, whereas marly interbeds are enriched in $\mathrm{K}, \mathrm{Li}$, and $\mathrm{Zn}$ (in calcareous bulk) and in $\mathrm{Zr}, \mathrm{Nb}, \mathrm{Rb}$, and $\mathrm{Ni}$ (in terrigenous bulk) (Jouchoux, 1982).

Oxygen and carbon isotopes. In Valanginian deposits of the Vocontian Trough, oxygen and carbon isotopic ratios are different for limestones, marls, and marly limestones. Limestones are statistically richer in ${ }^{18} \mathrm{O}$ and ${ }^{12} \mathrm{C}$ than are marls. Weissert et al. (1979) obtained a similar result, especially with ${ }^{12} \mathrm{C}$ in the upper Majolica Formation (Barremian), Lombardian Alps, Italy; and de Boer (1982) did so in Umbrian middle Cretaceous.

In the southeastern Gulf of Mexico, analysis of 113 samples shows a difference between beds and interbeds in most of the cores at Site 535, interbeds being enriched with ${ }^{18} \mathrm{O}$ (Fig. 18). This trend is not observed for the Albian section at Site 540 (Fig. 19). Furthermore, ${ }^{18} \mathrm{O}$ contents decrease with burial at Site 535. At the same site, many calcareous beds are slightly enriched in ${ }^{13} \mathrm{C}$. On the other hand, the average value of ${ }^{13} \mathrm{C}$, calculated for four stratigraphic units, may be positively correlated with the corresponding sedimentation rates (Fig. 20).

Calcareous beds of the upper Valanginian are depleted in ${ }^{18} \mathrm{O}$ and slightly enriched in ${ }^{13} \mathrm{C}$ compared to those of the Vocontian Basin (Fig. 21).

Organic matter. Thirty-nine samples collected from various lithologies at Site 535 were analyzed by Deroo and Herbin (Institut Français du Pétrole) to determine their organic carbon contents, hydrogen indexes, and oxygen indexes (Deroo et al., 1978). Figures 22 and 23 summarize the main results of this analysis. Figure 22 clearly shows a negative correlation between organic carbon and $\mathrm{CaCO}_{3}$ content. For Valanginian sediments, organic carbon decreases through the following lithologic suite: dark gray laminated marl, gray laminated marl, gray laminated marly limestone, laminated beige limestone, and beige limestone (above $94 \% \mathrm{CaCO}_{3}$ ). Figure 23 shows a nearly total separation between beige limestones (with generally small hydrogen indexes and large oxygen indexes) and the marls and marly limestones; laminated beige limestone data are more scattered through 

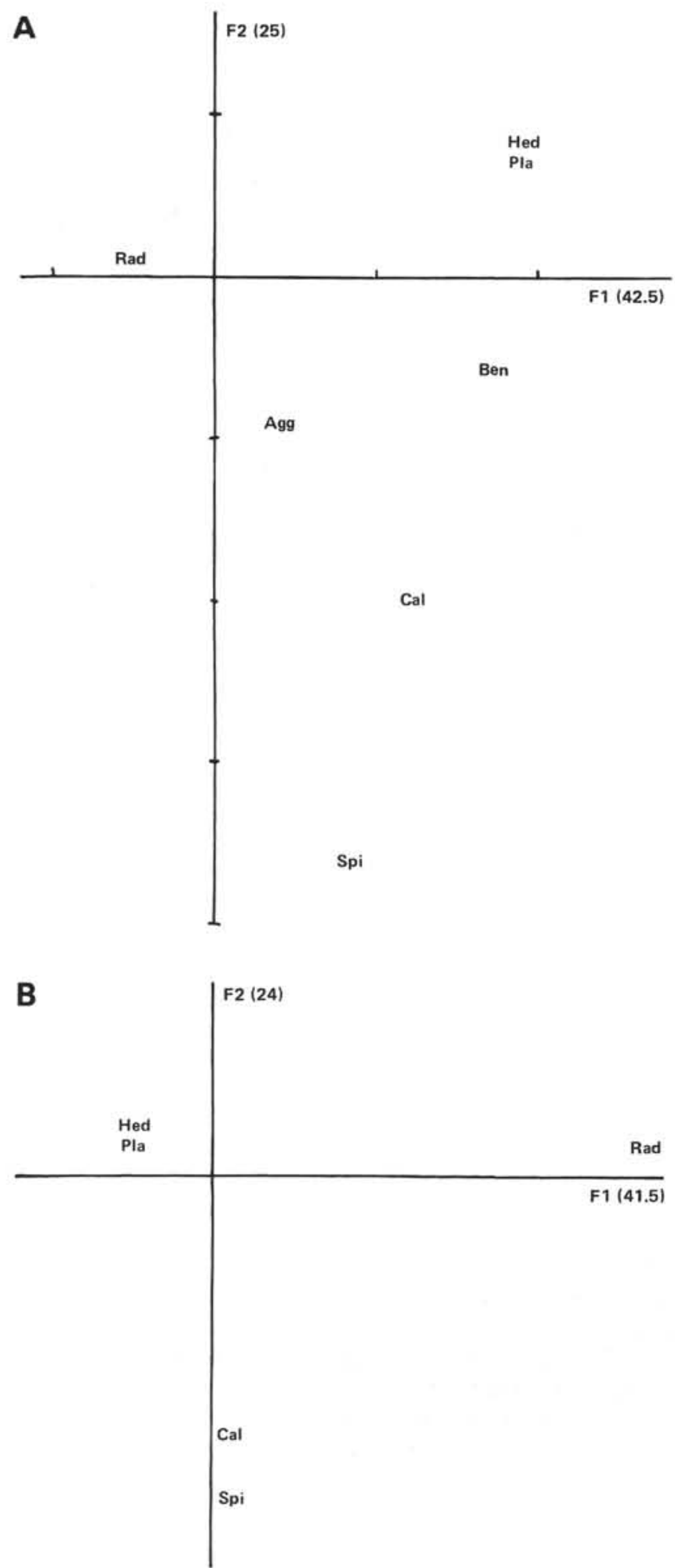

Figure 13. Correspondence analysis for microfaunal content of Lower Cretaceous deposits at Sites 535 (A) and 540 (B). Projection of main and additional variables on the two factor-planes. Main variables: Hed, Hedbergella; Rad, radiolarian; Spi, Spirillina. Additional variables: Agg, agglutinating foraminifers; Ben, benthic foraminifers; Cal, calcareous foraminifers; Pla, planktonic foraminifers.

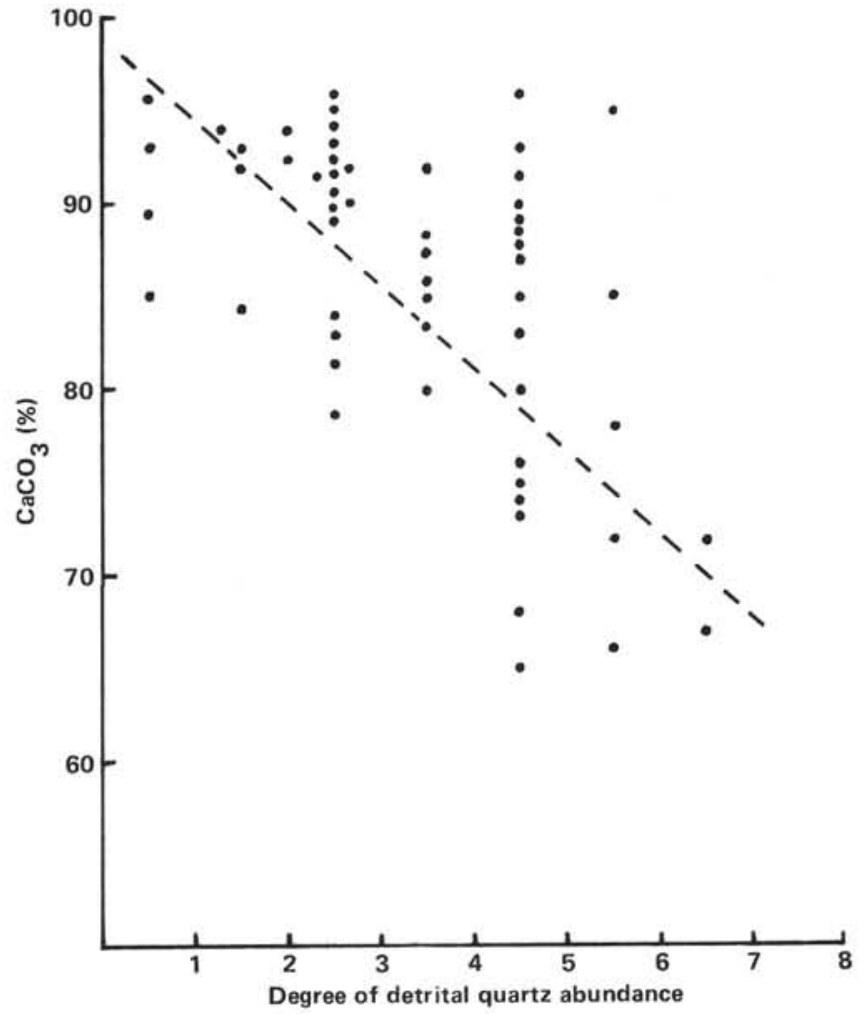

Figure 14. Detrital quartz abundance estimated in thin sections.

the diagram. Organic matter is essentially of marine origin.

\section{Statistical Analysis of the Limestone-Marl Cycles}

Because of poor recovery $(21 \%)$ and drilling disturbances in the Barremian and Aptian deposits at Site 535 , only the Valanginian-Hauterivian sequences of Sites 535, 534, and Angles-Vergons will be considered in this study. The Cenomanian(?) of Site 535 and the Albian of Site 540 will also be discussed.

Frequency of cycles. At each site, we counted the number of cycles in all stratigraphic units mentioned above, distinguishing major cycles and minor cycles. Conventionally, major cycles are at least $10 \mathrm{~cm}$ thick, with lithologic members well differentiated and each thicker than $2 \mathrm{~cm}$. Minor cycles are at least $5 \mathrm{~cm}$ thick, have poorly differentiated lithologic components, and are included in major cycles. In the Angles-Vergons series, only Valanginian and Hauterivian major cycles have been counted, because weathering is not always able to reveal the subtle differences in $\mathrm{CaCO}_{3}$ content that characterize the minor cycles. We can estimate the mean duration of cycles if we assume that they accumulated continually with the pelagic rain (Table 2 ). For comparison, some durations calculated by different authors for the Lower and middle Cretaceous pelagic deposits are listed in Table 3.

For intervals with good recovery of sediments in DSDP sites, such as the Valanginian, the number of major cycles is nearly the same in each sequence. In turn, the number of minor cycles calculated for different strati- 


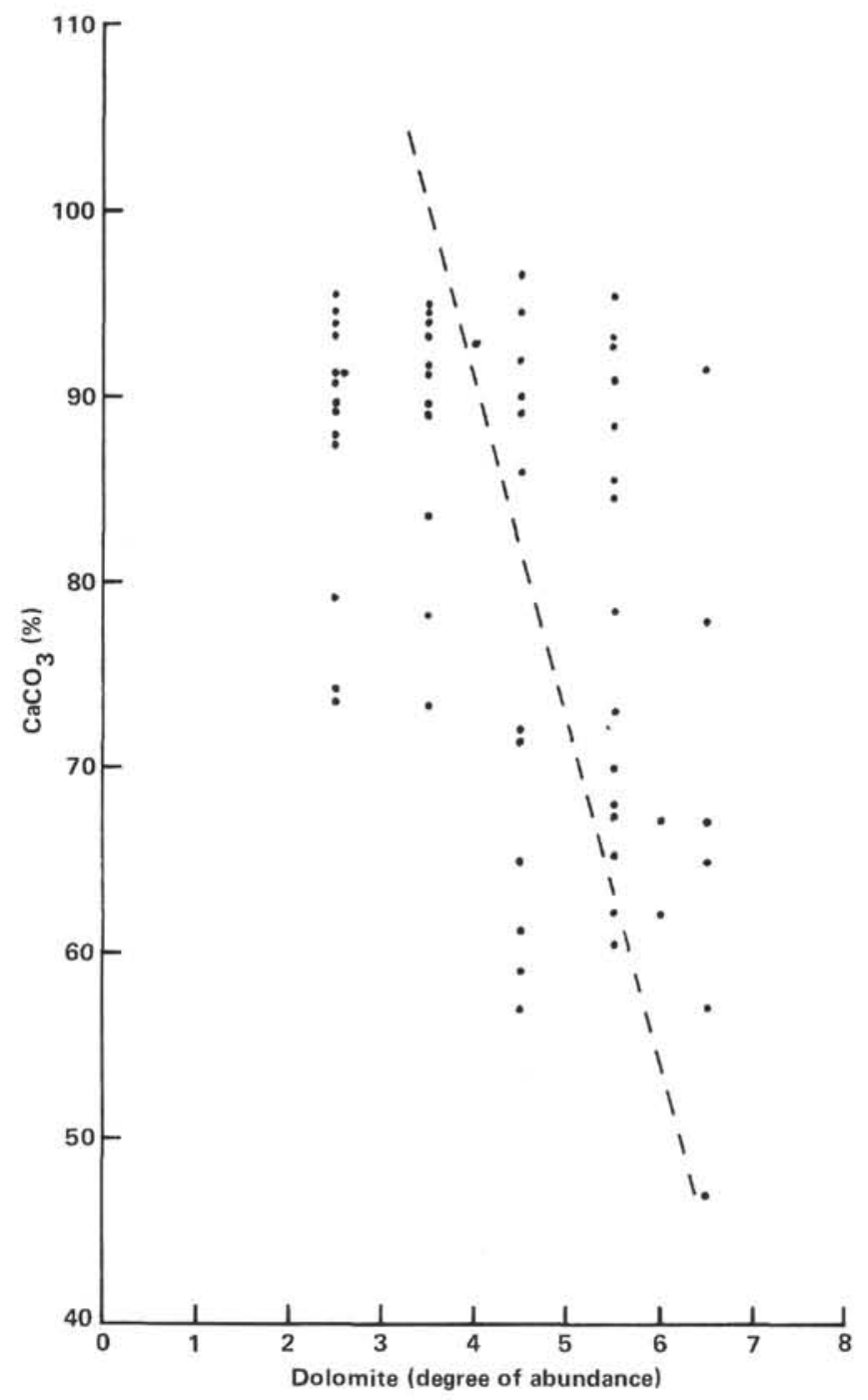

Figure 15. Diagenetic dolomite abundance in deposits versus their $\mathrm{CaCO}_{3}$ content. There are seven degrees of estimated abundance for automorph dolomitic rhombs observed in rock thin sections.

graphic units varies greatly according to sites and correlates positively with the sedimentation rates (Fig. 24).

Furthermore, we constructed curves showing the variation of the frequency of cycles per core, corrected for recovery (per intervals of $15 \mathrm{~m}$ for the Angles-Vergons succession), (Figs. 25-27). Each of them reveals largescale variation ("megacyclicity"). The curves of major cycles reveal similar evolutions for the three sites until the late Valanginian (Himantoceras trinodosum Zone of the Angles-Vergons succession) and for the entire Neocomian in the two DSDP sites. In addition, peculiar points appear at the same levels in the three sites; they are situated at changes in evolutionary trends. The one (A) at the lower/upper Valanginian transition, the other (B) just above the Valanginian/Hauterivian transition (Fig. 25). Likewise, curves for the Albian of Site 540 and the Cenomanian(?) of Site 535 have some parallel trends along the path XYZ (Fig. 26).

As noted above, the curves of minor cycles are expected to express variations of the sedimentation rate. For Sites 534 and 535, these curves outline rather similar

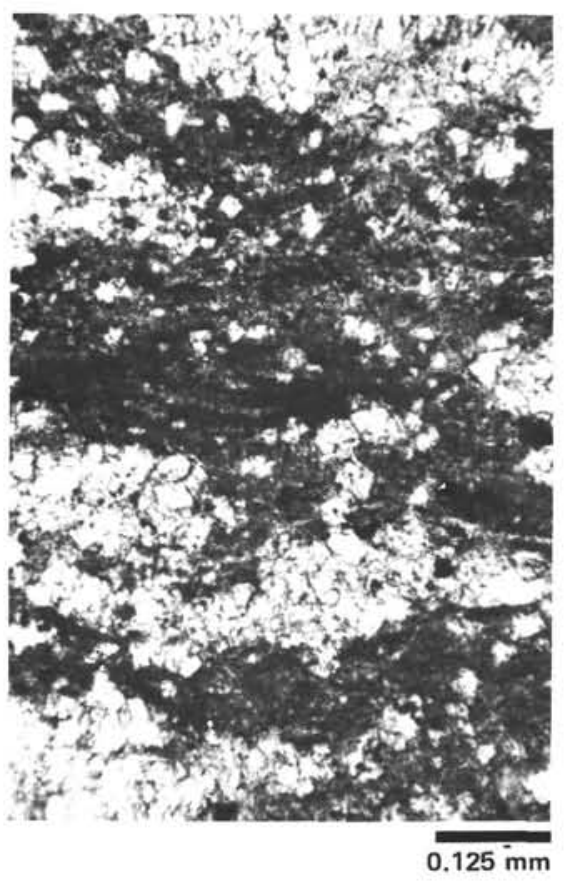

Figure 16. Early diagenetic dolomite rhombs in a marly limestone. The crystal formation was achieved before a total compaction as demonstrated by the deformation of dark laminae around the dolomite (Valanginian, Sample 535-57-4, 53-54 cm).

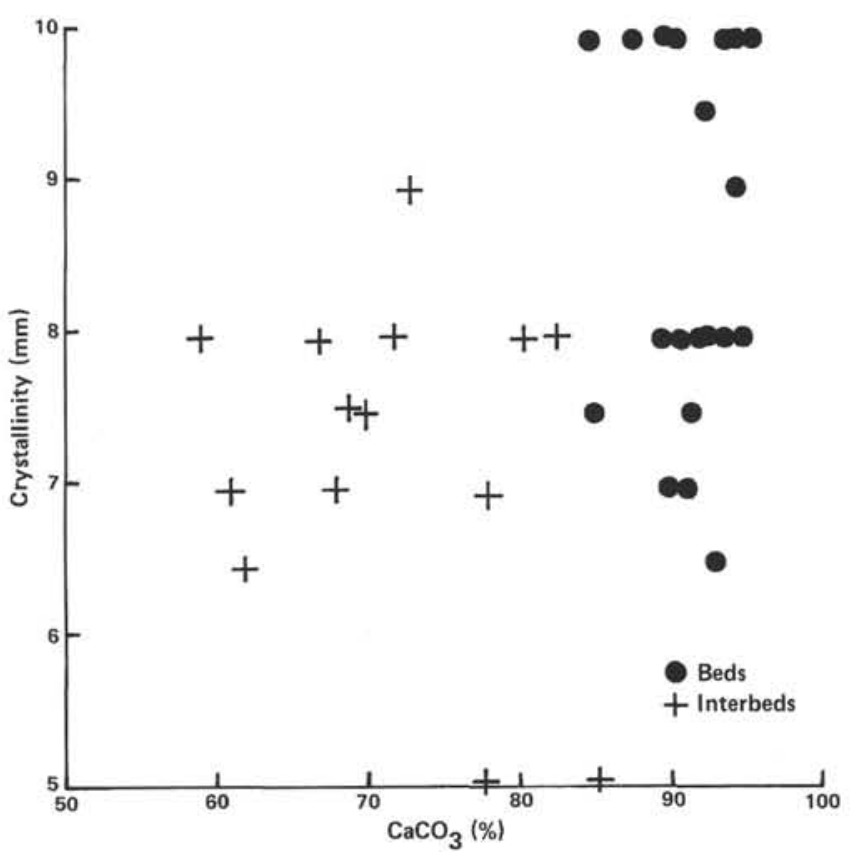

Figure 17. Illite crystallinity in beds and interbeds in the Lower Cretaceous at Site 535. Crystallinity is expressed as half-height width of 001 peak of illite of glycolled samples.

evolutions for the Neocomian (see correlation points $C$ to $\mathrm{H}$, Fig. 27) and are composed of megacycles covering 6,8 , or 10 cores. There is no evident correlation between these curves and the lithologic variations in the sequences.

Curves of minor-cycle frequency and burrowing intensity in the Valanginian-Hauterivian and Cenomani- 


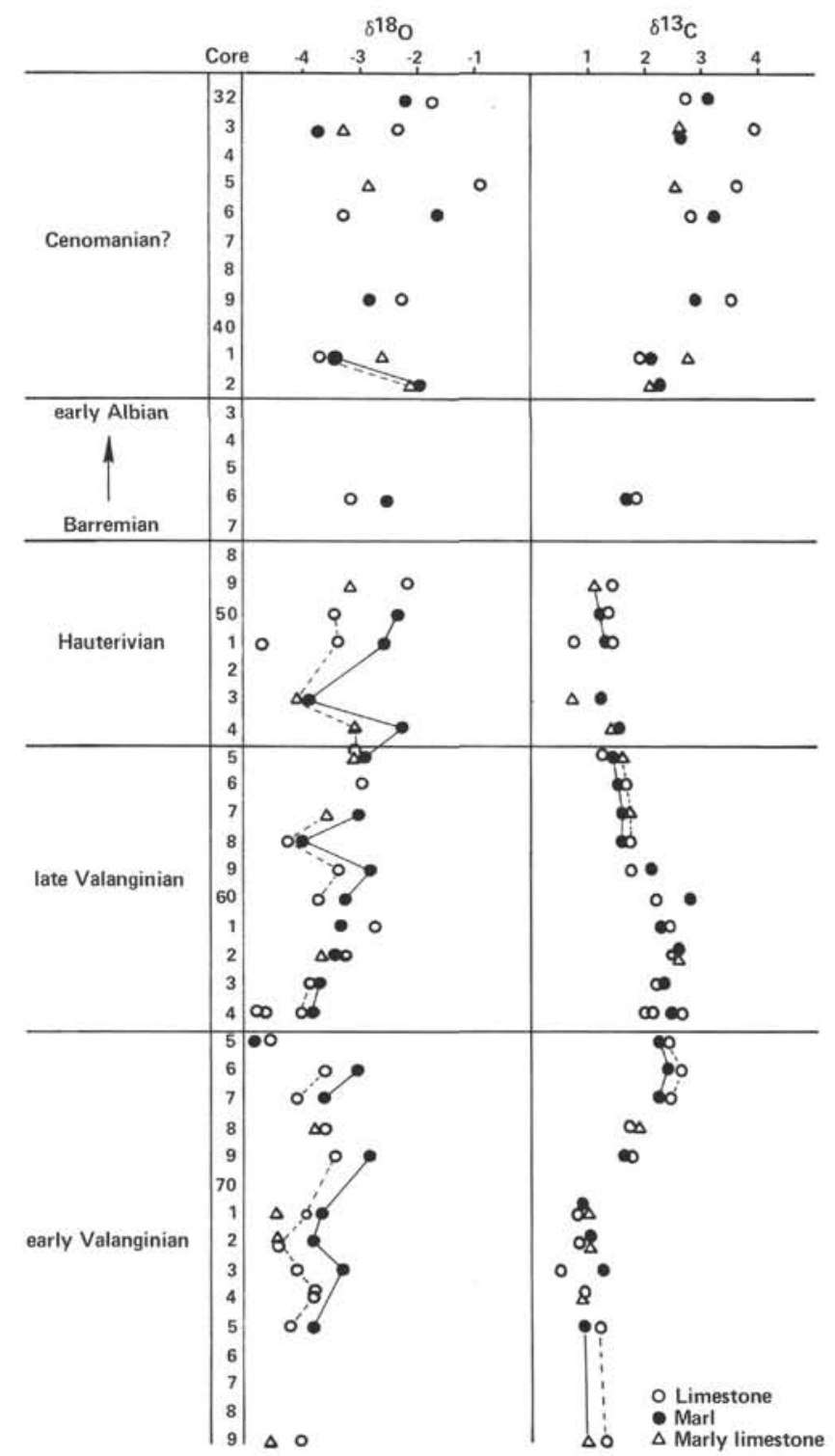

Figure 18. Distribution of ${ }^{18} \mathrm{O}$ and ${ }^{13} \mathrm{C}$ isotopes through the Cretaceous sequence at Hole 535. Solid (marl) and dashed (limestone) lines outline continuities of the same trend: $\delta^{18} \mathrm{O}$ limestone lower than $\delta^{18} \mathrm{O}$ marl, or $\delta^{13} \mathrm{C}$ marl lower than $\delta^{13} \mathrm{C}$ limestone. $\delta$ expressed in \%o versus PDB standard.

an(?) at Site 535 show a negative correlation. This agrees with the negative correlation generally observed between sedimentation rates and intensity of burrowing. Besides, parallel trends at some levels of the curves prove that minor cyclicity is certainly not masked by burrowing (Figs. 27 and 28).

Major and minor cycles curves for the Cenomanian(?) (Site 535) and Albian (Site 540) also show a high range of fluctuation.

Asymmetry of cycles. Ternary cycles have been characterized by their asymmetry index. According to the terminology proposed in Figure 7, the index varies from 0 to 1 . A symmetric cycle has a value of 0.5 .

We calculated asymmetry index for the major cycles of each core (of intervals of $15 \mathrm{~m}$ for Angles) and drew curves of their vertical variations (Figs. 29-30). Like the

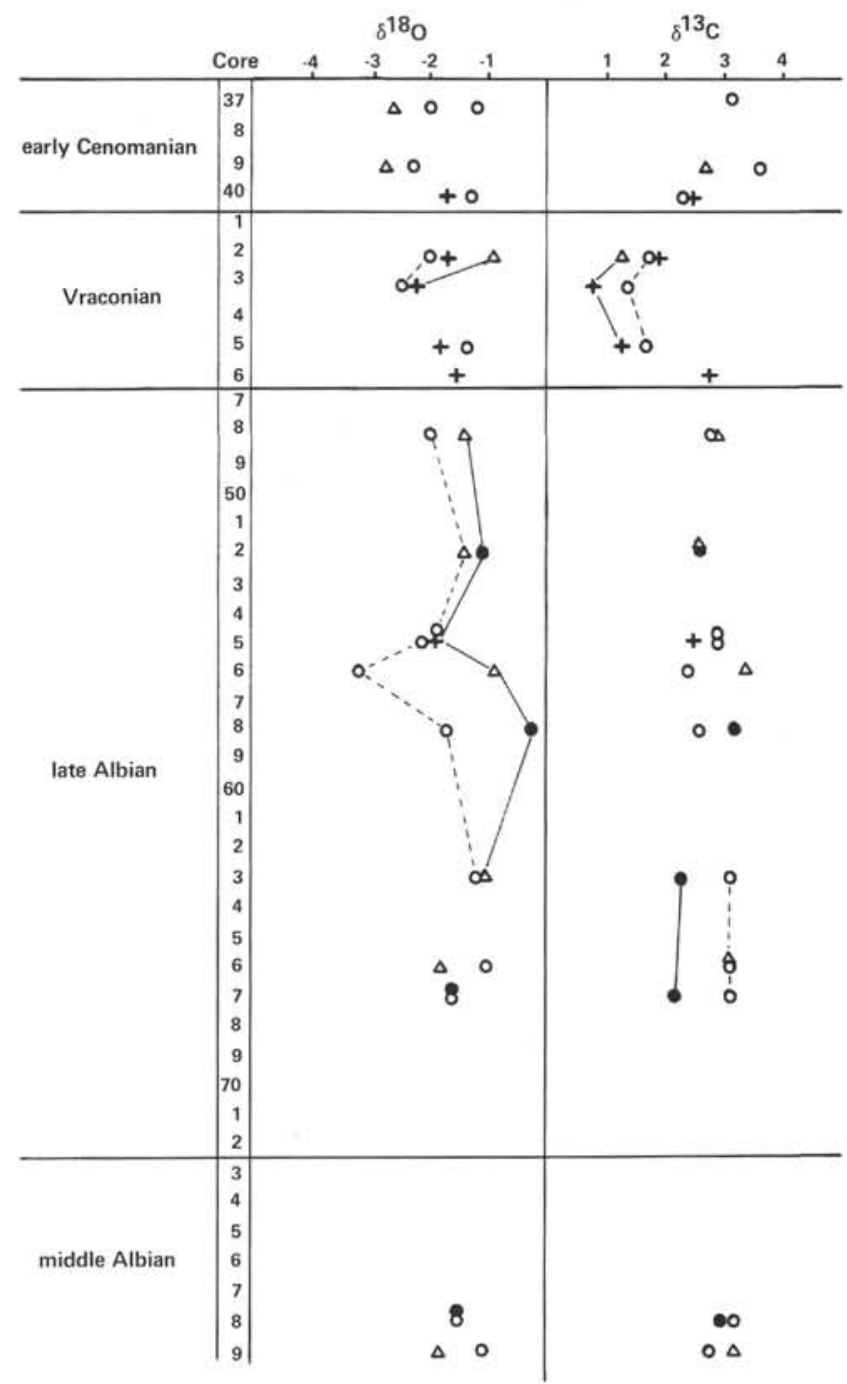

Figure 19. Distribution of ${ }^{18} \mathrm{O}$ and ${ }^{13} \mathrm{C}$ isotopes through the Albian and lower Cenomanian at Hole $540 .+$ is clayey limestone; see Figure 18 for other symbols. Solid (marl) and dashed (limestone) lines outline continuities of the same trend: $\delta^{18} \mathrm{O}$ limestone lower than $\delta^{18} \mathrm{O}$ marl, or $\delta^{13} \mathrm{C}$ marl lower than $\delta^{13} \mathrm{C}$ limestone. $\delta$ expressed in \%o versus PDB standard.

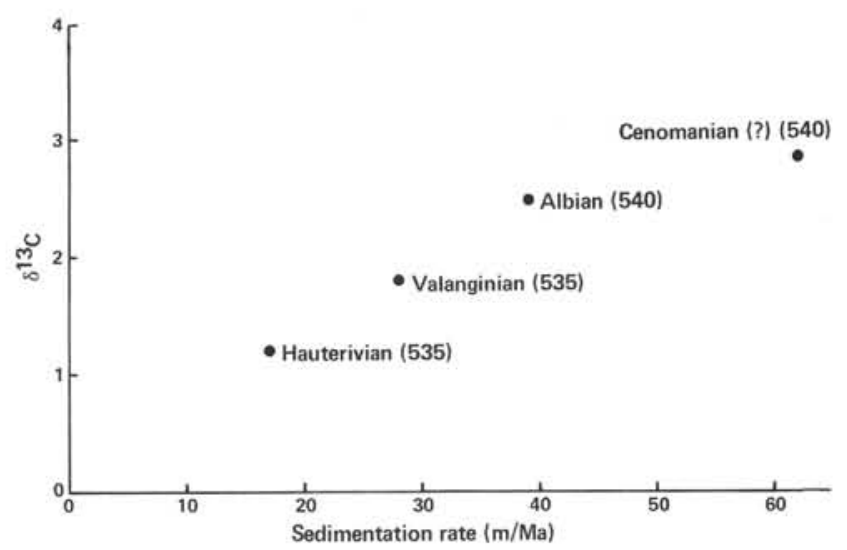

Figure 20. Average $\delta^{13} \mathrm{C}$ versus sedimentation rate for several stratigraphic intervals at Sites 535 and $540 . \delta$ expressed in \%o versus PDB standard. 


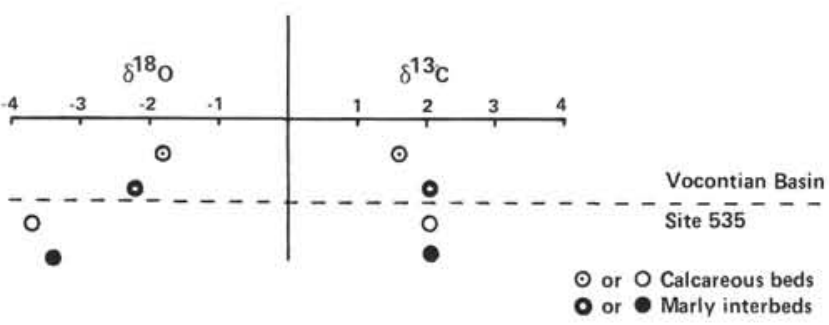

Figure 21. Average content of heavy $\mathrm{C}$ and $\mathrm{O}$ isotopes in upper Valanginian at Site 535 and in the Vocontian Basin. $\delta$ expressed in \%o versus PDB standard.

curves in Figures 25-28, these also reveal some largescale variations. For the Valanginian, global variations are nearly opposite at Sites 535 and 534; they are rather similar at Site 535 and Angles-Vergons, despite an incomplete curve for this last site. Curves are comparable for the Hauterivian of the three sites (taking into account the hiatus at the top of the Hauterivian sequence at Site 535, see Stratigraphic Implications section).

Asymmetry index is generally not as available for the correlations as is the frequency of cycles. The mean index calculated for each stage at each site (Table 2) is less than 0.5 , indicating that the limestones in a cycle show a more rapid transition to marly limestone upward than downward. This result is consistent with the distribution of organic carbon throughout the alternating cycles (Herbin et al., this vol.). Moreover, several authors have discussed the same type and sign of asymmetry [Dean et al., $(1978,1981)$ in Tertiary cycles off the coasts of northwest Africa; Arthur (1979) in North Atlantic Neocomian cycles; and Kauffman (1982) in limestone-shale rhythms in the Cretaceous of North America]. But McCave (1979) described asymmetries with opposite signs in Albian cycles of the western North Atlantic.

We must finally mention that the values of asymmetry plotted in Table 2 are negatively correlated with the sedimentation rates (Fig. 31). Thus the curves of asymmetry-index variations are expected to express the fluctuations of the sedimentation rate, as do the curves of minor cycles, but in the opposite way. Actually, the two kinds of curves often show opposite trends, particularly for Site 534 .
Variation of cycle thickness: cyclograms, harmonic analysis. Cyclograms illustrate the thickness variation with time of major cycles (Fig. 32). The latter are represented at each site by equidistant segments perpendicular to a vertical axis, the lengths of which are proportional to each cycle thickness. Some biostratigraphic boundaries have been added along the axis.

Variation of cycle thicknesses is cyclic itself (megacycles), but these changes are interrupted by many discontinuities. These variations, together with a biostratigraphic control, form the basis of the "cyclostratigraphic" correlations we propose between the three sites.

The main elements used for the correlations are the following: (1) general evolution of the thickness for bedinterbed cycles (long, isolated cycles, which are frequent in series rich in thick limestone beds-Site 535, AnglesVergons-not taken into account); (2) discontinuities, previously noted, and particularly their type, frequencies, and situation along the sections; (3) particular groups of bed-interbed cycles; for instance, cycles with similar length following each other; and (4) proportions and distribution of long cycles with regard to short ones.

Accompanying the cyclograms for Sites 535 and 534 is a mention of the interval corresponding to the "faisceau du Toulourenc," the Vocontian marker sequence quoted previously (see Geochemistry section).

Based on these criteria, plus the biostratigraphic boundaries, we propose certain ties among Angles-Vergons, Site 534, and Sites 535 and 540. These ties are shown on the three cyclograms (Fig. 32).

Considering the large-scale trends and the thickness of bed-interbed cycles, we have divided the sections into correlatable cyclozones:

Cyclozone 1 (Thurmanniceras otopeta and [part of] T. pertransiens Biozones), well-developed megacycles.

Cyclozone 2 ( $T$. pertransiens and [part of] T. campylotoxum Biozones), alternation of sequences with many and with few discontinuities.

Cyclozone 3, fluctuating evolution broken by discontinuities, Subzone 3a (top of T. campylotoxum Biozone), long bed-interbed cycles not composing very thick sets (two to three units generally); Subzone 3b (nearly the whole upper Valanginian), long bed-interbed cycles composing important sets (10 to 40 units).

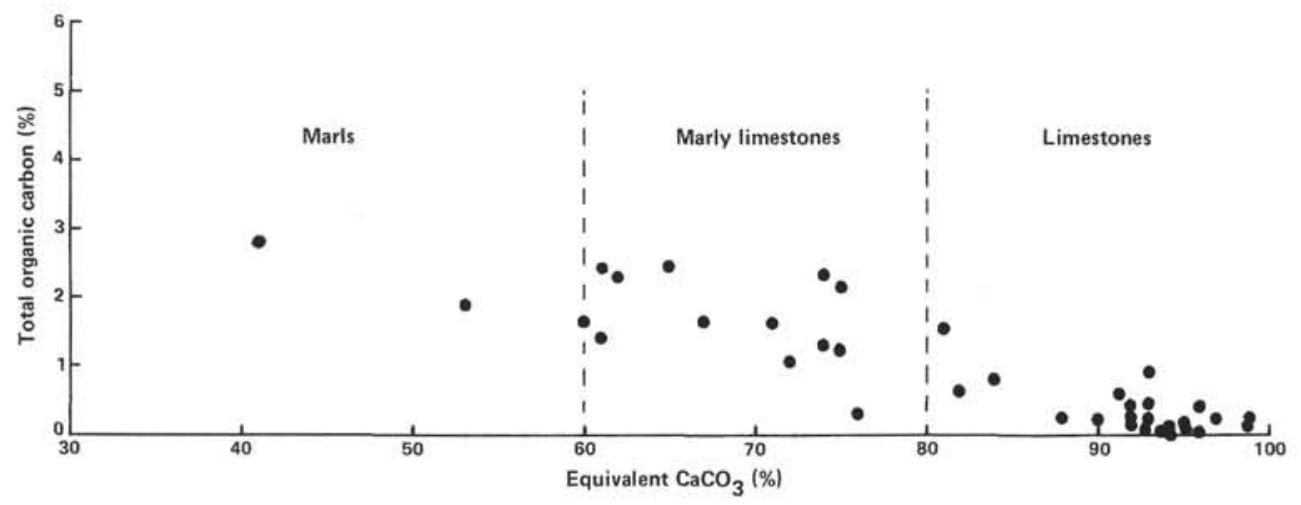

Figure 22. Correlation between total organic carbon content and lithologic types at site 535 shown by equivalent $\mathrm{CaCO}_{3}$ percentages. (Analyses of samples was done by G. Deroo and J.-P. Herbin.) 


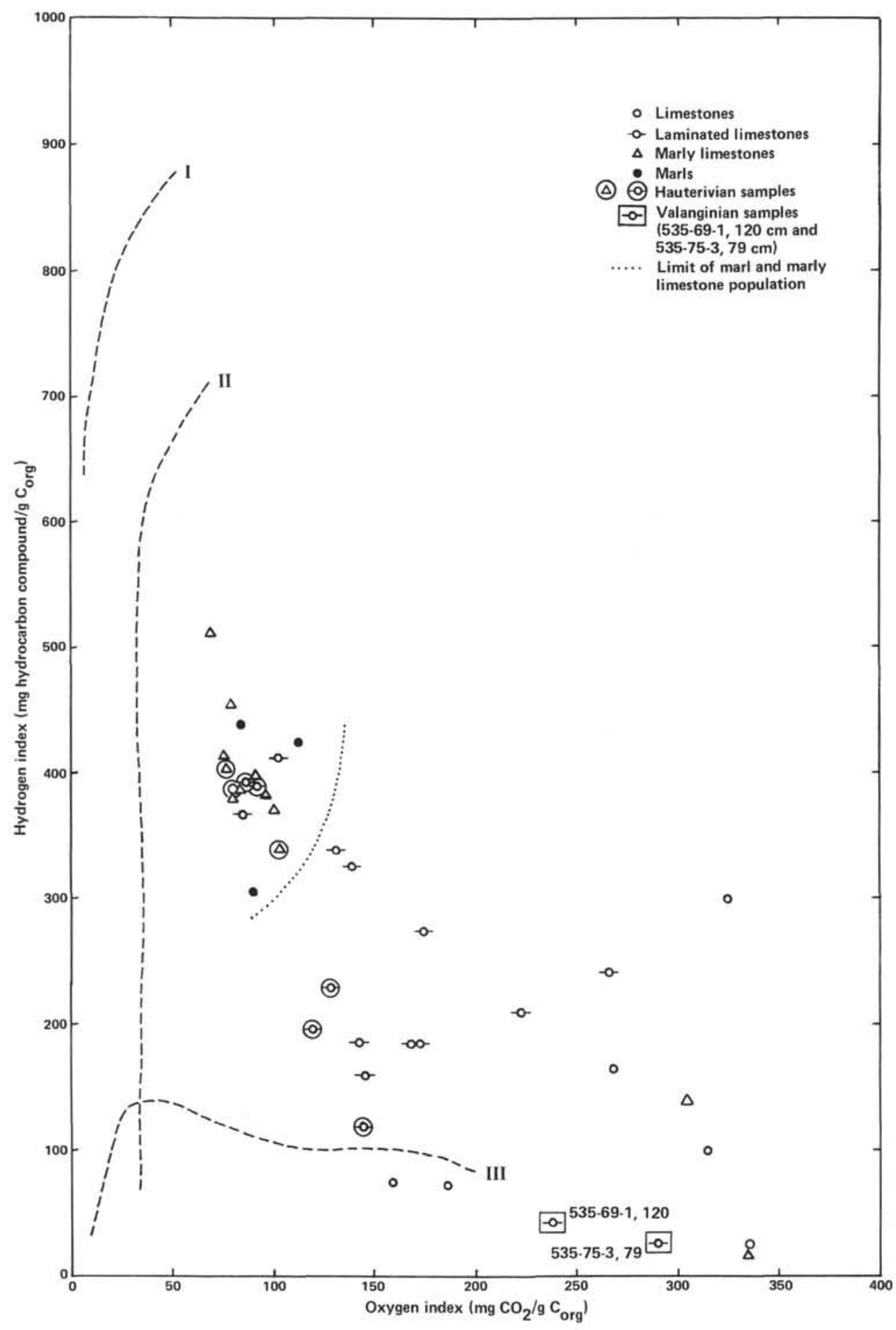

Figure 23. Characterization of organic matter by pyrolysis assay for the Neocomian at Site 535. Hydrogen versus oxygen index (van Krevelen diagram; analyses of samples was done by G. Deroo and J.-P. Herbin).

Cyclozone 4 (uppermost Valanginian and a large part of the Hauterivian), like Cyclozone 2.

Cyclozone 5, like Cyclozone 3.

We have drawn histograms (Fig. 33) showing lengths (expressed as numbers of constitutive bed-interbed cycles) of megacycles. The distributions are generally polymodal. A megacycle commonly consists of 4 to $6 \mathrm{cy}-$ cles, less commonly of 5 (approximate durations from
65,000 to 100,000 yr.). Parallel evolution of cycle thickness in different sites is also shown by harmonic analysis. We adapted the program proposed by Davis (1973) for a microcomputer (HP85) and used only the minor cycles, because their thickness determinations are easier than those for the major ones. The computation concerned 672 cycles for Site 534 (Cores 67 to 79) and 651 cycles for Site 535 (Cores 58 to 71). They all belong to 
Table 2. Major characteristics of alternating cycles at four sites: 534, 535, 540, and Angles-Vergons.

\begin{tabular}{|c|c|c|c|c|c|c|c|c|c|c|c|}
\hline \multirow[b]{2}{*}{$\begin{array}{l}\text { Site and } \\
\text { age }\end{array}$} & \multirow[b]{2}{*}{$\begin{array}{l}\text { Thickness } \\
\text { (m) }\end{array}$} & \multirow[b]{2}{*}{$\begin{array}{l}\text { Sedimentation } \\
\text { rate }(\mathrm{m} / \mathrm{Ma})\end{array}$} & \multicolumn{5}{|c|}{ Major cycles } & \multicolumn{4}{|c|}{ Minor cycles } \\
\hline & & & Observed & $\begin{array}{l}\text { Calculated } \\
\text { for a full } \\
\text { recovery }\end{array}$ & $\begin{array}{l}\text { Mean } \\
\text { length } \\
(\mathrm{m})\end{array}$ & $\begin{array}{l}\text { Mean } \\
\text { duration } \\
\text { (yrs.) }\end{array}$ & Asymmetry & Observed & $\begin{array}{l}\text { Calculated } \\
\text { for a full } \\
\text { recovery }\end{array}$ & $\begin{array}{c}\text { Mean } \\
\text { length } \\
(\mathrm{m})\end{array}$ & $\begin{array}{c}\text { Mean } \\
\text { duration } \\
\text { (yrs.) }\end{array}$ \\
\hline \multicolumn{12}{|l|}{ Site 535} \\
\hline Cenomanian(?) & 237.5 & 30 & 479 & 645 & 0.36 & 12,250 & 0.39 & 1283 & 1688 & 0.14 & 4,700 \\
\hline Hauterivian & 59.5 & 17 & 103 & 133 & 0.44 & 26,000 & 0.47 & 232 & 296 & 0.20 & 10,750 \\
\hline Valanginian & 195 & 27.85 & 339 & 440 & 0.44 & 16,000 & 0.40 & 958 & 1222 & 0.16 & 5,800 \\
\hline \multicolumn{12}{|l|}{ Site 540} \\
\hline Albian & 370.5 & 39 & 341 & 931 & 0.39 & 10,000 & 0.32 & 746 & 2285 & 0.16 & 4,100 \\
\hline \multicolumn{12}{|l|}{ Site 534} \\
\hline Hauterivian & 99 & 19.8 & 158 & 302 & 0.32 & 16,500 & 0.48 & 317 & 578 & 0.17 & 8,650 \\
\hline Valanginian & 153 & 21.85 & 395 & 443 & 0.34 & 15,800 & 0.44 & 896 & 1004 & 0.15 & 7,000 \\
\hline \multicolumn{12}{|l|}{ Angles-Vergons } \\
\hline Hauterivian & 178 & 35.6 & 232 & 247 & 0.72 & 20,250 & 0.34 & & & & \\
\hline Valanginian & 242 & 34.5 & 413 & 438 & 0.58 & 16,000 & 0.32 & & & & \\
\hline
\end{tabular}

Note: Geochronologic scale used is from Kennedy and Odin (1982). Thicknesses of Valanginian and Hauterivian at Site 535 take into account the correlations proposed between the sequence at Site 535 and Angles-Vergons (see Statistical Analysis section).

Table 3. Examples of limestone-marl cycle durations in pelagic Early and middle Cretaceous.

\begin{tabular}{|c|c|c|c|}
\hline Location & Age & $\begin{array}{c}\text { Duration } \\
\text { of cycles } \\
\text { (thousands } \\
\text { of yr.) }\end{array}$ & Authors \\
\hline $\begin{array}{l}\text { Site } 367 \text { (Cape Verde } \\
\text { Basin) }\end{array}$ & Early Cretaceous (Core 26) & 37 & Dean et al., 1978 \\
\hline $\begin{array}{l}\text { Site } 463 \text { (mid-Pacific } \\
\text { mountains) }\end{array}$ & late Aptian to early Albian & $14-38$ & Ferry et al,, 1981 \\
\hline $\begin{array}{l}\text { Sites } 386 \text { and } 387 \text { (west- } \\
\text { ern North Atlantic) }\end{array}$ & Albian & 17 and 20 & McCave, 1979 \\
\hline $\begin{array}{l}\text { Sites } 399 \text { and } 400 \text { (Bay } \\
\text { of Biscay) }\end{array}$ & $\begin{array}{l}\text { Albian } \\
\text { Aptian }\end{array}$ & $\begin{array}{l}36-44 \\
21-29\end{array}$ & $\begin{array}{l}\text { Montadert, Rob- } \\
\text { erts, et al., } \\
1979\end{array}$ \\
\hline $\begin{array}{c}\text { Site } 398 \text { (North } \\
\text { Atlantic) }\end{array}$ & Aptian-Albian & $30-100$ & Arthur, 1979 \\
\hline $\begin{array}{l}\text { Western Interior, USA } \\
\text { Umbria (Italy) }\end{array}$ & $\begin{array}{l}\text { Cretaceous } \\
\text { middle Cretaceous }\end{array}$ & $\begin{array}{c}30-50 \\
23.4\end{array}$ & $\begin{array}{l}\text { Kaufmann, } 1982 \\
\text { de Boer, } 1982\end{array}$ \\
\hline
\end{tabular}

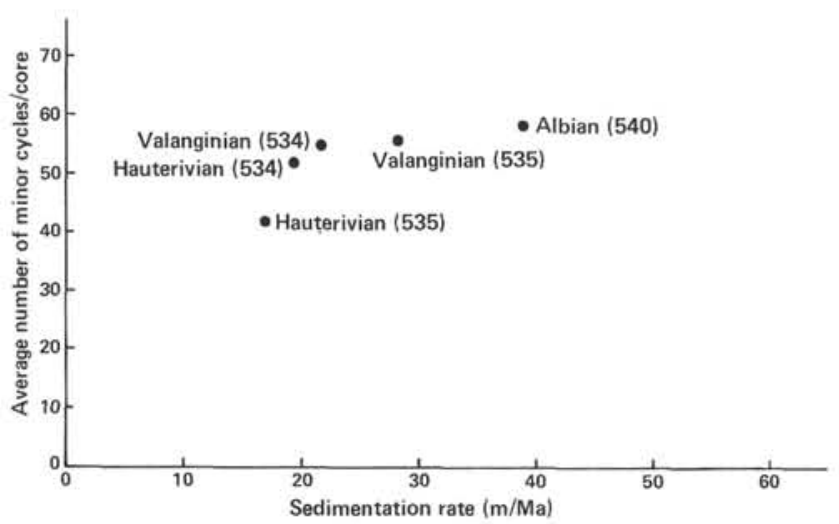

Figure 24. Correlation between the average number of minor cycles per core, calculated for some stratigraphic intervals at Sites 534, 535 , and 540, and the sedimentation rate.

the same Valanginian interval, which is also the best recovered.

Harmonic analysis must be based on measurements equally spaced in time or space; we have no proof that this is true here. However, our first goal was to compare the two sections, not to determine the duration of the different components or the harmonics of them.

The list below summarizes the results expressed as "number of cycles." A certain similarity between the two series is evident. So, we can say that deposition of the two series probably reflects the same periodicities.

\begin{tabular}{ll}
\hline Site & Site \\
534 & 535 \\
\hline 29 & 26 \\
& 11 \\
& \\
8.1 & \\
6.7 & 6.5 \\
4.8 & 4.5 \\
& 4.2 \\
3.7 & 3.5 \\
& 3.3 \\
2.7 & 2.8 \\
2.4 & 2.5 \\
2.1 & 2.2 \\
2 & 2 \\
\hline
\end{tabular}

\section{Stratigraphic Implications of Cycle Correlation}

clicity (frequency, asymmetry, and thickness of bed-interbed cycles) improve notably the stratigraphy of the Neocomian at oceanic sites.

1. The lower/upper Valanginian and Valanginian/ Hauterivian boundaries, which are, at best, only approximately fixed at Site 535 (Buffler et al., this vol.), may be set up more accurately by cyclograms. The first boundary is situated at the bottom of Core 64 , thus more nearly the top of the calpionellid Zone E than in the Angles series. The second (higher than supposed) is in the lower part of Core 54.

2. The biozonation of Angles parastratotypic succession has been applied to the Valanginian of Sites 534 and 535 . 


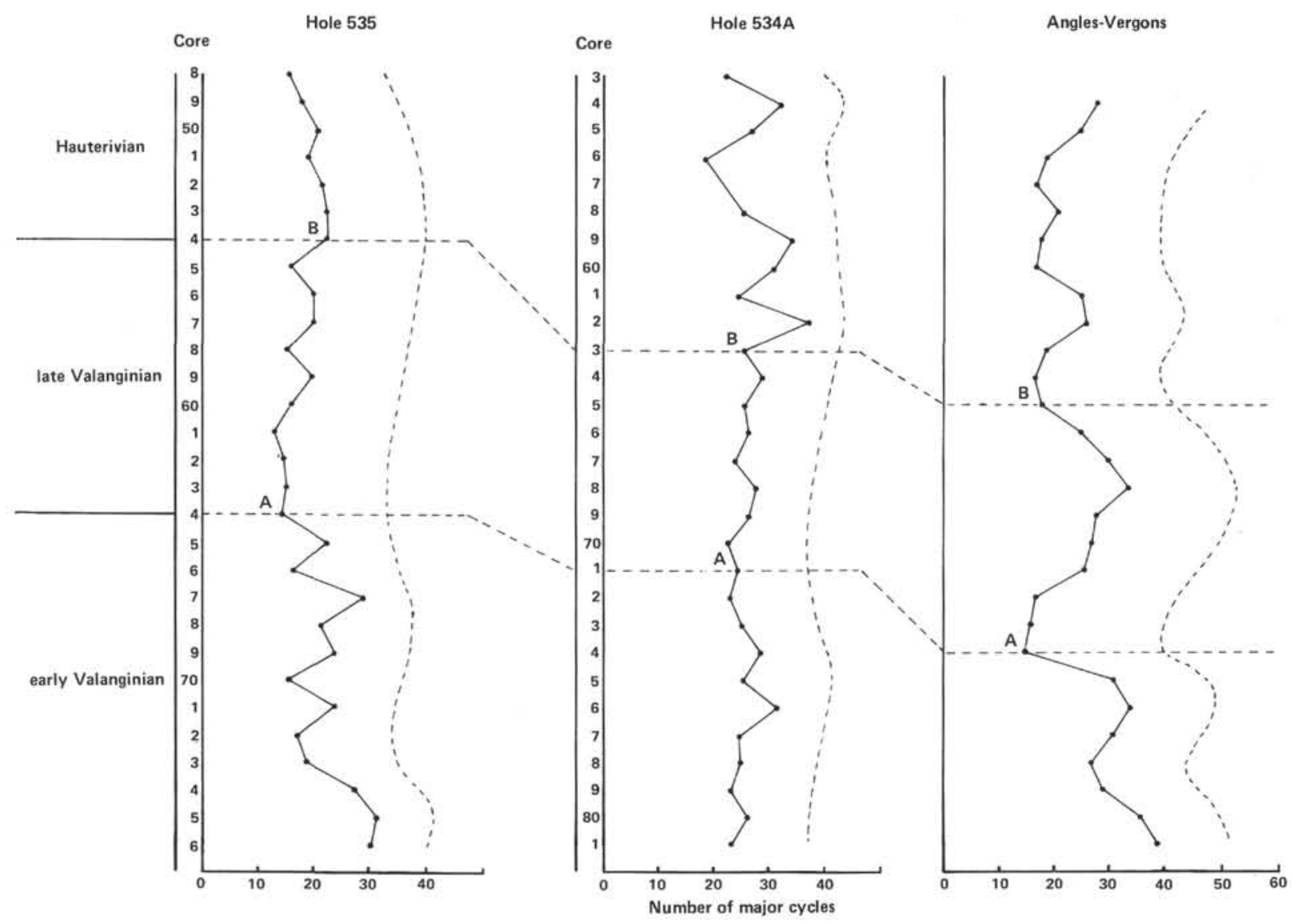

Figure 25. Variations in the number of major cycles per core (Holes 535 and 534A) or per $15 \mathrm{~m}$ of deposit (Angles-Vergons) across Valanginian-Hauterivian interval. A and B are two correlated trend reversals. Horizontal dashed lines are stratigraphic boundaries. Vertical dashed lines are smoothed curves to facilitate comparisons.

3. A hiatus corresponding approximately to three cores is observed on top of the Hauterivian. This gap is shown in the cyclograms but also indicated by a comparison of minor-cycle and major-cycle asymmetry curves for Sites 534 and 535 (Figs. 27 and 29). It precedes the gap or condensation affecting the lower Barremian (Buffler et al., this vol.).

4. Another condensation or gap is indicated between Core 60 and Core 62 at Site 535 by cyclograms for Site 535 and Angles-Vergons.

5. Comparison of the minor-cycle curves suggests that the Valanginian/Hauterivian boundary at Site 534 should be located further uphole (Cores 63 to 62).

6. According to major-cycle curves, the Cenomanian(?) of Site 535 and Albian of Site 540 would probably overlap. Indeed, Cores 535-25 to 535-36 seem to correlate with Cores 540-26 to 540-36 (Fig. 26). Using other means, Debrabant and others (this volume) reach the same conclusion.

\section{General Features of Bed-Scale Cycles}

The number of major bed-scale cycles proceeding from limestone-marl alternations is fairly comparable in the Valanginian of the three studied series, in spite of the lithologic differences previously noted. For the Hauterivian, a notable difference in the recovery at the two oceanic sites may be the cause of the variability of these numbers. The cycles are 20,000-25,000 yr. long for Hauterivian, nearly 16,000 yr. long for Valanginian. The mean asymmetry of cycles is always below 0.5 (i.e., the calcareous unit in the cycle appears generally more abruptly than it disappears). The sedimentation rate for a given interval is negatively correlated with the mean asymmetry index and positively correlated with the minor-cycle frequency.

Frequency, asymmetry, and thickness variations of limestone-marl cycles through the Valanginian-Hauterivian and Albian intervals are megacyclic. Some parallel trends are observed at the three sites, as shown in the cyclograms. They lead to detailed correlations between the three sites (for the Lower Cretaceous), then to an improved stratigraphic subdivision and to a perception of stratigraphic gaps. One of them, situated in uppermost Hauterivian, has been already noted along western Africa continental margin (Pflaumann and Cepek, 1982).

\section{Small-Scale Alternations at Sites $\mathbf{5 3 5}$ and $\mathbf{5 4 0}$}

\section{Banding}

This rhythmicity appears as a succession of alternating dark and light-colored bands, several millimeters or a few centimeters thick. Generally, banding is superim- 


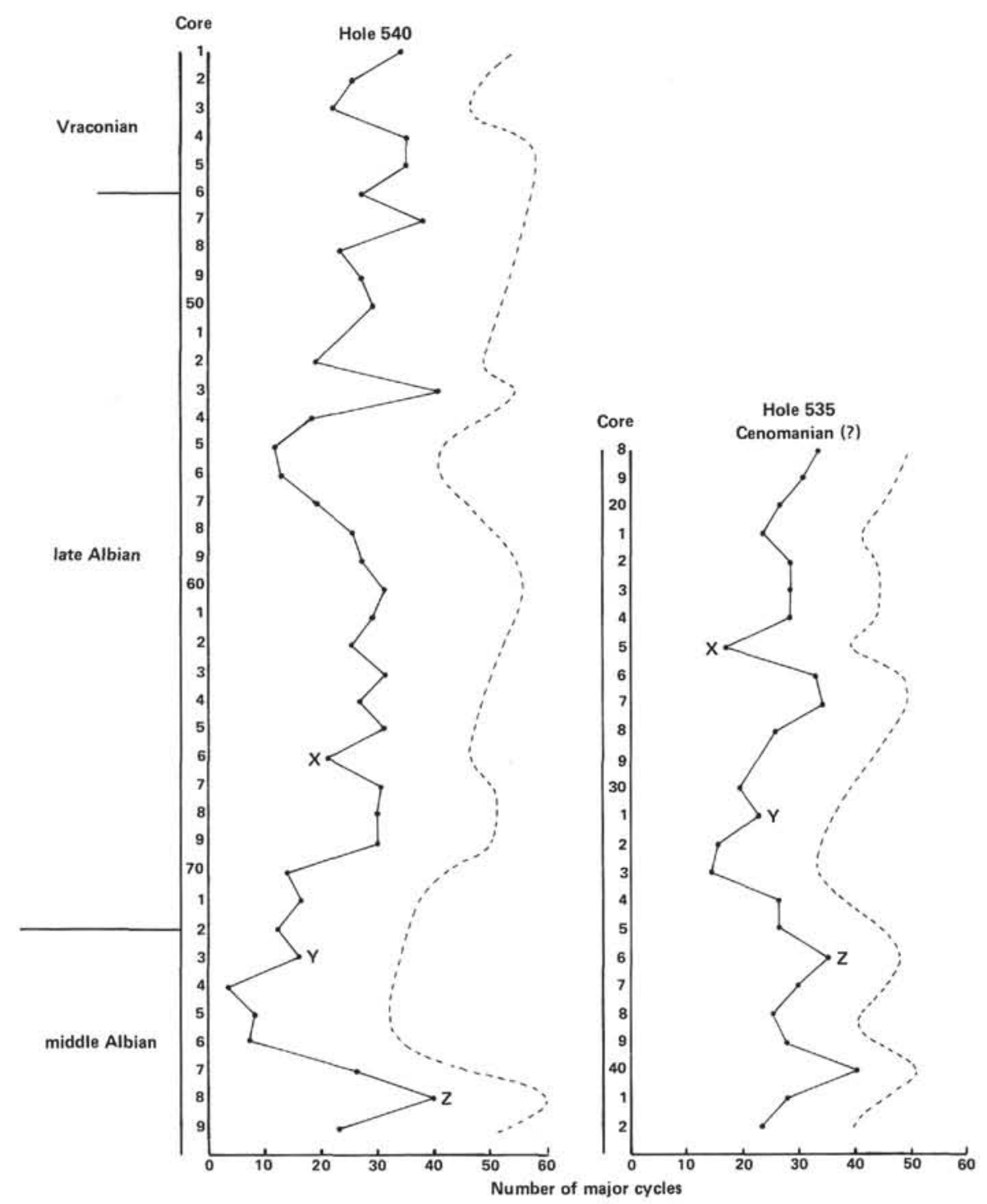

Figure 26. Variations in the number of major cycles per core [Albian at Hole 540, Cenomanian(?) at Hole 535]. X, Y, and Z are possible correlated points. Dashed lines are smoothed curves to facilitate comparisons.

posed on bed-interbed cycles, already defined, but it may be absent [Site 535, Cores 30, 3536,38 (part), 46, and 47]. Bands, in turn, are composed of sets of dark and light-colored laminae, but there are homogeneous bands that represent either a thick lamina or a bundle of several weakly visible laminae of identical composition (Fig. 34). As the sets of laminae form banding, sets of bands form bed-scale alternations of limestone and marl noted before.

The most calcareous bands may be skeletal (with benthic debris), homogeneous micrite, layers richer in calcareous plankton (foraminifers, nannofossils), or layers of rhombic dolomite crystals. The dark bands are the most clayey but also contain more pyrite, organic matter, phosphate, quartz, and mica than the light-colored bands. Contact between bands may be plane, irregular, or sometimes stylolitic. The proportions of light-colored and dark bands are quite variable.

\section{Lamination}

Laminations form the background alternation within all the lithologic facies encountered in cores and are generally a millimeter or less in thickness. At Site 535, we observed laminae of skeletal debris deposited by traction-currents. These units are $0.070-1 \mathrm{~mm}$ thick and irregular; they sometimes have a ripple structure. In Cores 535-23 to 535-28, traction-current laminae coexist with other units that may be autochthonous. The latter form cycles 30-350 $\mu \mathrm{m}$ thick, with an alternation of (1) lightcolored micrite, abundant foraminifers, radiolarians, and pelagic pelecypods and (2) dark micrite with more clay, iron oxide, and organic matter. Evidence for traction- 


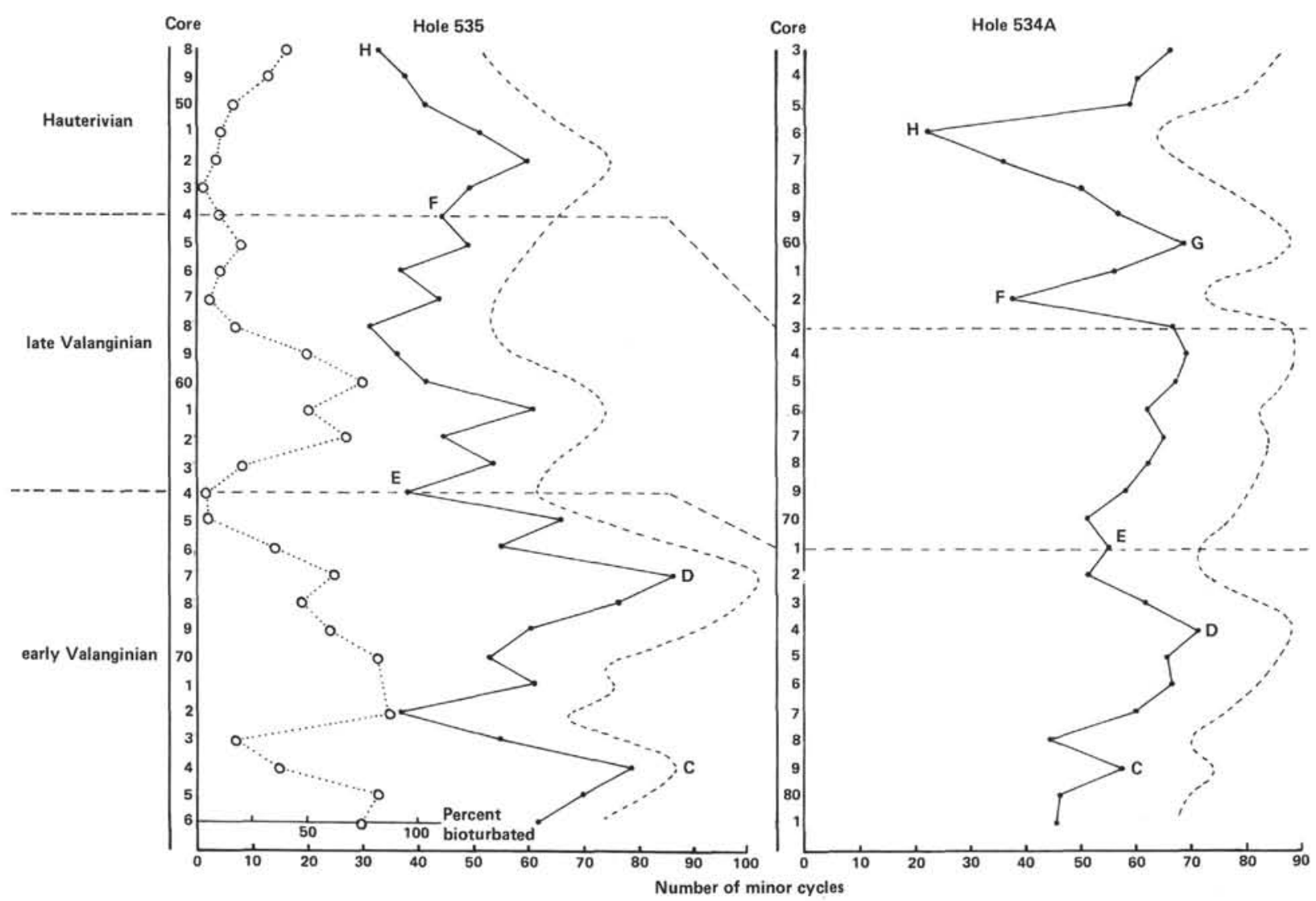

Figure 27. Variations in the number of minor cycles per core across Valanginian-Hauterivian interval at Holes 535 and 534A. Degree of bioturbation at Site 535 shown by percentages of burrowed sections in cores (dotted line). $\mathrm{C}$ to $\mathrm{H}$ are correlated points of the minor cycle curves. Horizontal dashed lines are stratigraphic boundaries. Vertical dashed lines are smoothed curves to facilitate comparisons.
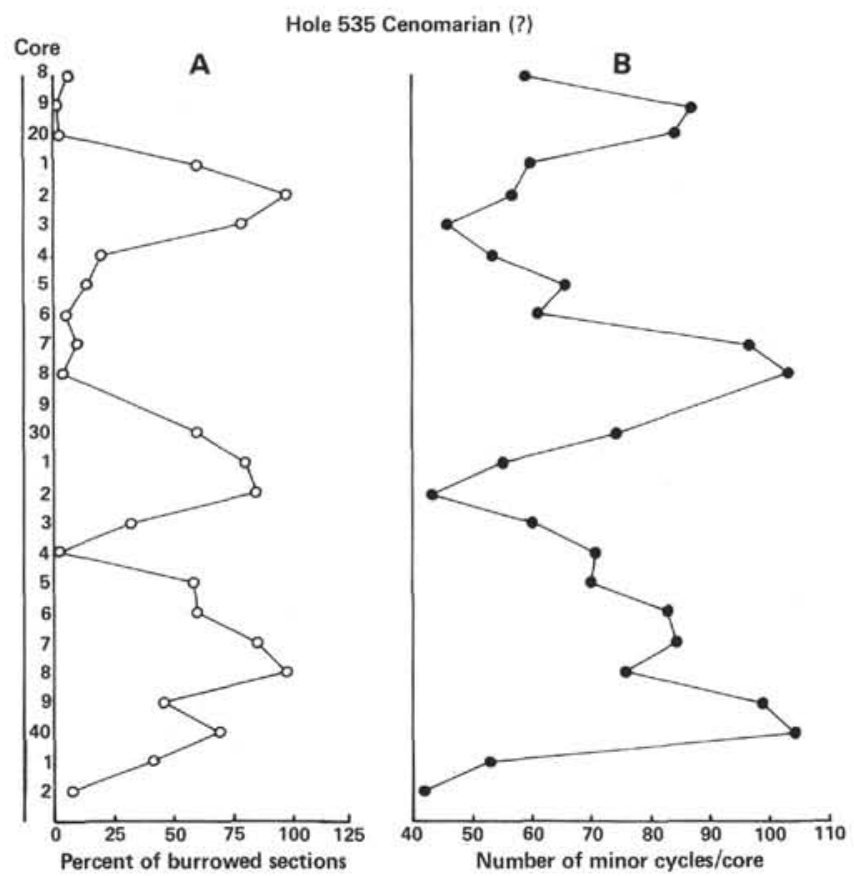

Figure 28. Hole 535, Cenomanian(?). A. Degree of bioturbation (percentages of burrowed sections in cores). B. Variations in the number of minor cycles per core, expressing the variations in sedimentation rate. current is again found in Cores 535-75 through 535-78. In Cores 535-42 through 535-74, we observed an alternation of more calcareous light-colored laminae and darker laminae in which clay and organic matter are concentrated.

The laminations belong to three orders of scale at least. The first order (often destroyed and deformed by compaction) corresponds to cycles $0.008-0.025 \mathrm{~mm}$ thick (Fig. 35) with thin dark laminae (concentration of iron oxide and clay) and larger light-colored laminae (concentration of nannofossils) (Fig. 36). In some layers, the calcareous laminae grow into ovoid white specks, welloutlined and often aligned, which are accumulations of well-preserved nannofossils (Figs. 37 and 38). The pelletic nature of these specks has been assumed by several authors. They correspond certainly to the "stringers of white specks" observed in Aptian-Albian laminated marls of the Central Atlantic (Donnelly, Francheteau, et al., 1980). In higher orders of laminations (Fig. 39), lightcolored, calcareous units, $0.05-1 \mathrm{~mm}$ thick, may be groups of flattened white pelletic(?) specks (in marls) (Fig. 37A) or groups of lens-shaped amygdaloid and unraveled micritic areas, separated by a thin brown argillaceous film (in marly and argillaceous limestones) (Fig. 40). Dark clayey units, $0.010-1 \mathrm{~mm}$ thick or more, contain more organic matter, fish debris, iron oxide, detrital quartz, and mica. Coccolites are the most frequent among planktonic calcareous remains. 


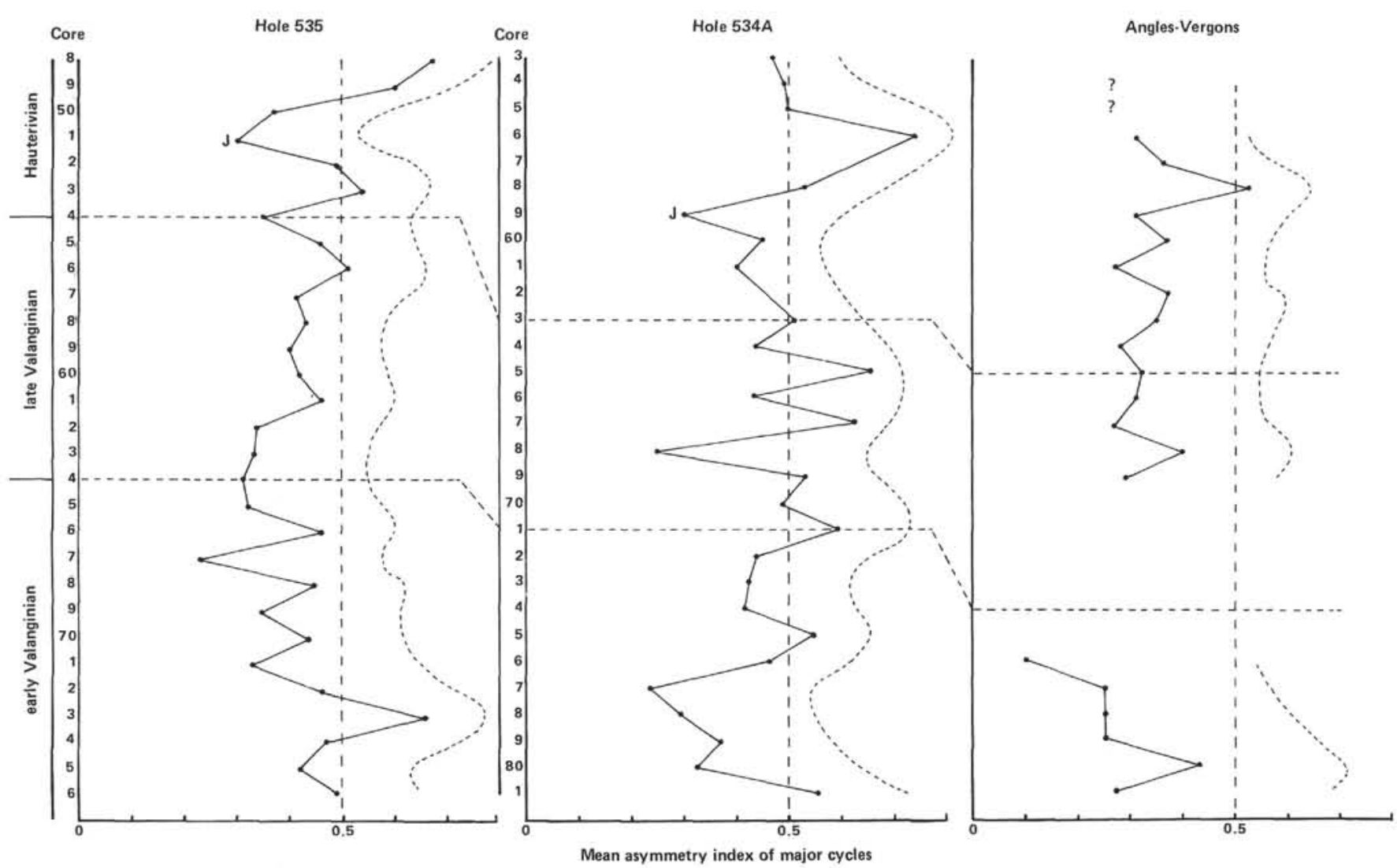

Figure 29. Variations in Valanginian and Hauterivian average asymmetry indexes of major cycles either per core (Holes 534A and 535) or per $15 \mathrm{~m}$ of sediment (Angles-Vergons) across Valanginian-Hauterivian interval. J marks a possible correlation point. Horizontal dashed lines are stratigraphic boundaries. Vertical dashed lines are smoothed curves to facilitate comparisons.

In limestones, we assume that the lamination may be represented by parallel alignments of alternatively large and small radiolarians (Fig. 41).

The origin of micritic specks and of amygdaloid patches is problematic. They are either pellets, detrital elements, or the result of a disruption of continuous layers into microlenses by compaction (Figs. 40, 42). When specks are sparse and made of packed nannofossils, the pelletal origin is highly probable; but when these microlenses or specks are pressed on each other, deformed and stretched, they may be the result of a boudinage by compaction. A same constricted aspect, simulating a flaser-bedding structure, has been noticed by Jansa and others (1978) in the Cretaceous succession at Site 367 (Central Atlantic); by Lancelot, Winterer, and others (1980) in Paleocene sediments at Site 415 (eastern Atlantic off northwestern Africa); and by Thiede, Vallier, and others (1981) in Aptian-Albian deposits of the Central Pacific. Compaction is also responsible for stylolitic seams. Sometimes present between laminae in dark levels, these seams are outlined by black and concentrated organic matter.

The Albian at Site 540 shows the same small-scale alternations, albeit more often disturbed by burrowing or intercalations of allochthonous material. In limestones, the microplanktonic components are generally gathered in laminae; radiolarians are especially present, with more than $90-95 \% \mathrm{CaCO}_{3}$, in the sediment, and foraminifers occur in more clayey deposits. In marly limestones, constituted by an alternation of light-colored and dark laminae, planktonic foraminifers are essentially located in the latter (Fig. 43). Similar plankton-rich laminae have been mentioned by Jenkyns (1976) in the Aptian of South Pacific.

We attempted to estimate durations for the different orders of laminations, by use of sedimentation rates calculated at different levels of the bed-interbed cycles. Mean deposition times obtained for first-order, second-order, and third-order couplets are respectively $1.2,4$, and 16.3 yr. Considering the approximations used for calculation, we estimate that the first value fits with an annual cycle; the others, corrected in the same proportions, would be 3.3 and 13.6 yr., respectively. In the Valanginian at Site 534, a duration of $10-50$ yr. has been proposed for laminae of unspecified thickness (Sheridan, Gradstein, et al., 1983). At Site 391, in the same basin and for coeval sediments, Freeman and Enos (1978) counted 67 laminae per $\mathrm{cm}$ and deduced a duration of $6 \mathrm{yr}$. for the deposition of each unit.

\section{DISCUSSION}

As indicated above, much of the cyclicity encountered in Cretaceous deposits is very uniform in both southeastern France and the southeastern Gulf of Mexico, especially regarding the lithologic and microfaunal characteristics. But, some variables, like clays or $\mathrm{C}$ and $\mathrm{O}$ 

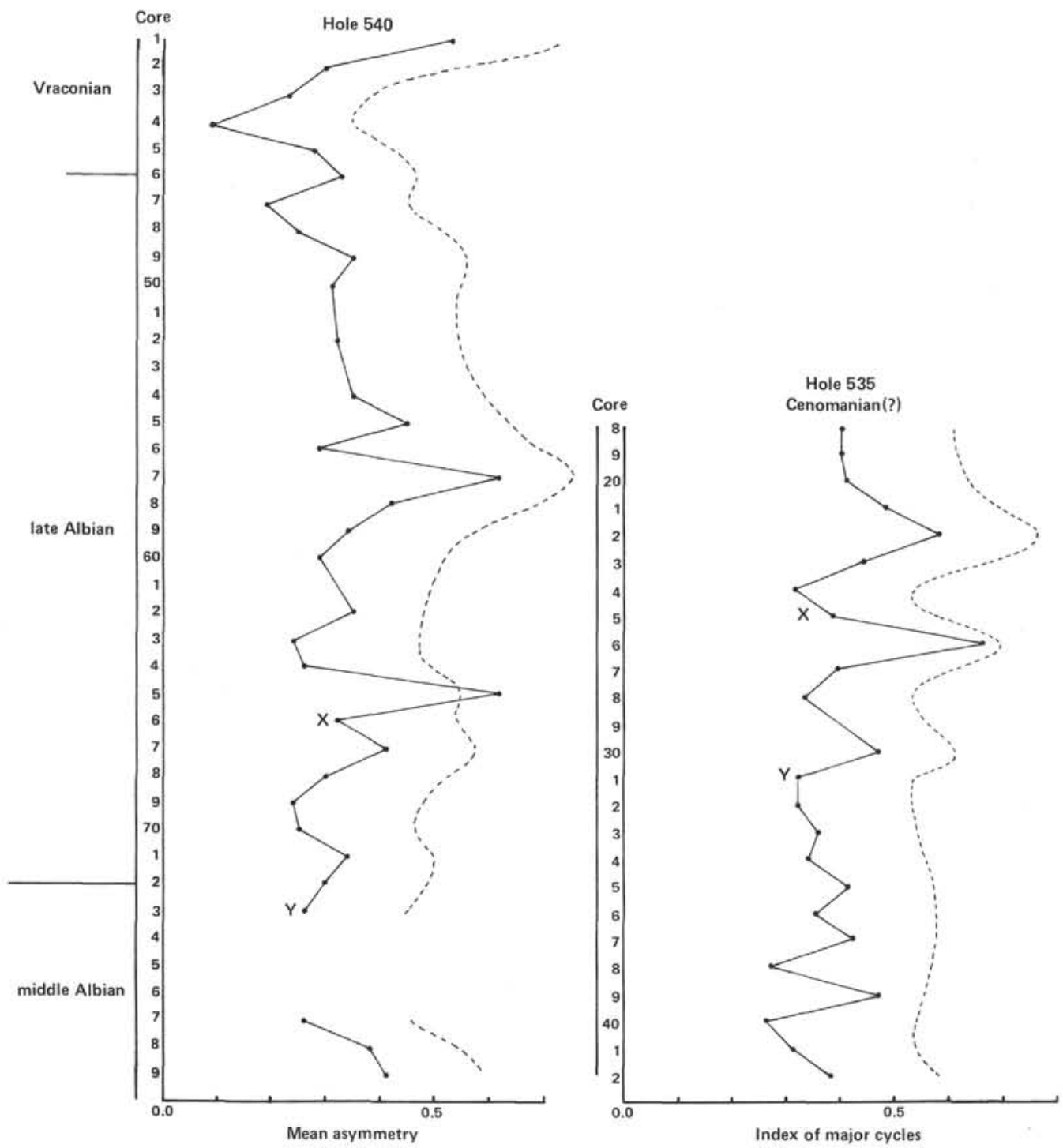

Figure 30. Variations in average asymmetry indexes of major cycles per core [Albian at Hole 540, Cenomanian(?) at Hole 535]. $\mathrm{X}$ and $\mathrm{Y}$ are possible correlation points. Dashed lines are smoothed curves to facilitate comparisons.

heavy isotopes, are different within the limestone-marl cycles at different sites. Local conditions may explain the differences.

The most conspicuous fact is the nearly worldwide correlations made possible by the cyclicity. During the Early Cretaceous, pelagic sedimentation cycles were governed by factor(s) beyond the scale of a single basin.

Before discussing global phenomena that may have controlled the alternating sedimentation, we have to differentiate, among all analysis data previously exposed, those corresponding to general causes and those related to local sedimentary or diagenetic events.

\section{Evidence for Overregional Control of the Cycles}

Bed-scale alternations. The fact that these cycles can be correlated over $5000 \mathrm{~km}$ in the Tethyan belt leads us to rule out gravity processes to explain limestone-marl alternations. We concluded similarly for Valanginian limestone-marl cycles of the Vocontian Basin (Cotillon et al., 1980). Nevertheless, the autochthonous alternating sedimentation may be affected and polluted by winnowings, redepositions, or skeletal sand supplies. These are widespread in Albian and Cenomanian(?) deposits of Sites 535 and 540 as well as in the Hauterivian at Site 534 , and they are the result of local events. But in spite of numerous detritic layers (graded siltstones and sandstones, debris flows) interfingered in the Hauterivian succession at Site 534 (Sheridan, Gradstein, et al., 1983), the deposits keep a basic alternating pattern, allowing accurate correlations between Sites 534 and 535 (Figs. 25 and 27). Therefore, intercalations of many redeposited layers in a pelagic alternating section do not necessarily indicate a fatal obliteration of its original cyclic constitution.

Lamination. Cretaceous laminated sediments are as widespread as bed-scale alternations in pelagic deposits of oceanic sites. According to their aspect, structure, shape, and possible association with graded detritic lay- 


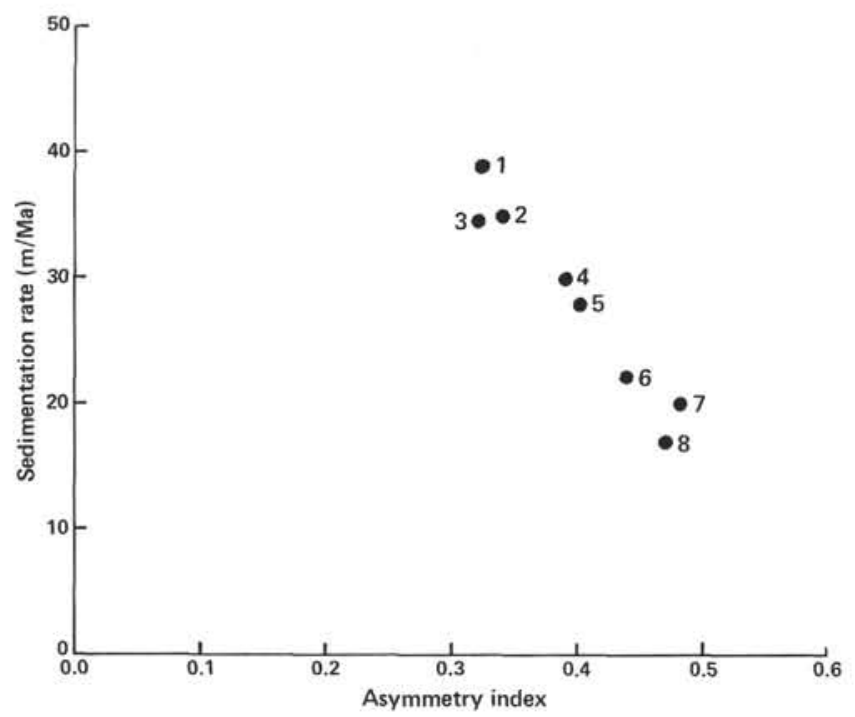

Figure 31. Mean asymmetry of major cycles versus sedimentation rates for some stratigraphic intervals. 1: Albian, Site 540; 2: Hauterivian, Angles-Vergons; 3: Valanginian, Angles-Vergons; 4: Cenomanian(?), Site 535; 5: Valanginian, Site 535; 6: Valanginian, Site 534; 7: Hauterivian, Site 534; 8: Hauterivian, Site 535.

ers, pelagic laminae of fine-grained sediments have been considered either as autochthonous deposits or as elements of distal turbidites (for the latter interpretation see particularly de Graciansky and Chenet, 1979; Montadert, Roberts, et al., 1979; Thiede, Vallier, et al., 1981).

If laminae and alternating beds constitute a background sedimentation resulting mainly from a vertical flux of particles, the former may be compared to the varvelike deposits described in the Black Sea Quaternary section (Ross and Degens, 1974; Ross, Neprochnov, et al., 1978); the Aptian-Albian deposits of the Central Atlantic (Donnelly, Francheteau, et al., 1980); and the Cretaceous of North America (Kaufmann, 1982). But a varvelike aspect and deposition do not necessarily imply an annual duration for the couplets of dark/light laminae.

The comparison with varves is straightforward when laminae are plane, parallel, and nannofossil rich and show well-preserved coccospheres, making improbable a significant horizontal transport of sedimentary particles on the sea bottom (Noël and Manivit, 1978). However, other examples need explanation.

Laminae containing remains of planktonic tests (foraminifers, radiolarians) are often viewed as resulting from a winnowing of Hedbergella or radiolarian oozes (Ryan, Hsü, et al., 1973; Leclaire, 1974; Cronan et al., 1974). However in our samples, an alternation occurs between laminae with abundant and often large radiolarians and laminae with small and scattered radiolarians (Fig. 41). In each of these units, calcitized radiolarians are unsorted and "float" in the micrite matrix. Sometimes, they still have their long, fine spines in connection; besides, radiolarians are often partially or totally replaced by pyrite, testifying to the connection of some organic matter to the siliceous 'skeletons at the beginning of burial. These characteristics make the transport by current rather un- likely. Alternation between periods of high and low terrigenous influx may explain the changes in radiolarian size; indeed, a positive correlation has been established in Vocontian Basin between the size of spheric radiolarians and $\mathrm{CaCO}_{3}$ content of deposits (Darmedru, 1982). Radiolarian layers of North Atlantic black shales were interpreted as plankton-bloom deposits by McCave (1979).

Laminae with pellets undoubtedly indicate sedimentation by current; indeed, pellets and varvelike laminae are exclusive mutually, the former being produced by a bioturbation that destroys delicate structures such as lamination. Besides, many pellet-bearing laminae are lenticular and formed by ripplets, particularly in the Cenomanian(?) and Albian at Sites 535 and 540.

The term "flaserlike" or "flasered" lamination has been used by some authors to characterize certain structures also described in this paper (Figs 40 and 42). Current-transport has been invoked by these authors. However, Lancelot, Winterer, et al. (1980) interpreted similar features as laminae deformed by diagenetic creep in the Paleocene of the eastern Atlantic (Site 415). We interpret the boudinage and deformations of laminae as compaction features in a nonhomogeneous medium.

An unusual kind of cross lamination is frequent at Site 535, particularly in the Neocomian and Albian finegrained deposits. The cross laminations are similar to structures described in Mediterranean Pliocene deposits, which were interpreted to have been caused by currentactions (Site 124, Ryan, Hsü, et al., 1973), and to those observed in the Quaternary of Gulf of California (Soutar et al., 1982). Much discussion during Leg 77 did not lead to an agreement about their significance. The advocates of the current-deposition theory emphasized the presence of cut-and-fill structures, called "pseudoripples" by the others. Again, we prefer a diagenetic origin for these structures. Indeed, they do not show any trace of erosion from Cores 34 to 36 at Site 535 (Fig. 10): when they do (Cores 52 to 75 ), they are accompanied by compaction features (Fig. 44), plastic deformations, and creep-structures. Besides, no sorting or winnowing indicating a current-action were observed in pseudorippled sediments.

In summary, we interpret the alternating laminae of Lower Cretaceous sequences at Sites 535 and 540 as varvelike structures resulting mainly from a vertical supply of biocalcareous and terrigenous particles. Although it seems difficult to separate easily deposits by decantation from low-density distal turbidites (Stanley and Maldonado, 1981). On the other hand, deep currents (although probably weak in Tethyan Ocean) could have contributed to the deposition of laminated sediments (Honjo et al., 1982). However, winnowing and reworking generally did not operate beyond the scale of a given lamina, thus preserving the original microcyclicity of deposition.

Possible effects of differential dissolution. The sea bottom was always significantly above the CCD in Vocontian Basin and at Sites 535 and 540, where even tests of originally aragonitic ammonites were found in the cores. There is no evidence for more intensive dissolution of calcareous organic structures during deposition 
of marls and black shales as opposed to the limestone member of the cycles. Indeed, dissolution marks are very rare on calcareous organic remains and the absolute frequencies of calcareous benthic foraminifers are nearly the same in limestones and marls. In fact, Darmedru (1982) found the most ornated Lenticulina (i.e., best-preserved shells) in marls, not in the limestones, of Vocontian cycles. Thus, we find no evidence that bottom waters were more corrosive during the anoxic period, as postulated by Berger (1970) and others. Finally, we think that dissolution of calcareous remains in seawater was never important and can probably be ignored. This would certainly be the case in the modern ocean above $3000 \mathrm{~m}$ average depth (Denis-Clocchiatti, 1982).

Diagenetic dissolution below the seafloor is another possible cause of marl-limestone differentiation. According to Douglas (1973), planktonic foraminifers are particularly affected by dissolution during diagenesis; moreover, the planktonic/benthic ratio may be severely modified by the differential preservation of benthic and planktonic forms (Coplen and Schlanger, 1973). However, in the sequences studied here we found no trace of dissolution, even in marls where this phenomenon may be first suspected. In fact, diagenetic dissolution is far from ineluctable in marls as shown by de Graciansky and Chenet (1979), who pointed out well-preserved aragonitic shells in black shale-like deposits with low overall carbonate content.

Darmedru and others (1982) discussed the dissolution of radiolarians in Vocontian deposits; they prove the paleoecologic meaning of the distribution of their calcitized fillings in cycles, then the absence of significant differential dissolution in marls and limestones. These results may be applied to DSDP sites.

Concerning nannoplankton distribution, results are more ambiguous. Greater proportions of nannoconids in limestones and of coccoliths in marls have been observed previously, and our observations by scanning electron microscopy confirm this distinction. A factor of preservation may be invoked at first: sensitivity of the two compounds to dissolution would differ in beds and interbeds. (See Montadert, Roberts, et al., 1979; Müller, 1979; Dean et al., 1981; Arthur, 1979). We do not rule out selective dissolution of nannofossils within clayey deposits; it is puzzling, however, that, at Site 535 the few examples of slight corrosion affecting coccoliths are situated in marls as well as in limestones.

In summary, we think that nannofloral abundances were controlled by paleoecology much as the radiolarians were. The hypothesis of periodic carbonate dissolution (Broecker, 1971; Berger, 1973; Thunell, 1976; Dean et al., 1978; Arthur, 1979; Maldonado, 1979; Mélières, 1979; Volat et al., 1980) cannot be applied to the limestone-marl alternations we have studied. More likely, the changes in faunal or floral assemblages that follow the variations in $\mathrm{CaCO}_{3}$ content reflect changes in productivity of surface waters with time.

Cycles and variation of stable isotope ratios. Isotopic ratios of $\mathrm{C}$ and $\mathrm{O}$ measured on bulk samples in this study (as well as in others: Weissert et al., 1979; Cotillon et al., 1980; Moore et al., 1982; de Boer, 1982) gen- erally show a significant distinction between beds and interbeds. How much, if any, of this difference reflects variations in the surface water? How much is caused by differential diagenesis between limestones and marls? Differences in $\mathrm{CaCO}_{3}$ contents and in $\delta^{18} \mathrm{O}$ and $\delta^{13} \mathrm{C}$ within 50 marl/limestone couplets from Sites 535 and 540 are not correlated (Fig. 45). This argues against diagenesis contributing significantly to the distribution of heavy isotopes in the cycles. On the other hand, diagenesis may be responsible for the overall decrease of $\delta^{18} \mathrm{O}$ with burial (Lawrence, 1973; McKenzie et al., 1978). A complete evaluation of these factors is beyond the scope of this paper. We will present it elsewhere. We would like to summarize, however, by expressing our conviction that the variations of ${ }^{13} \mathrm{C}$ and ${ }^{18} \mathrm{O}$ contents in the bulk calcareous fraction (composed mainly of nannofossils) of bed-interbed cycles reflect the same variations in surface water (Létolle et al., 1979).

From this point of view, the differences, noted before, between on-shore sites (in Vocontian Basin, Lombardian Alps, Umbria) and DSDP sites concerning the statistical distribution of $\mathrm{C}$ and $\mathrm{O}$ isotopes in the cycles may be caused by differences in location within Tethyan realm (marginal for the first two, more oceanic for the others). At DSDP sites, the correlation between ${ }^{13} \mathrm{C}$ contents and the sedimentation rate (Fig. 20) indicates that planktonic productivity, to which these values are linked (Weissert et al., 1979; Létolle, 1979; Brosse, 1982) was the most important factor controlling sedimentation rate.

\section{Evidence for Terrestrial and Oceanic Control of the Cycles}

We conclude from the discussion above that overregional rather than local depositional or diagenetic processes controlled the cycles. We will attempt to demonstrate that two kinds of control prevailed, more or less distinctly according to localities: a continental control, through exported terrigenous materials, and an oceanic control acting on the environment.

Oceanic controls. All biological communities, including those involved in sediment genesis, show cyclic variations parallel with lithologic cyclicity. Limestone-marl alternation is then connected to cyclic variations of the marine environment. At the three sites, periods of calcareous deposition are those of intense planktonic sedimentation, the most important part of which is nannoconids. Spherical radiolarians are common, large, but poorly diversified (Darmedru, 1982). Their abundance testifies to a high water fertility (Lisitzin, 1971; Vincent, 1974; Leclaire, 1974). Coccoliths are relatively rare. Periods of marly calcareous deposits represent a maximum of biological diversity and correspond to most favorable times for planktonic foraminifers [Cenomanian(?) of Site 535, Albian of Site 540] and for conical radiolarians (Valanginian of the Vocontian Trough; Darmedru et al., 1982). Coccoliths and nannoconids are observed in the same proportions. During periods of marly deposits, planktonic nannoflora were represented especially by coccolithophorids (i.e., organisms multiplying during periods of low water-productivity) (Olausson, 1981). In the Vocontian Basin, these periods were also connected with 
ลั

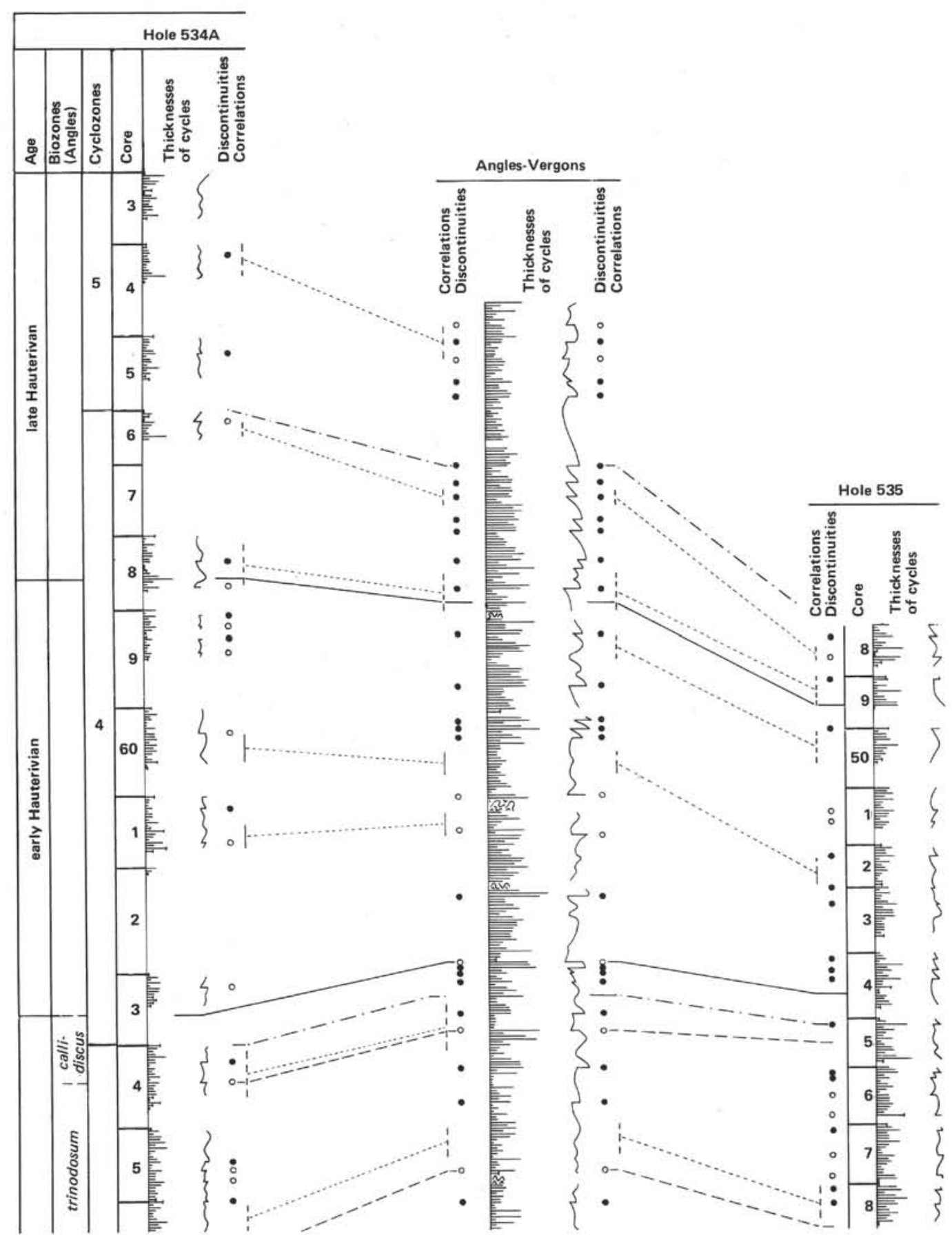




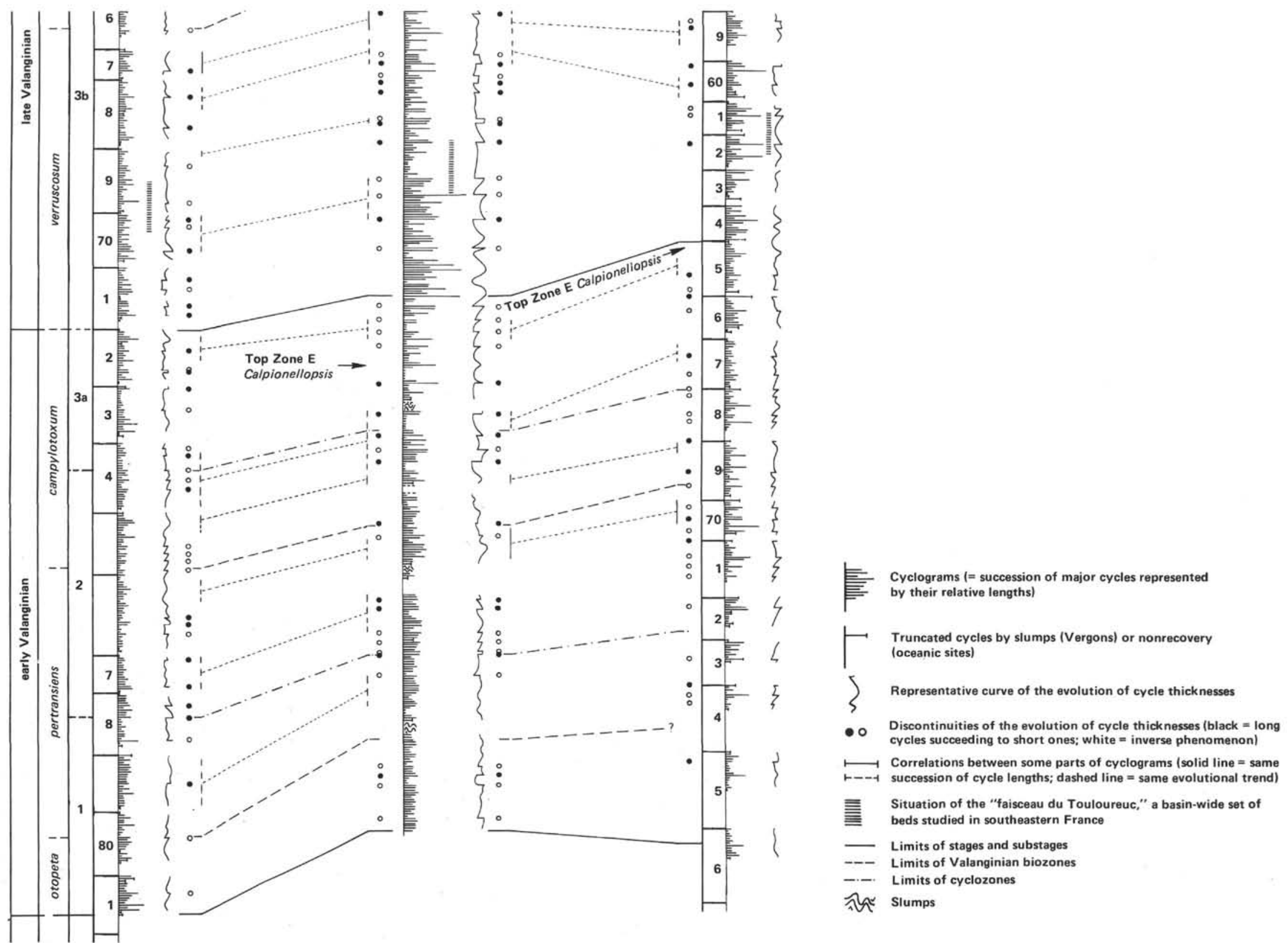

Figure 32. Correlations between Sites 534, 535, and Angles-Vergons based on the cyclicity of deposits illustrated by cyclograms (for Valanginian and Hauterivian periods only). 

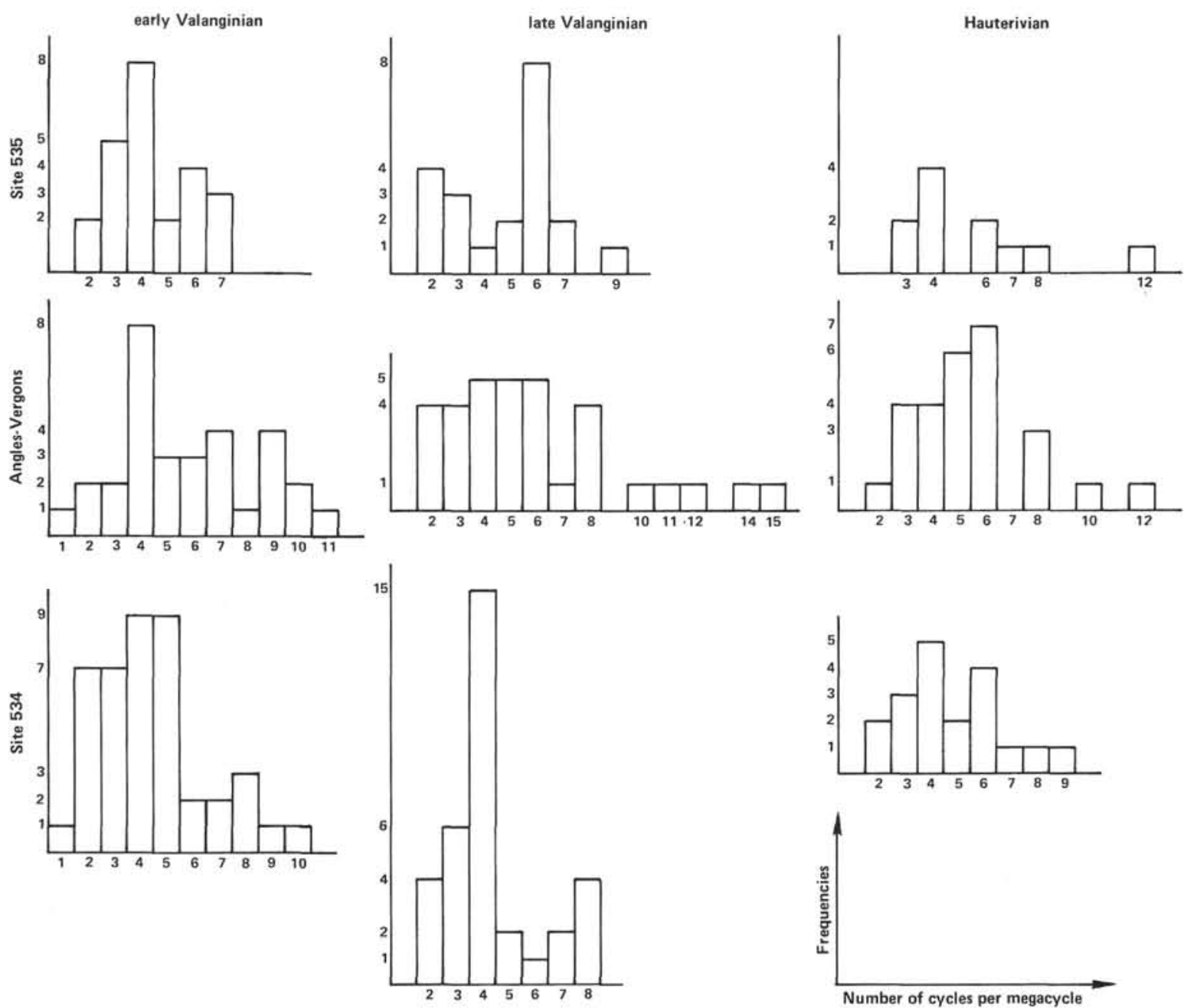

Figure 33. Frequency histograms showing the number of cycles per megacycle for the variations in major bed-interbed cyclicity plotted on Figure 32.

low relative densities, sizes, and diversities for organic communities, both planktonic and benthic (Darmedru, 1982); they corresponded thus to the most unfavorable environments. In summary, we have observed a succession of plankton communities during a limestone-marl cycle. Consequently, the pattern of a passive and continuous calcareous deposition, reduced from time to time by terrigenous inputs or by dissolution (Arthur, 1979; Dean et al., 1981) can be ruled out. On the other hand, biocalcareous influx governed by cyclic environmental modifications is demonstrated, a possibility assumed in previous studies (Thompson, 1977; McCave, 1979; de Boer, 1982).

We assume a control of surface-water productivity, in phase in the entire Tethys (as demonstrated by cyclogram correlations), through cyclic variations of factors such as temperature (Ryan, Hsü, et al., 1973; Worsley, 1973); salinity (Ross and Degens, 1974; Kidd and Ryan, 1978; Thompson, 1977); nutrients; and oxygenation.

These fluctuations affected not only the oceanic photic layer but also bottom waters, as indicated by variations of oxygen content. We observed (like many others before) that limestone beds are more intensively burrowed than marly interbeds. Bioturbation is missing below $0.5 \mathrm{ml} \mathrm{O}_{2}$ /liter $\mathrm{H}_{2} \mathrm{O}$ (Calvert, 1964); thus alternation of burrowed and nonburrowed layers can be interpreted as resulting from cycles of deep-water oxygenation. Higher amounts of pyrite and organic carbon in marls (Fig. 22) (see also Lancelot et al., 1972; Thierstein, 1979; Arthur, 1979; Mélières et al., 1981; Brumsack and Lew, 1982), as well as the low hydrogen index in limestones (Fig. 23) (see also Herbin et al., this vol.), confirm the same trend. For a discussion of models of intermittent anoxia in the deep waters, see Thierstein and Berger, 1978; Weissert and others, 1979; Arthur, 1979; and McCave, 1979.

Briefly, the marl-limestone cycle represents a sequence of two main successive periods. One, corresponding to limestone, is marked by ventilated and nutrient-rich water-body favoring the growth of planktonic life. The other is marked by more stagnant and stratified waters, oxygen depleted near the bottom, nutrient poor in surface waters.

Controls by land masses. Various terrigenous materials, clay minerals particularly, as well as chemical elements of detrital significance generally herald continental events in marine deposits (Chamley, 1979; Einsele, 1982). Assuming that all clay minerals represented in al- 
A

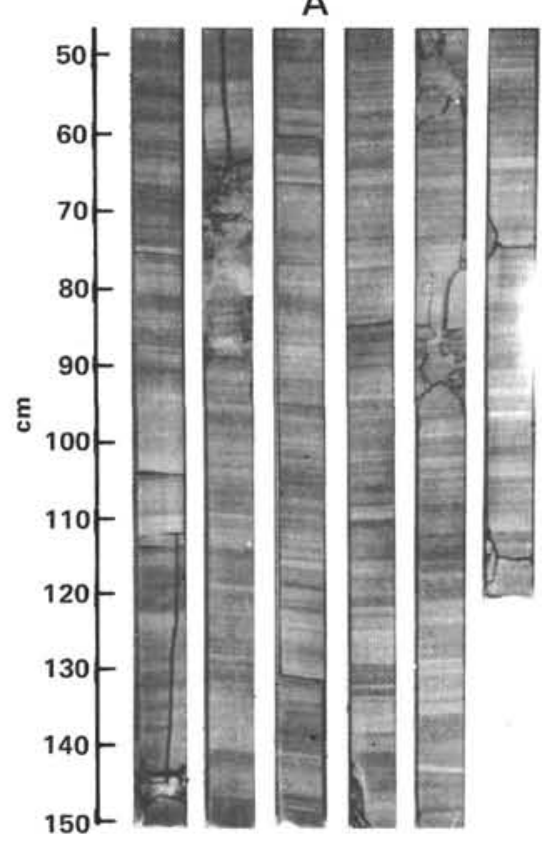

B

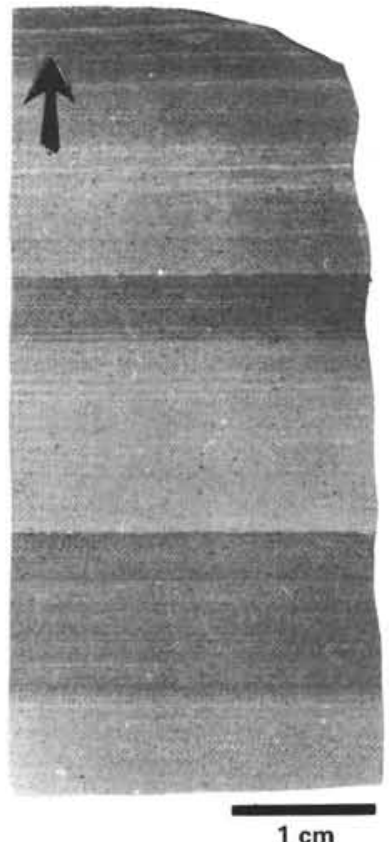

Figure 34. Bandlike alternation of Cenomanian(?) deposits at Site 535. A. Overview of banding in Core 20. B. Close-up view of banding with homogeneous units (Sample 535-21-2, 14-21 cm). Thin white skeletal laminae are superimposed upon it.

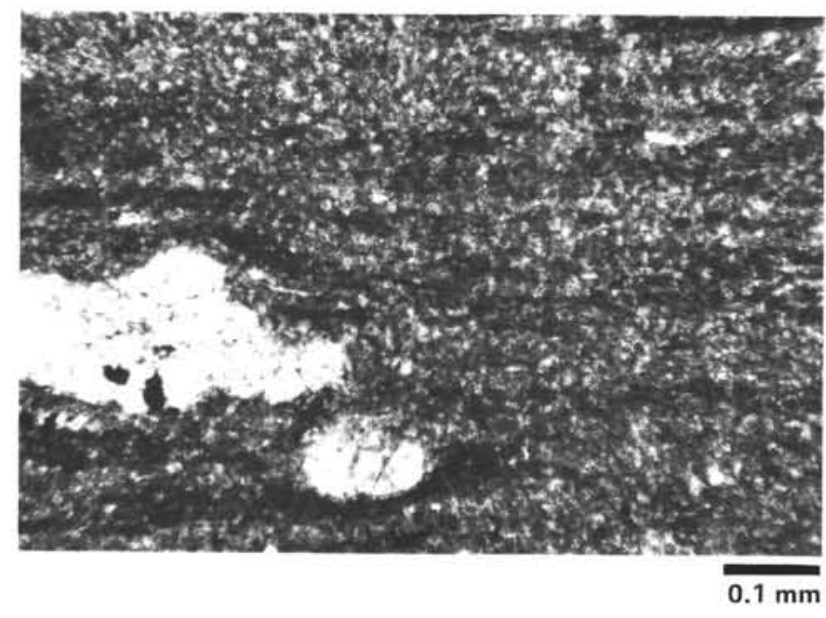

Figure 35. First-order laminae in a marly limestone examined in thin section. Each microcycle consists of a clear lamina and a dark one richer in clay, organic matter, and iron oxide. Evidence of compaction is shown by the deformation of laminae around calcitized debris [Cenomanian(?), Sample 535-42-3, 74-78 cm].

ternating layers of Vocontian Lower Cretaceous are terrigenous, we deduced a cyclicity of continental inputs. According to this concept, marls relatively enriched in kaolinite, illite, quartz, feldspars, and micas represent periods of enhanced continental erosion, compared to limestones, in which smectites are more abundant. The lack of such a clay mineral distribution in cycles at DSDP sites suggests more distant continental sources.

Organic matter is another continental product, particularly when it contains vitrinite and inert material, characterized by a high oxygen index. In the cycles that we have studied, oxygenated organic matter is found in limestones. That location could indicate enhanced continental influence during deposition of calcareous muds; however, this interpretation has been questioned by Kendrick (1979). According to Herbin and others (this vol.), the analyzed organic matter at Site 535 is largely marine in origin. Terrestrial products are not easily proven because the samples located in the vicinity of the path of kerogen type III (Fig. 23) are limestones very poor in organic carbon. However, two calcareous laminated samples (535-69-1, $120 \mathrm{~cm}$ and 535-75-3, $79 \mathrm{~cm}$, Valanginian), which shows a poorly oxygenated environment, contain oxygen-rich organic matter. We conclude that some quantity of terrestrial organic matter may be present in calcareous beds. In the Vocontian Basin, Darmedru (1982) noticed that wood debris is more abundant in limestones than in marls of Valanginian age. Besides, no oxygen index higher than 150 has been recorded in limestones of the Hauterivian at Site 535, which may be correlated with a decrease of burrowing from the Valanginian to the Hauterivian (see Sedimentologic Analysis section), indicating a change toward either a less-oxygenated whole environment or to a less consumable (and/ or less abundant) organic matter. In summary, continents may significantly influence cyclic sedimentation on a bed scale through variations in the flux of clay, organic matter, and dissolved calcium to the ocean.

A final question in the general topic of terrestrial and oceanic controls concerns whether the variation of calcareous and terrigenous fluxes assumed for the alternation of beds and interbeds is also applicable to lamina- 

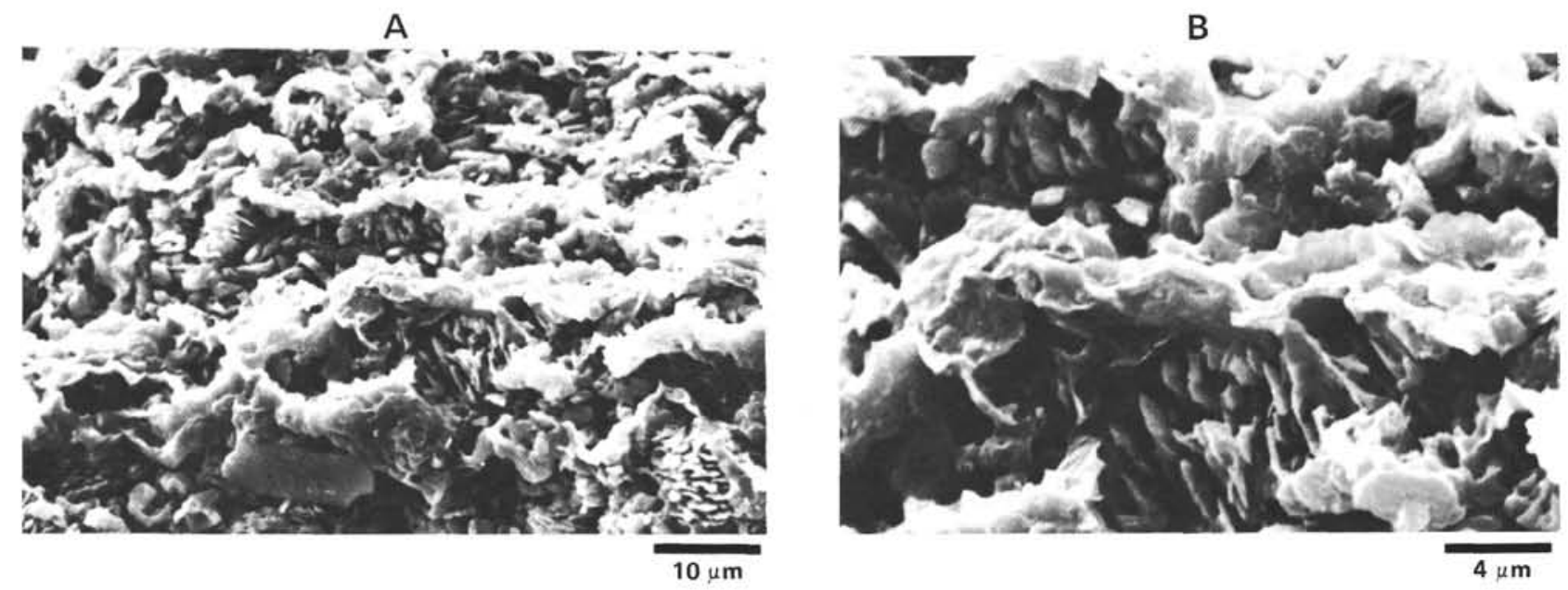

Figure 36. A. First-order lamination examined by scanning electron microscopy, in a marly limestone $\left(74 \% \mathrm{CaCO}_{3}\right)$. Nannoconid-bearing layers alternate with argillaceous ones (upper Valanginian, Sample 535-59-2, 74-79 cm). B. Same sample, close-up view.

A
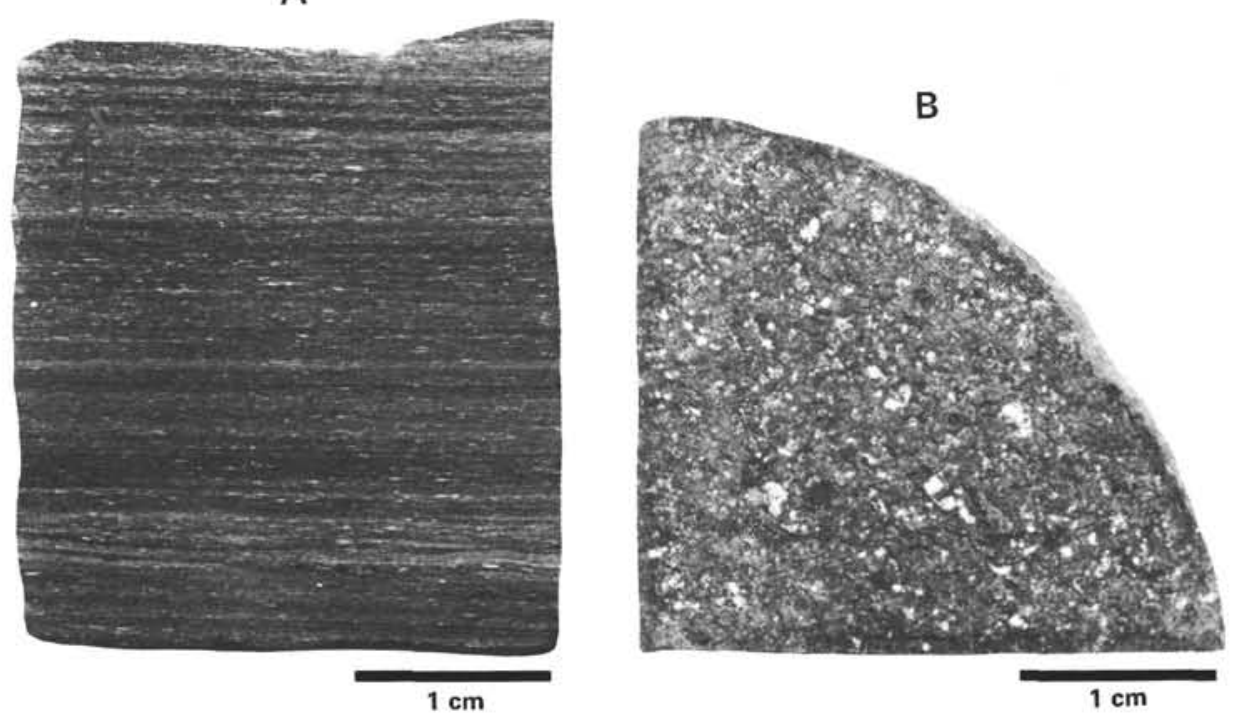

Figure 37. Alignments of calcareous white specks in a laminated marly limestone, corresponding to crushed coprolith-bearing nannofossils (lower Hauterivian, Sample 535-53-4, 41-44 cm). A. Polished section. Specks are gathered in second-order and third-order laminae. B. Viewed on bedding plane.

tion. It seems hazardous to transpose directly this double control to the lamina-scale alternations. As noted above, some very marly sediments appear as white alignments of nannofossils coproliths in a matrix of mixed clay and scattered nannofossils. In this case, periodic inputs of lime, although weak and never able to build continuous calcareous layers, seem evident. The flux of clay minerals would constitute, possibly, a constant background. With alternating successions, in nearly the same proportions, of clayey and nannofossil-rich laminae, two hypotheses may be proposed. (1) Two fluxes alternate, one of them corresponding to periodic planktonic blooms. Donegan and Schrader (1982) use this explanation for the alternation of dark, terrigenous laminae and light diatomaceous laminae in Recent hemipelagic sediments of the central Gulf of California. Dark deposits are related to wet and warm seasons, the others to dry periods promoting upwelling currents. (2) Either the terrigenous or calcareous flux occurs intermittently. In relation to these processes, several sorts of controls have been assumed by authors for the laminated sections of various ages. Concerning the series studied here, more detailed investigations would be required before this problem can be resolved, but the examples we have investigated show that the distribution of nannofossils and planktonic microfossils (foraminifers, radiolarians) in second-order or third-order laminae depends on the same $\mathrm{CaCO}_{3}$ correlation rule as in bed-scale alternations. Thus, all these cycles, whatever their thickness, are probably connected to a common cause. 


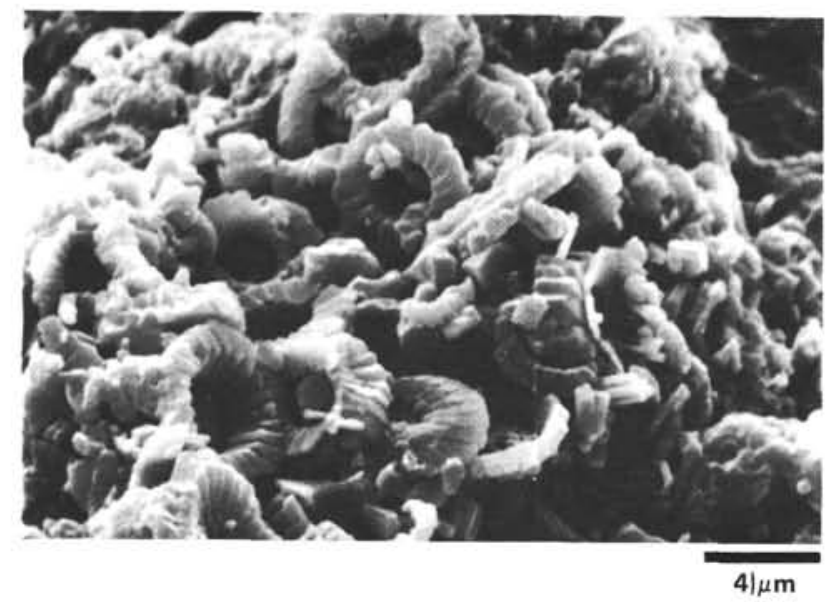

Figure 38. Coprolith crowded with coccoliths, examined by scanning electron microscopy, in a laminated marl (upper Valanginian, Sample $535-57-4,39-44 \mathrm{~cm}$ ).

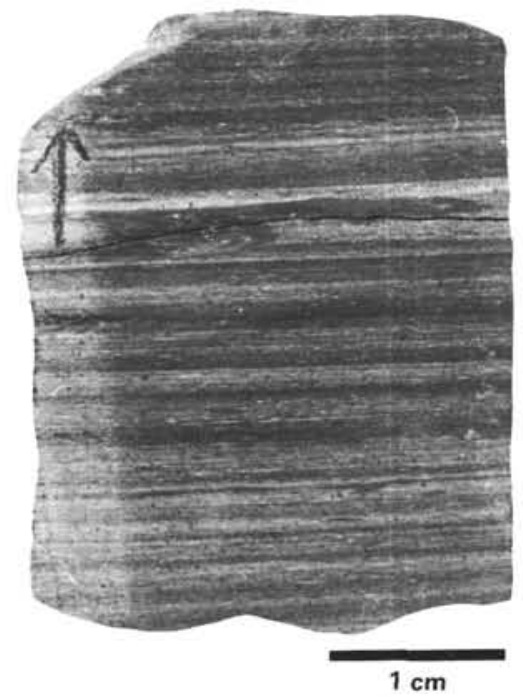

Figure 39. Second-order and third-order laminae in a marly limestone. Each of the laminae forms an alternation between light-colored units (most calcareous) and dark ones (richest in clay and organic matter). Sets of third-order laminae develop a banding (see a light band in the lower part of the section) (lower Valanginian, Sample $535-67-4,122-128 \mathrm{~cm}$ ).

\section{The Orbital Parameter-A Possible Cause of Limestone-Marl Alternation}

The terrestrial and oceanic controls of alternating sedimentation, the very large areas for which bed-for-bed correlations apply, and the periods of bed-scale limestone-marl cycles $(4000-26,000$ yr.) lead us to seek the basic cause of limestone/marl alternations among long climatic cycles. This approach has been already used (Fischer, 1980; Dean et al., 1981; de Boer, 1982). It is based on the hypothesis of cyclic variations of terrestrial solar heat connected to fluctuations of the orbital parameters of the Earth (Milankovitch, 1930), as well as to sun-spot cycles. For orbital cycles, periods would be 21,000 yr. (equinox precession); 40,000 yr. (obliquity of rotational axis), and 97,000 yr. (orbital eccentricity).
Known frequencies of solar cycles are shorter: 11, 22, 556 , and $1668 \mathrm{yr}$.

There is a fairly good correspondence between the orbital variations and Quaternary climatic pulsations (Fairbridge, 1970; Emiliani and Shackleton, 1974; Mornex, 1974; Hays et al., 1976; Ruddiman, 1971; Imbrie and Imbrie, 1980), as well as the global variation of $\mathrm{CaCO}_{3}$ content in Pleistocene cores (Arrhenius, 1952; Hays et al., 1969; Pisias, 1976; Briskin and Harrel, 1980; Moore et al., 1982) and pre-Pleistocene ones (Kerr, 1981). Moreover, the Quaternary calcareous cycles are widespread (Kellogg, 1976; Ruddiman and McIntyre, 1976; Prell and Hays, 1976; Maldonado, 1979).

The link between orbital cycles, climate, and sedimentary cycles is also suggested by Dean and others (1981) for Tertiary deposits (Eocene to Miocene) at Site 366 (Sierra Leone Rise, off western Africa) and by Schwarzacher and Fischer (1982) for the Cretaceous. We basically agree with these authors. Considering the steadiness of astronomic data in a closed system like our solar system, we think that the orbital perturbations may have had similar effects and periods in the Early Cretaceous as in the Tertiary and Quaternary. Further studies will be necessary to compare curves of terrestrial isolation and variations of calcareous flux through studied alternating series, assuming these variations are the best expression of those of the heat flux intensity.

However, a direct comparison between the Early Cretaceous and the Neogene-Quaternary causes many difficulties. The positions of land masses and the pattern of global oceanic circulation were completely different. The Pacific and Tethyan oceans spanned the entire globe (Smith and Briden, 1977) (Fig. 46) and were characterized by circumequatorial currents (McSotay, 1980). Besides, during the Quaternary, polar ice caps enhanced and altered the effect of orbital climatic cycles (Moore et al., 1982; Kerr, 1981). The Cretaceous was probably largely ice free.

Eustatic fluctuations can also induce climatic and lithologic variations. Regressions, by an increase of climate continentality, cause a reduction of mean temperatures and precipitation, as well as an increase of carbonate dissolution (Berger and Vincent, 1981) and a higher supply of terrigenous material. Conversely, transgressions would favor calcareous sedimentation and water oxygenation (Arthur, 1979) whereby the smectite sedimentation is enhanced (Chamley, 1981). The association of limestones and smectite is observed in the Vocontian $\mathrm{Ba}$ sin (see Controls by Land Masses section). Thus, cyclic transgressions and regressions could theoretically induce bed-scale carbonate cycles in the pelagic realm. This kind of control was invoked by Maldonado and Stanley (1976) and Maldonado (1979) to explain the occurrence of deep sapropelic deposits in eastern Mediterranean.

The basic cause of laminated, varvelike cycles we examined in pelagic deposits is not known. The shortest of them, which seem to be annual (see Lamination section), may be related to seasonal cycles like those described in the Quaternary of the Gulf of California (Donegan and Schrader, 1982). The other cycles are nearly 3 and 13 yr. long; climatic or astronomic cycles 
A

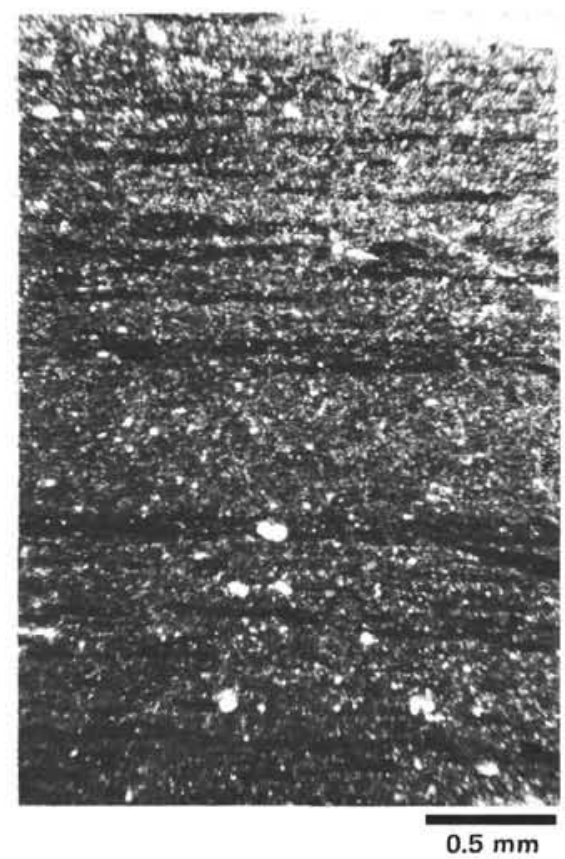

B

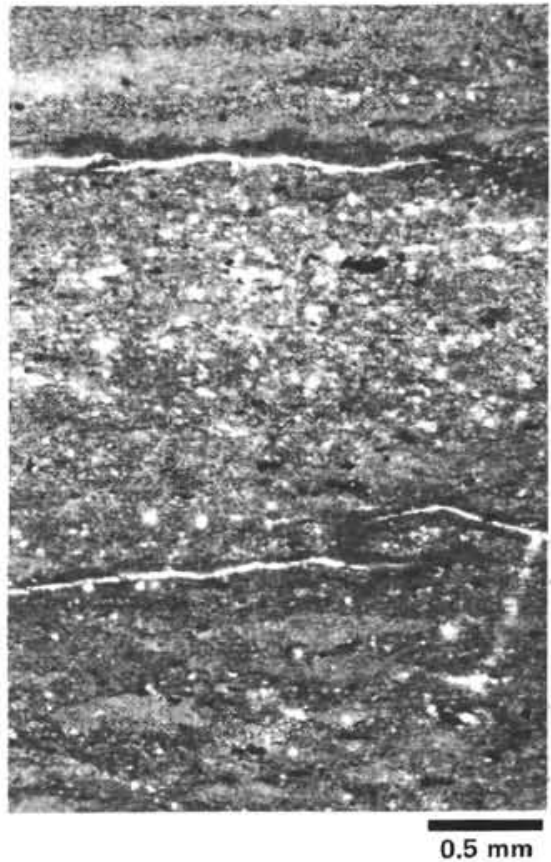

\section{C}

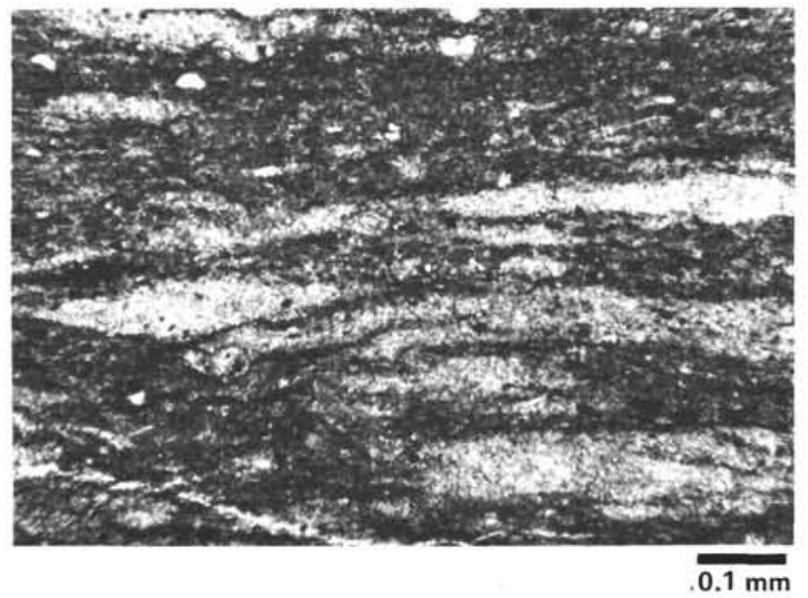

Figure 40. Second-order and third-order laminae examined in thin sections. A. In a marly limestone $\left(73 \% \mathrm{CaCO}_{3}\right)$; second-order alternation between light calcareous layers and dark ones, thinner, richer in clay and organic matter, deformed by compaction; third-order alternation between calcareous set of laminae (in the center where second-order laminae are indistinct because joined) and clayey calcareous ones (on both sides) (Sample 535-42-3, 64-78 cm). B. In a marly limestone $\left(67 \% \mathrm{CaCO}_{3}\right)$; up and down, large second-order calcareous laminae, deformed and disrupted by compaction, compose two third-order laminae calcareous on the whole. In the middle of this section, a third-order lamina, marly on the whole, groups thin second-order laminae (Hauterivian, Sample 535-51-4, 94-99 cm). C. In an argillaceous limestone $\left(83 \% \mathrm{CaCO}_{3}\right)$; enlarged portion of calcareous third-order lamination, showing second-order units, separated by a thin dark clayey film, and deformed as well as disrupted by compaction [Cenomanian(?), Sample 535-35-4, 82-88 cm].

of such periods are unknown today. We think the climatic hypothesis, because it involves a large range of cycle durations, best explains the superimposition of various scales of alternations found in DSDP sites.

\section{CONCLUSIONS}

The comparative study of Lower Cretaceous series in Vocontian Basin (France) and at Sites 534 and $540 \mathrm{em}-$ phasizes the following points about lithology and cyclicity:

1. A similar cyclicity of deposits characterizes the three sequences, whose lithologic expression is a bedscale limestone-marl alternation, with estimated periods of 12,000-26,000 yr. (major cycles), or 4000-11,000 yr. (minor cycles). In addition, the DSDP sites display a millimetric to inframillimetric alternation of laminae in 


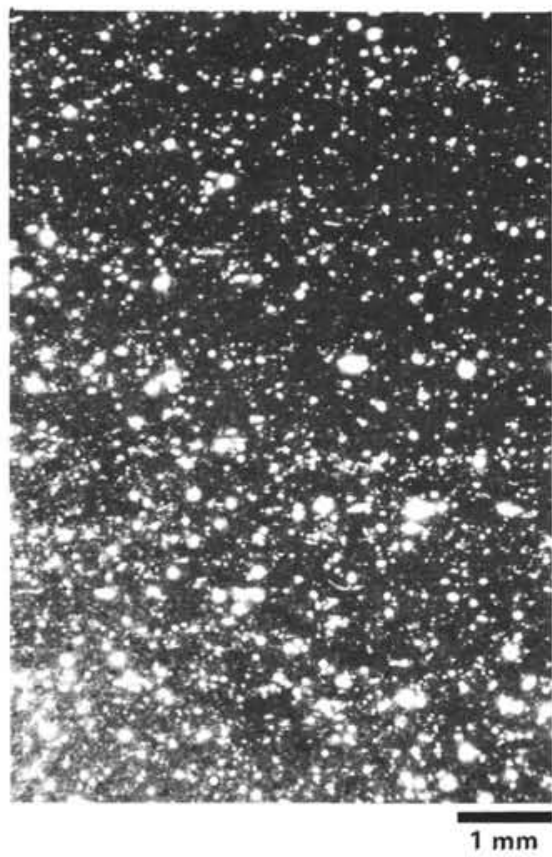

Figure 41. Second-order lamination in radiolarian-rich limestone $(93 \%$ $\mathrm{CaCO}_{3}$ ). Alternation between layers with numerous, large, spherical radiolarians and layers with small, scattered ones (upper Valanginian, Sample 535-64-7, 11-17 cm).

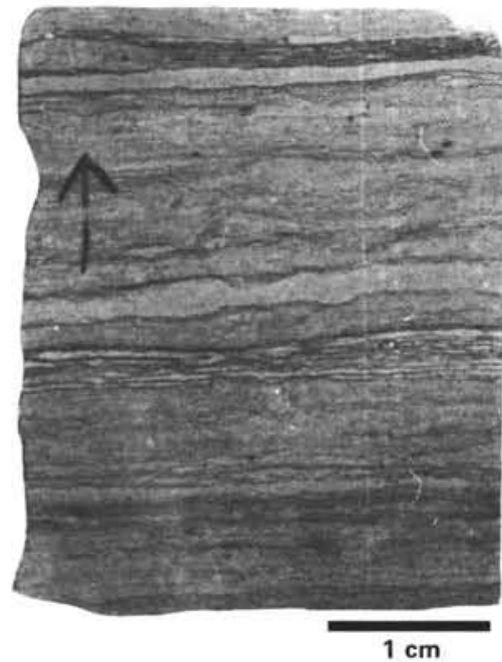

Figure 42. Effect of compaction and pressure-solution on a laminated limestone. The laminae are deformed and constricted or disrupted into lens-shaped amygdaloid units (see also Fig. 40B) (Albian, Sample 535-32-1, 93-98 cm).

marly or marly calcareous facies with estimated periods of 1,3 , and 13 yr. Although characterized by the same basic pattern (an Eocretaceous megacycle), each sequence shows some peculiarities, testifying to the occurrence of local controls on the sedimentation. In spite of resulting lithologic differences found in the series, correlations among the sites in France, the Atlantic, and the Gulf of Mexico are possible on the basis of bed-interbed cyclicity. This correlation supports the theory of global control of the sedimentary rhythms. We believe this control acted through continental masses (argillaceous inputs) and oceanic environments (biocalcareous inputs depending upon planktonic productivity). Ultimately, we assume a climatic control of the cycles tied to the variations of the orbital parameters of the Earth. We also assume that short annual or multi-annual cycles could be responsible for the lamina-scale alternation.

2. An alternation of two climatically contrasted periods may account for the bed-interbed cyclicity. The one would be wet, allowing the development of soils and vegetation on land masses while inducing an enrichment of terrestrial inputs with dissolved substances and organic matter. Ventilated, mixed, and nutrient-rich marine waters favor a calcareous sedimentation through an intense planktonic activity. The other period would be dry; terrestrial inputs are reduced and mainly composed of suspended materials. Oceanic water bodies are motionless and stratified, and bottom environments are poorly ventilated, improving the preservation of organic matter. A low surface-water fertility results in a deposition of marls.

3. Carbonate dissolution does not adequately explain the limestone-marl sequences forming Cretaceous deposits of the Tethys. A good argument, among others, is supplied by fine correlations established between basins of different depth, geometry, and detrital input on the basis of limestone-marl cyclicity.

4. Turbidites rarely obliterate the pelagic limestonemarl rhythm. In spite of high amounts of redeposited material, Hauterivian deposits of Site 534 could be correlated in detail with coeval sediments of Site 535 because of limestone-marl alternations. In basic analysis studies, deposition by gravity processes may generally be overestimated compared to deposition by "climatic alternations."

\section{ACKNOWLEDGMENTS}

The technical support was given at Lyon I University by P. Castelli, T. Chevallier, M. Comtet, G. Marrien, C. Pachiaudi, with financial help from the Centre National de la Recherche Scientifique (France) through Contract No. 8093 of the Géologie et Géophysique des Océans, Action Thématique Programmée. Organic matter analysis was done by G. Deroo and J. P. Herbin at the Institut Français du Pétrole. We thank many scientists for useful discussions, especially $\mathrm{H}$. Chamley, C. Darmedru, E. Davaud, G. Deroo, S. Ferry, C. Gaillard, P. C. de Graciansky, R. Halley, J. P. Herbin, S. Jardiné, E. Jautée, Y. Lancelot, M. Moullade, L. Montadert, K. Pisciotto, I. Premoli Silva, W. Schlager, and R. Tyson.

\section{REFERENCES}

Arrhenius, G., 1952. Sediment cores from the east Pacific. Rept. Swed. Deep-Sea Exped. (1947-1948), 5:1-228.

Arthur, M. A., 1979. North Atlantic Cretaceous black shales: the record at Site 398 and a brief comparison with other occurrences. In Sibuet, J. C., Ryan, W. B. F., et al., Init. Repts. DSDP, 47, Pt. 2: Washington (U.S. Govt. Printing Office), 719-751.

Barker, P., Dalziel, W. D., et al., 1977. Init. Repts. DSDP, 36: Washington (U.S. Govt. Printing Office).

Beaudoin, B., 1977. Méthodes d'analyse sédimentaire et reconstitution du bassin: le Jurassique terminal-Berriasien des chaines subalpines méridionales [Thèse d'Etat]. Université de Caen, Caen.

Berger, W. H., 1970. Planktonic foraminifera selective solution and lysocline. Mar. Geol., 8:111-138.

1973. Deep-sea carbonates: Pleistocene dissolution cycles. J. Foraminiferal Res., 3(4):187-195.

Berger, W. H., and Vincent, E., 1981. Chemostratigraphy and biostratigraphic correlation: exercises in systematic stratigraphy. Oceanol. Acta, Proc. 26th Int. Geol. Cong., Geol. Oceans Symp., Suppl. to Vol. 4:115-127. 
Bolli, H. M., Ryan, W. B. F., et al., 1978. Init. Repts. DSDP, 40: Washington (U.S. Govt. Printing Office).

Briskin, M., and Harrell, J., 1980. Time series analysis of the Pleistocene deep-sea paleoclimatic record. Mar. Geol., 36(1-2):1-22.

Broecker, W. S., 1971. Calcite accumulation rates and glacial to interglacial changes in oceanic mixing. In Turekian, K. K. (Ed.), The Late Cenozoic Glacial Ages: New Haven, Connecticut (Yale Univ. Press), pp. 239-265.

Brosse, E., 1982. Contribution à la minéralogie et à la géochimie des sédiments pélagiques profonds. Comparaison des "Black-Shales" du Crétacé dans l'Atlantique central nord et des dépôts du Malm et du Crétacé en Briançonnais [Thèse Doc. Ing.]. Ecole nationale supérieure des Mines de Paris, Paris.

Bruckner, W. D., 1953. Cyclic calcareous sedimentation as an index of climatic variations in the past. J. Sediment. Petrol., 235-237.

Brumsack, H. J., and Lew, M., 1982. Inorganic geochemistry of Atlantic ocean sediments with special reference to Cretaceous blackshales. In von Rad, U., Hinz, K., Sarnthein, M., and Seibold, E. (Ed.), Geology of the Northwest African Continental Margin: Berlin, Heidelberg, New York (Springer), pp. 661-685.

Busnardo, R., Thieuloy, J. P., and Moullade, M., 1979. Hypostratotype mésogéen de l'étage Valanginien (Sud-Est de la France) (Vol. 6): Paris (Centre National de la Recherche Scientifique).

Calvert, S. E., 1964. Factors affecting distribution of laminated diatomaceous sediments in Gulf of California. Am. Assoc. Pet. Geol. Mem., 3:311-330.

Carozzi, A., 1955. Some remarks on cyclic calcareous sedimentation as an index of climatic variations. J. Sediment. Petrol., 25(1):78-79.

Chamley, H., 1979. North Atlantic clay sedimentation and paleoenvironment since the Late Jurassic. In Talwani, M., Hay, W., and Ryan, W. B. F. (Eds.), Deep Drilling Results in the Atlantic Ocean: Continental Margins and Paleoenvironments: Washington (Am. Geophys. Union) Maurice Ewing Series 3, 342-361.

1981. Long-term trend in clay deposition in the ocean. Oceanol. Acta, Proc. 26th Int. Geol. Congr., Geol. Oceans Symp., Suppl. to Vol. 4:105-110.

Coplen, T. B., and Schlanger, S. G., 1973. Oxygen and carbon isotope studies of carbonate sediments from Site 167, Magellan Rise, Leg 17. In Winterer, E. L., Ewing, J. I., et al., Init. Repts. DSDP, 17: Washington (U.S. Govt. Printing Office), 505-510.

Cotillon, P., 1971. Le Crétacé inférieur de l'arc subalpin de Castellane. Stratigraphie et sédimentologie. Mem. Bur. Rech. Geol. Min. 68.

Cotillon, P., Ferry, S., Gaillard, C., Jautée, E., Latreille, G., and Rio, M., 1979. A la recherche des facteurs oscillants de la sédimentation marine ancienne par l'étude des alternances marno-calcaires. C.R. Acad. Sci. 289(15):1121-1124.

1980. Fluctuation des paramètres du milieu marin dans le domaine vocontien (France S-E) au Crétacé inférieur: mise en évidence par l'étude des formations marno-calcaires alternantes. Bull. Soc. Geol. Fr., 7(XXII,5):735-744.

Cronan, D. S., Damiani, V. V., Kinsman, D. J. J., and Thiede, J., 1974. Sediments from the Gulf of Aden and Western Indian Ocean. In Fisher, L., Bunce, E. T., et al., Init. Repts. DSDP, 24: Washington (U.S. Govt. Printing Office), 1047-1110.

Darmedru, C., 1982. La microfaune dans les alternances marne-calcaire pélagiques du Crétacé inférieur vocontien (Sud-Est de la France). Mise en évidence d'oscillations climatiques [Thèse $3 \mathrm{e}$ cycle]. Université Lyon I, Lyon.

Darmedru, C., Cotillon, P., and Rio, M., 1982. Rhythmes climatiques et biologiques en milieu marin pélagique. Leurs relations dans les dépôts crétacés alternants du bassin vocontien (S-E France). Bull. Soc. Geol. Fr., 7(24,3):627-640.

Davis, J. C., 1973. Statistics and Data Analysis in Geology: New York (Wiley).

Dean, W. E., Gardner, J. V., Jansa, L. F., Čepek, P., and Seibold, E., 1978. Cyclic sedimentation along the continental margin of Northwest Africa, In Lancelot, Y., Seibold, E., et al., Init. Repts. DSDP, 41: Washington (U.S. Govt. Printing Office), 965-989.

Dean, W. E., Gardner, J. V., and Čepek, P., 1981. Tertiary carbonate dissolution cycles on the Sierra Leone Rise, Eastern Equatorial Atlantic Ocean. Mar. Geol., 39:81-101.

de Boer, P. L., 1982. Cyclicity and the storage of organic matter in Middle Cretaceous Pelagic sediments. In Einsele, G., and Seilacher,
A. (Eds.), Cyclic and Event Stratification: Berlin, Heidelberg, New York (Springer Verlag), pp. 456-475.

de Graciansky, P. C., Brosse, E., Deroo, G., Herbin, J. P., Montadert, L., Müller, C., Schaaf, A., and Sigal, J., 1982. Les formations d'âge crétacé de l'Atlantique Nord et leur matière organique: paléogéographie et milieux de dépôt. Rev. Inst. Fr. Pet., 37(3):275-336.

de Graciansky, P. C., and Chenet, P. Y., 1979. Sedimentological study of Cores 138 to 56 (upper Hauterivian to middle Cenomanian), an attempt at reconstruction of paleoenvironments. In Sibuet, J.-C., Ryan, W. B. F., et al., Init. Repts. DSDP, 47, Pt. 2: Washington (U.S. Govt. Printing Office), 403-418.

Denis-Clocchiatti, M., 1982. Sedimentation carbonatée et paléoenvironnement dans l'Océan Indien au Cénozoïque. Mem. Soc. Geol. Fr., N. Ser., 60(143).

Deroo, G., Herbin, J.-P., Roucaché, J., Tissot, B., Albrecht, R., and Schaeffle, J., 1978. Organic geochemistry of some Cretaceous black shales from Site 367, Leg 41, eastern North Atlantic. In Lancelot, Y., Seibold, E., et al., Init. Repts. DSDP, 41: Washington (U.S. Govt. Printing Office), 865-873.

Donegan, D., and Schrader, H., 1982. Biogenic and abiogenic components of laminated hemipelagic sediments in the central Gulf of California. Mar. Geol., 48:215-237.

Donnelly, T. W., Francheteau, J., et al., 1980. Init. Repts. DSDP, 51, 52, 53, Pts. 1 and 2: Washington (U.S. Govt. Printing Office).

Douglas, R. G., 1973. Planktonic foraminiferal biostratigraphy in the Central North Pacific. In Winterer, E. L., Ewing, J. I., et al. Init. Repts. DSDP, 17: Washington (U.S. Govt. Printing Office), 673-694.

Einsele, G., 1982. Limestone-marl cycles (periodites): diagnosis, significance, causes, a review. In Einsele, G., and Seilacher, A. (Eds.) Cyclic and Event Stratification: Berlin, Heidelberg, New York (Springer), pp. 8-53.

Emiliani, C., and Shackleton, N. J., 1974. The Brunhes Epoch; isotopic paleotemperatures and geochronology. Science, 183(4124): 511-514.

Fairbridge, R. W., 1970. World paleoclimatology of the Quaternary. Rev. Geogr. Phys. Geol. Dyn., 2(12,2):97-104.

Ferry, S., 1976. Cône d'épandage bioclastique en eau profonde et glissements sous-marin dans le Barrémien et l'Aptien inférieur vocontiens de la Drôme. Implications paléostructurales [Thèse Doct. $3 e$ cycle]. Université de Lyon I, Lyon.

Ferry, S., and Schaaf, A., 1981. The early Cretaceous environment at Deep Sea Drilling Project Site 463 (mid-Pacific mountains) with reference to the Vocontian Trough (French subalpine ranges). In Thiede, J., Vallier, T. L., et al., Init. Repts. DSDP, 62: Washington (U.S. Govt. Printing Office), 669-682.

Fischer, A. G., 1980. Gilbert-bedding rhythms and geochronology. Geol. Soc. Am., Spec. Paper 183, 93-104.

Freeman, T., and Enos, P., 1978. Petrology of Upper Jurassic-Lower Cretaceous limestones, DSDP Site 391. In Benson, W. E., Sheridan, R. E., et al., Init. Repts. DSDP, 44: Washington (U.S. Govt. Printing Office), 463-475.

Gignoux, M., 1950. Sédimentation rythmique dans les plaines maritimes et au fond des mers. C.R. Acad. Sci., Ser. D, 230(8):693-698.

Hays, J. D., Saito, T., Opdyke, N. D., and Burckle, L. H., 1969. Pliocene-Pleistocene sediments of the equatorial Pacific: their paleomagnetic biostratigraphic and climatic record. Geol. Soc. Am. Bull., 80:1481-1514.

Hays, J. D., Imbrie, J., and Shackleton, N. J., 1976. Variations in the Earth's orbit: pacemaker of the Ice Ages. Science, 194(4270): 1121-1132.

Hollister, C. D., Ewing, J. I., et al., 1972. Init. Repts. DSDP, 11: Washington (U.S. Govt. Printing Office).

Honjo, S., Maganini, S. J., and Poppe, L. J., 1982. Sedimentation of lithogenic particles in the deep oceans. Mar. Geol., 50:199-220.

Imbrie, J., and Imbrie, J. Z., 1980. Modeling the climatic response to orbital variations. Science, 207:943-953.

Jansa, L., Gardner, J. V., and Dean, W. E., 1978. Mesozoic sequences of the central North Atlantic. In Lancelot, Y., Seibold, E., et al., Init. Repts. DSDP, 41: Washington (U.S. Govt. Printing Office), 991-1031.

Jansa, L. F., Enos, P., Tucholke, B. E., Gradstein, F. M., and Sheridan, R. E., 1979. Mesozoic sedimentary formations of the North American Basin, western North Atlantic. In Talwani, M., Hay, W., 
and Ryan, W. B. F. (Eds.), Deep Drilling Results in the Atlantic Ocean: Continental Margins and Paleoenvironment: Washington (Am. Geophys. Union), Maurice Ewing Series 3:1-57.

Jenkyns, H. C., 1976. Sediments and sedimentary history, Manahiki Plateau, South Pacific Ocean. In Schlanger, S. O., Jackson, E. D., et al., Init. Repts. DSDP, 33: Washington (U.S. Govt. Printing Office), 873-890.

Jouchoux, A., 1982. Les alternances pélagiques marne-calcaire du bassin vocontien (S-E France): essai de caractérisation géochimique des bancs et interbancs dans le Valanginien supérieur. 9e réunion Ann. Sci. Terre, Soc. Geol. Fr., p. 330. (Abstract)

Kaufmann, E. G., 1982. Ecology and depositional environments of chalk-marl and limestone-shale rhythms in the Cretaceous of North America. In Einsele, G., and Seilacher, A. (Eds.), Cyclic and Event Stratification: Berlin, Heidelberg, New York (Springer Verlag), p. 97. (Abstract)

Kellogg, T. B., 1976. Late Quaternary climatic changes: evidence from deep-sea cores of Norwegian and Greenland seas. In Cline, R. M., and Hays, J. D. (Eds.), Investigation of Late Quaternary Paleoceanography and Paleoclimatology: Boulder, Colorado (Geol. Soc. Am. Mem.), 145:77-110.

Kendrick, J. W., 1979. Geochemical studies of black clays from Leg 43, DSDP. In Tucholke, B. E., Vogt. P. R., et al., Init. Repts. DSDP, 43: Washington (U.S. Govt. Printing Office), 633-642.

Kennedy, W. J., and Odin, G. S., 1982. The Jurassic and Cretaceous time scale in 1981. In Odin, G. S. (Ed.), Numerical Dating in Stratigraphy, pp. 556-592.

Kerr, R. A., 1981. Milankovitch climate cycles: old and unsteady. Science, 213(4):1095-1096.

Kidd, R. B., Cita, M. B., and Ryan, W. B. F., 1978. Stratigraphy of eastern Mediterranean Sapropel sequences recovered during DSDP Leg $42 \mathrm{~A}$ and their paleoenvironmental significance. In Hsü, K. J., Montadert, L., et al., Init. Repts. DSDP, 42, Pt. 1: Washington (U.S. Govt. Printing Office), 421-443.

Lancelot, Y., Hathaway, J. C., and Hollister, C. D., 1972. Lithology of sediments from the western North Atlantic, Leg XI, DSDP. In Hollister, C. D., Ewing, J. I., et al., Init. Repts. DSDP, 11: Washington (U.S. Govt. Printing Office), 901-950.

Lancelot, Y., Seibold, E., et al., 1978. Init. Repts. DSDP, 41: Washington (U.S. Govt. Printing Office).

Lancelot, Y., Winterer, E. L., et al., 1980. Init. Repts. DSDP, 50: Washington (U.S. Govt. Printing Office).

Lawrence, J. R., 1973. Interstitial water studies, Leg 15, stable oxygen and carbon isotope variations in water, carbonates, and silicates from the Venezuela Basin (Site 149) and the Aves Rise (Site 148). In Heezen, B. C., MacGregor, I. D., et al., Init. Repts. DSDP, 20: Washington (U.S. Govt. Printing Office), 891-900.

Leclaire, L., 1974. Late Cretaceous and Cenozoic pelagic depositspaleoenvironment and paleoceanography of the central Western Indian Ocean. In Simpson, E. S. W., Schlich, R., et al., Init. Repts. DSDP, 25: Washington (U.S. Govt. Printing Office), 481-505.

Le Doeuff, D., 1977. Rythmes et contournements synsédimentaires en série carbonatée alternante. Reconstitution paléomorphologique au Crétacé inférieur dans les chains subalpines méridionales. [Thèse 3e cycle]. Université de Paris, Paris.

Létolle, R., Vergnaud Grazzini, C., and Pierre, C., 1979. Oxygen and carbon isotopes from bulk carbonates and foraminiferal shells at DSDP Sites 400, 401, 402, 403, and 406. In Montadert, L., Roberts, D.G., et al., Init. Repts. DSDP, 48: Washington (U.S. Govt. Printing Office), 741-755.

Létolle, R., 1979. Oxygen 18 and Carbon 13 isotopes from bulk carbonate samples, Leg 47B. In Sibuet, J.-C., Ryan, W. B. F., et al., Init. Repts. DSDP, 47, Pt. 2: Washington (U.S. Govt. Printing Office), 493-496.

Lisitzin, A. P., 1971. Distribution of siliceous microfossils in suspension and in bottom sediments. In Funnell, B. M., and Riedel, W. R., (Eds.), The Micropaleontology of Oceans: New York (Cambridge Univ. Press), pp. 173-195.

Lombard, A., 1956. Géologie sédimentaire: les séries marines: Paris (Masson).

McCave, I. N., 1979. Depositional features of organic-carbon-rich black and green mudstones at DSDP Sites 386 and 387, western
North Atlantic. In Tucholke, B. E., Vogt. P. R., et al., Init. Repts. DSDP, 43: Washington (U.S. Govt. Printing Office), 411-416.

McKenzie, J., Bernouilli, D., and Garrison, R. E., 1978. Lithification of pelagic-hemipelagic sediments at DSDP Site 372: oxygen isotope alternation with diagenesis. In Hsü, J., Montadert, L., et al., Init. Repts. DSDP, 42, Pt. 1: Washington (U.S. Govt. Printing Office), 473-478.

McSotay, O., 1980. Mollusques benthiques du Crétacé inférieur: une méthode de corrélation entre la Téthys mésogéenne et le domaine paléo-caraïbe (Vénézuela) [Thèse d'Université]. Université de Lyon, Lyon.

Maldonado, A., 1979. Upper Cretaceous and Cenozoic depositional processes and facies in the distal North Atlantic continental margin off Portugal, DSDP Site 398. In Sibuet, J.-C., Ryan, W. B. F., et al., Init. Repts. DSDP, 47, Pt. 1: Washington (U.S. Govt. Printing Office), 373-401.

Maldonado, A., and Stanley, D. J., 1976. The Nile Cone: submarine fan development by cyclic sedimentation. Mar. Geol., 20:27-40.

Manivit, H., 1979. Les nannofossiles. In Busnardo, R., Thieuloy, J. P., and Moullade, M. (Eds.), Hypostratotype mésogéen de l'étage Valanginien (S-E de la France) (Vol. 6): Paris (Centre National de la Recherche Scientifique), 87-98.

Mélières, F., 1979. Mineralogy and geochemistry of selected Albian sediments from the Bay of Biscay, Deep Sea Drilling Project Leg 48. In Montadert, L., Roberts, D. G., et al., Init. Repts. DSDP, 48: Washington (U.S. Govt. Printing Office), 855-875.

Mélières, F., Deroo, G., and Herbin, J.-P., 1981. Organic-matterrich and hypersiliceous Aptian sediments from western Mid-Pacific mountains. DSDP Leg 62. In Thiede, J., Vallier, T. L., et al., Init. Repts. DSDP, 62: Washington (U.S. Govt. Printing Office), 903-915.

Milankovitch, M., 1930. Mathematische Klimalehre und Astronomische Theorie der Klimaschwankungen. In Koppen, W., and Geiger, R. (Eds.), Handbuch der Klimatologie (Vol. 1, Pt. A): Berlin (Gebrüder Borntraeger), 176.

Montadert, L., Roberts, D. G., et al., 1979. Init. Repts. DSDP, 48: Washington (U.S. Govt. Printing Office).

Moore, T. C., Pisias, N. G., and Dunn, D. A., 1982. Carbonate time series of the Quaternary and late Miocene sediments in the Pacific Ocean: a spectral comparison. Mar Geol., 46:217-233.

Morner, N. G., 1974. Sea level variations and climatic fluctuations. Les Méthodes Quantitatives d'étude des variations du climat au cours du Pleistocène, Colloque Int. du CNRS (1973), 219:135-141.

Moullade, M. 1966. Etude stratigraphique et micropaléontologique du Crétacé inférieur de la "fosse vocontienne".Doc. Lab. Géol. Fac. Sci. Lyon, 15.

Müller, C., 1979. Calcareous nannofossils from the North Atlantic (Leg 48). In Montadert, L., Roberts, D. G., et al., Init. Repts. DSDP, 48: Washington (U.S. Govt. Printing Office), 589-640.

Noël, D., 1968. Nature et genèse des alternances de marnes et de calcaires du Barrémien supérieur d'Angles (fosse vocontienne, BassesAlpes). C.R. Acad. Sci., Ser. D, 266:1223-1225.

Noël, D., and Manivit, H., 1978. Nannofacies de "black shales" aptiennes et albiennes d'Atlantique sud (Legs 36 et 40 ). Intérêt sédimentologique. Bull. Soc. Geol. Fr., 7(20,4):491-502.

Olausson, E., 1981. Remarks on some Cenozoic core sequences from the Central Pacific with discussion of the role of Coccolithophorids and Foraminifera in carbonate deposition. Medd. Oceanogr. Inst., 29:1-35.

Pardo, G., 1975. Geology of Cuba. In Nairn, A. E. M., and Stehli, F. G. (Eds.), The Gulf of Mexico and the Carribbean, The Ocean Basins and Margins (Vol. 3): New York, (Plenum Press) 553-615.

Pflaumann, U., and Cepek, P., 1982. Cretaceous foraminiferal and nannoplankton biostratigraphy and paleoecology along the West African Continental Margin. In von Rad, U., Hinz, K., Sarnthein, M., and Seibold, E. (Eds.), Geology of the Northwest African Continental Margin: Berlin, Heidelberg, New York (Springer), pp. 333-346.

Pisias, N. G., 1976. Late Quaternary sediments of Panama basin: sedimentation rates, periodicities and controls of carbonate and opal accumulation. In Cline, R. M., and Hays, J. D., (Eds.), Investigation of Late Quaternary Paleoceanography and Paleoclimatology: Boulder, Colorado (Geol. Soc. Am. Mem.), 145:375-388. 
Porthault, B., 1978. Géochimie et environnement sédimentaire. Exemple d'application dans l'étude du Crétacé du bassin rhodanien. Livre Jubilaire Jacques Flandrin. Doc. Lab. Geol. Fac. Sci. Lyon, Hors. S., 4:361-405.

Prell, W. L., and Hays, J. D., 1976. Late Pleistocene faunal and temperature pattern of the Colombia Basin, Caribbean Sea. In Cline, R. M., and Hays, J. D. (Eds.), Investigation of Late Quaternary Paleoceanography and Paleoclimatology: Boulder, Colorado (Geol. Soc. Am. Mem.), 145:201-220.

Ross, D. A., Neprochnov, Y. P., et al., 1978. Init. Repts. DSDP, 42, Pt. 2: Washington (U.S. Govt. Printing Office).

Ross, D. A., and Degens, E. T., 1974. Recent sediments of Black Sea. In Degens, E. T., and Ross, D. A. (Eds.), The Black Sea, Geology, Chemistry and Biology: Tulsa, Oklahoma (Am. Assoc. Pet. Geol. Mem.), 20:183-199.

Ruddiman, W. F., 1971. Pleistocene sedimentation in the equatorial Atlantic: stratigraphy and faunal paleoclimatology. Geol. Soc. Am. Bull., 82(2):283-302.

Ruddiman, W. F., and McIntyre, A., 1976. Northeast Atlantic paleoclimatic changes over the past 600,000 years. In Cline, R. M., and Hayes, J. D. (Eds.), Investigation of Late Quaternary Paleoceanography and Paleoclimatology: Boulder, Colorado (Geol. Soc. Am. Mem.), 145:111-146.

Ryan, W. B. F., Hsü, K. J., et al., 1973. Init. Repts, DSDP, 13, Pt. 1: Washington (U.S. Govt. Printing Office).

Schwarzacher, W., 1964. An application of statistical time series analysis of a limestone-shale sequence. J. Geol., 72:195-213.

Schwarzacher, W., and Fischer, A. G., 1982. Limestone-shale bedding and perturbation of the Earth's orbit. In Einsele, G., and Seilacher, A. (Eds.), Cyclic and Event Stratification: Berlin, Heidelberg, New York (Springer), pp. 72-95.

Sheridan, R. E., Gradstein, F. M., et al., 1983. Init. Repts. DSDP, 76: Washington (U.S. Govt. Printing Office).

Sibuet, J.-C., Ryan, W. B. F., et al., 1979. Init. Repts. DSDP, 47, Pt. 2: Washington (U.S. Govt. Printing Office).

Simpson, E. S. W., Schlich, R., et al., 1974. Init. Repts. DSDP, 25 : Washington (U.S. Govt. Printing Office).

Smith, A. G., and Briden, J. C., 1977. Mesozoic and Cenozoic paleocontinental maps: New York (Cambridge Univ. Press).

Soutar, A., Johnson, S. R., Taylor, E., and Baumgartner, T. R., 1982. $\mathrm{X}$-Radiography of Hole 480 . Procedures and results. In Curray, J. R., Moore, D. G., et al., Init. Repts. DSDP, 64: Washington (U.S. Govt. Printing Office), 1183-1191.
Stanley, D. J., and Maldonado, A., 1981. Depositional models for fine-grained sediment in the western Hellenic Trench, Eastern Mediterranean. Sedimentology, 28(2):273-290.

Thiede, J., Vallier, T. L., et al., 1981. Init. Repts. DSDP, 62: Washington (U.S. Govt. Printing Office).

Thierstein, H. R., 1979. Paleoceanographic implications of organic carbon and carbonate distribution in Mesozoic deep sea sediments. In Talwani, M., Hay, W., Ryan, W. B. F. (Eds.), Deep Sea Drilling Results in the Atlantic Ocean: Continental Margins and Paleoenvironment. Washington (Am. Geophys. Union), Maurice Ewing Series, 3:249-274.

Thierstein, H. R., and Berger, W. H., 1978. Injection events in ocean history, Nature, 276:461-466.

Thompson, R. W., 1977. Mesozoic sedimentation on the eastern Falkland Plateau. In Barker P., Dalziel, I. W. D., et al., Init. Repts. DSDP, 36: Washington (U.S. Govt. Printing Office), 877-891.

Thunell, R. C., 1976. Optimum indices of calcium carbonate dissolution in deep sea sediments. Geology, 4:525-528.

Tucholke, B. E., Vogt, P. R., et al., 1979. Init. Repts. DSDP, 43: Washington (U.S. Govt. Printing Office).

Vincent, E., 1974. Cenozoic planktonic biostratigraphy and paleoceanography of the tropical western Indian Ocean. In Fisher, R. L. Bunce, E. T., et al., Init. Repts. DSDP, 24: Washington (U.S. Govt. Printing Office), 1111-1150.

Volat, J. L., Pastouret, L., and Vergnaud Grazzini, C., 1980. Dissolution and carbonate fluctuations in Pleistocene deep-sea cores: a review. Mar. Geol. 34(1-2):1-28.

Weissert, H., McKenzie, J., and Hochuli, P., 1979. Cyclic anoxic events in the Early Cretaceous Tethys Ocean. Geology, 7:147-151.

Winterer, E. L., Ewing, J. I., et al., 1973. Init. Repts. DSDP, 17: Washington (U.S. Govt. Printing Office).

Worsley, T. R., 1973. Calcareous nannofossils: Leg 19 of the DSDP. In Creager, J. S., Scholl, D. W., et al., Init. Repts. DSDP, 19: Washington (U.S. Govt. Printing Office), 741-750.

Ziegler, B., 1958. Feinstratigraphische Untersuchungen im Oberjura Südwestdeutschlands, ihre Bedeutung für Paläontologie und $\mathrm{Pa}$. läogeographie. Eclogae Geol. Helv., 58:265-278.

Date of Initial Receipt: January 17, 1983 Date of Acceptance: November 30, 1983 

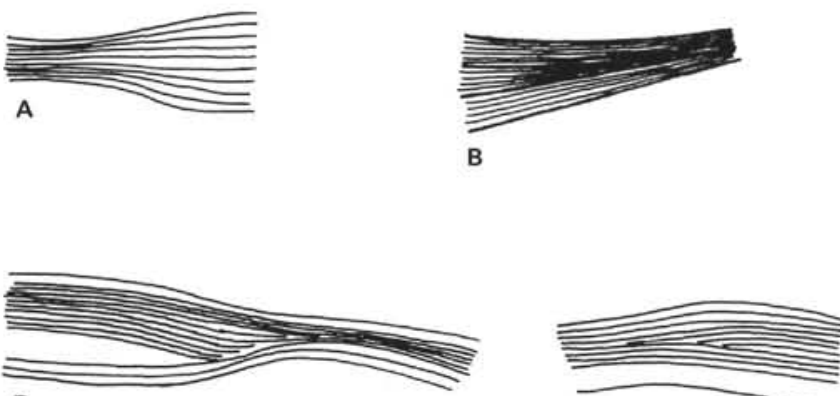

G

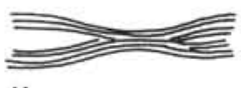

$\mathrm{H}$

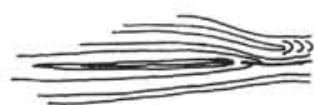

K

J

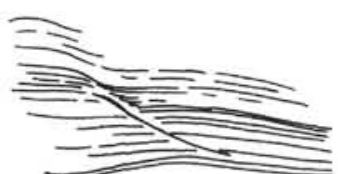

M
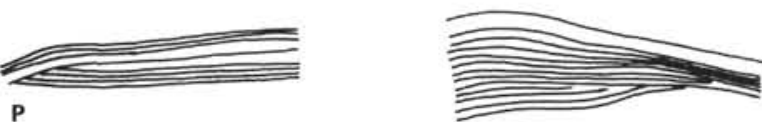
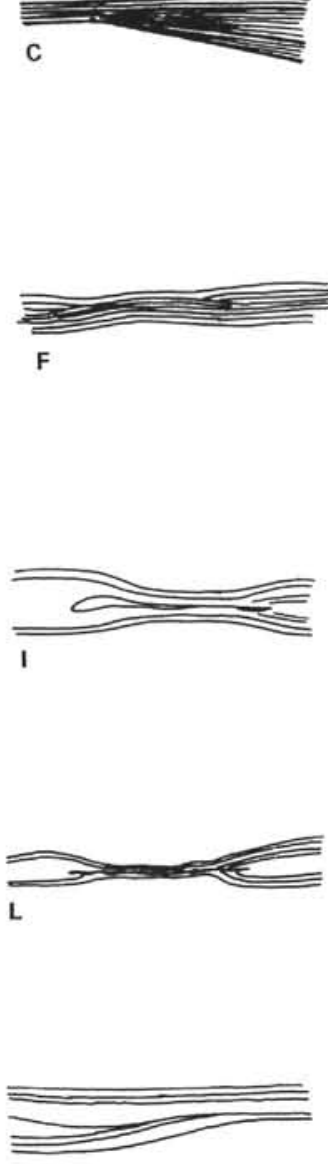

o

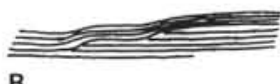

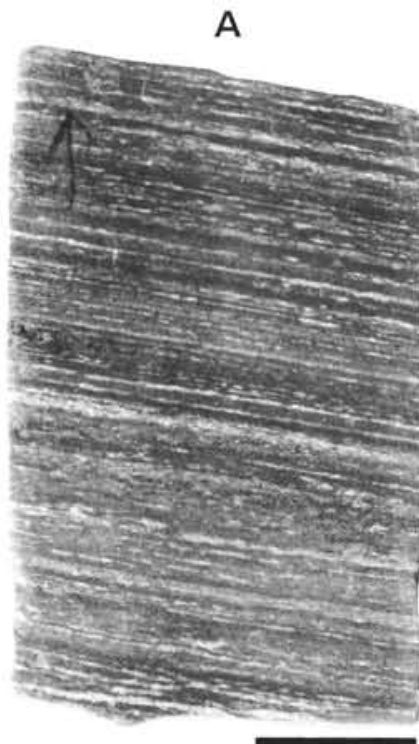

$1 \mathrm{~cm}$

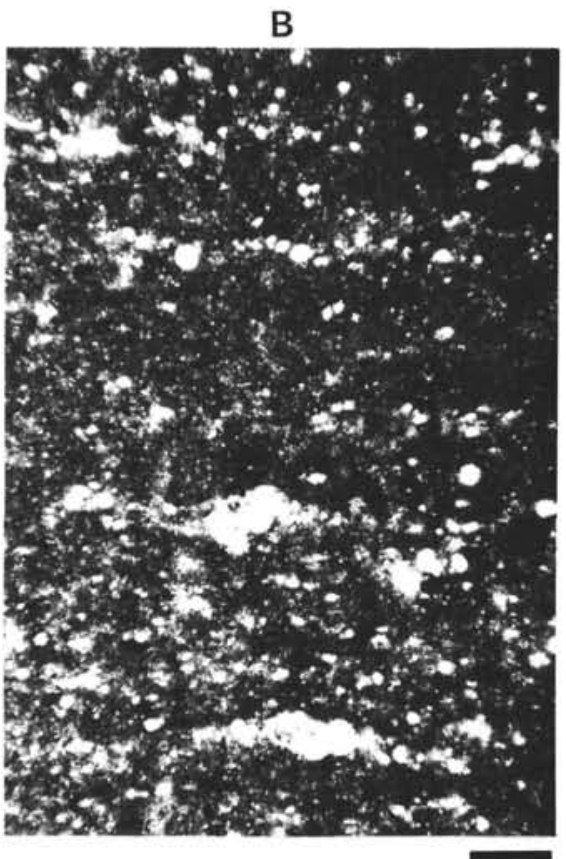

$0.25 \mathrm{~mm}$

Figure 43. Planktonic-bearing laminae in Albian deposits. A. Second-order and thirdorder laminae forming an alternation between dark units (micrite) and light ones with micrite and planktonic specimens (radiolarians essentially and foraminifers) in a limestone $\left(89 \% \mathrm{CaCO}_{3}\right)$; possible current-winnowing; deformations by compaction in the lower part of the sample (Albian, Sample 540-41-1, 134-138 cm). B. Second-order and third-order lamination in planktonic-rich (foraminifers essentially, few radiolarians) clayey limestone $\left(84 \% \mathrm{CaCO}_{3}\right)$; second-order alternation between more or less planktonic-rich layers; third-order lamination between sets of laminae, some rich in planktonic specimens and clay minerals, the others more calcareous and poor in planktonic specimens (Albian, Sample 540-42-1, 110-114 cm).

Figure 44. Deformation attributed mainly to the compaction in laminated deposits (Cores 535-52 to 535-67). A. Simple reduction of a laminae set. B-C. Same phenomenon with an obliteration (or extreme reduction and coalescence) of laminae. D-F. Reducing, followed by breaking (and retraction?) of laminae. G. Reduction, coalescence (and retraction?) of laminae. H-L. Exaggeration of the same

phenomenon leading to the formation of a breaking-plane; sliding possible along this plane. M-N. ment?) Top upward for all figures. Scale: $1 / 1$. 


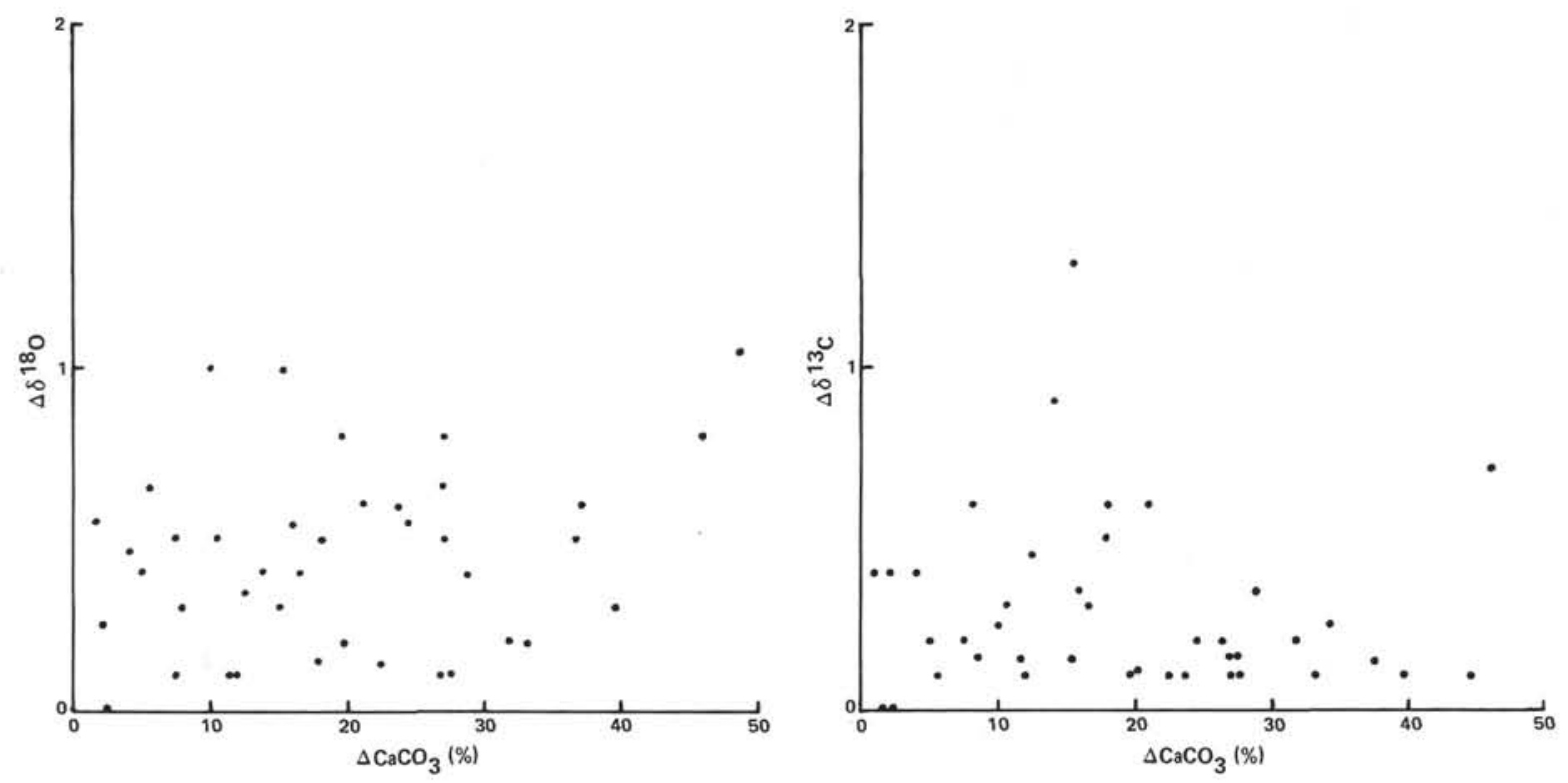

Figure 45. Differences between $\delta^{18} \mathrm{O}$ and $\delta^{13} \mathrm{C}$ values in each member of marl-limestone couplets versus differences between $\mathrm{CaCO}_{3}$ contents of deposit (Cretaceous at Sites 535 and 540). $\delta$ expressed as \%o versus PDB standard.

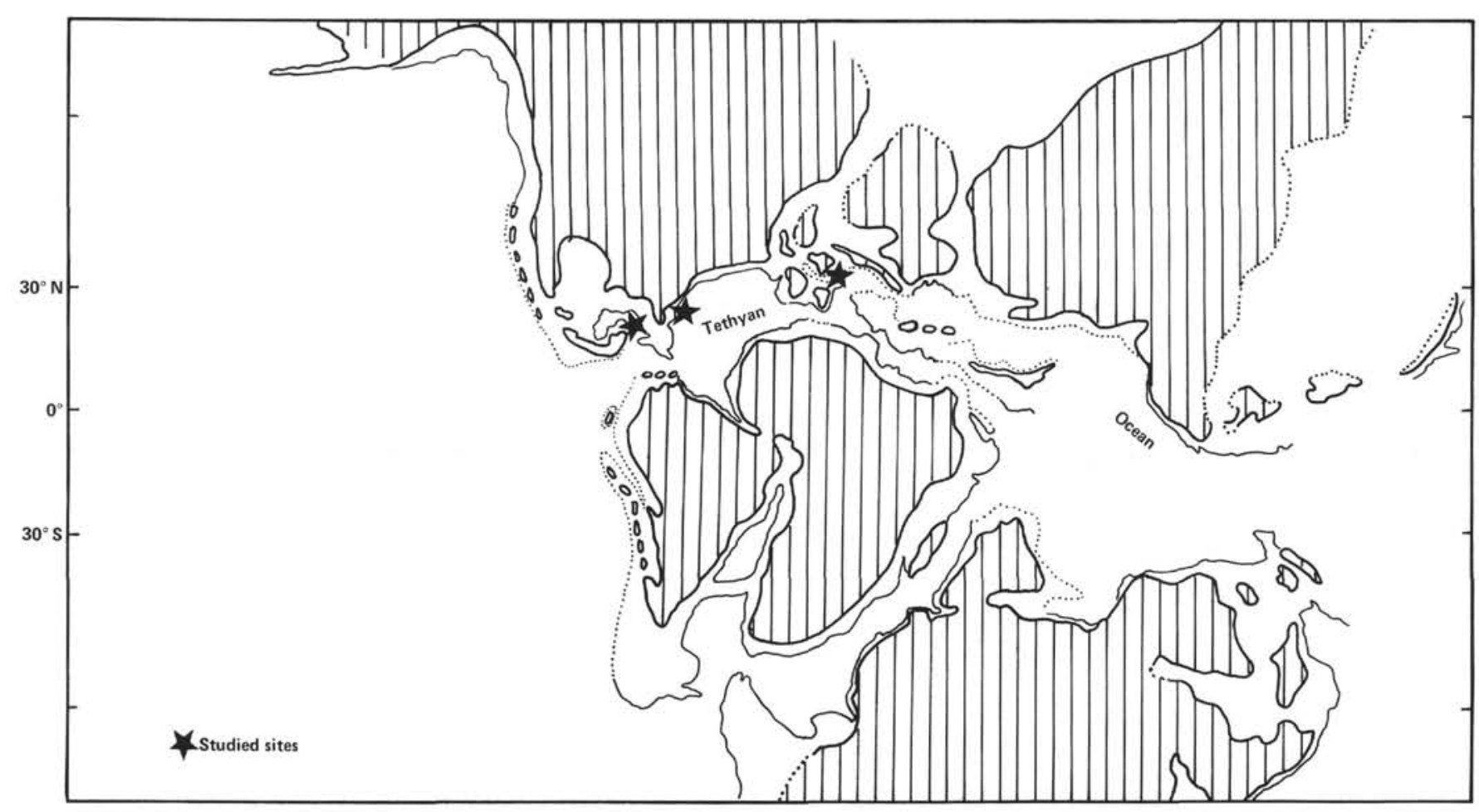

Figure 46. Tethyan Ocean during the Hauterivian (according to McSotay, 1980). 
APPENDIX A

$\mathrm{CaCO}_{3}$ Content of Selected Samples, Holes 535 and 540

\begin{tabular}{|c|c|c|c|}
\hline $\begin{array}{l}\text { Core-Section } \\
\text { (interval in } \mathrm{cm} \text { ) }\end{array}$ & $\begin{array}{c}\mathrm{CaCO}_{3} \\
(\%)\end{array}$ & $\begin{array}{l}\text { Core-Section } \\
\text { (interval in } \mathrm{cm} \text { ) }\end{array}$ & $\underset{(\%)}{\mathrm{CaCO}_{3}}$ \\
\hline Hole 535 & & Hole 535 (Cont.) & \\
\hline $22-3,35-44$ & 89.75 & $64-7,11-17$ & 93.00 \\
\hline $28-4,35-40$ & 74.76 & $65-2,128-132$ & 82.25 \\
\hline $31-5,54-56$ & 88.53 & $65-3,10-13$ & 74.00 \\
\hline $32-1,76-82$ & 79.68 & $19-22$ & 89.25 \\
\hline $93-98$ & 90.39 & $66-4,76-80$ & 59.00 \\
\hline $33-1,17-23$ & 87.25 & $109-115$ & 93.25 \\
\hline $33-4,4-16$ & 92.80 & $67-4,122-128$ & 71.50 \\
\hline $141-148$ & 82.08 & $139-146$ & 89.00 \\
\hline $33-5,0-6$ & 79.41 & $68-5,80-87$ & 93.00 \\
\hline $125-121$ & 71.50 & $97-101$ & 84.50 \\
\hline $35-4,82-86$ & 81.75 & $69-1,115-120$ & 65.23 \\
\hline $97-103$ & 92.75 & $71-1,72-76$ & 96.75 \\
\hline $35-6,132-139$ & 93.50 & $110-116$ & 89.25 \\
\hline $36-1,48-52$ & 91.05 & $71-3,122-124$ & 57.00 \\
\hline $52-56$ & 67.25 & $72-4,57-62$ & 88.25 \\
\hline $39-4,97-100$ & 91.25 & $64-66$ & 90.00 \\
\hline $103-108$ & 70.17 & $74-80$ & 80.50 \\
\hline $39-6,87-91$ & 84.35 & $87-89$ & 62.50 \\
\hline $41-6,44-47$ & 94.16 & $119-124$ & 94.75 \\
\hline 66-67 & 62.42 & $73-1,93-98$ & 43.00 \\
\hline $87-90$ & 89.50 & $101-108$ & 89.00 \\
\hline $42-3,54-54$ & 89.67 & $73-2,133-138$ & 90.25 \\
\hline $67-70$ & 84.82 & $74-1,101-111$ & 78.00 \\
\hline $74-78$ & 73.04 & $127-133$ & 91.68 \\
\hline $44-1,82-85$ & 75.95 & $74-2,33-36$ & 94.00 \\
\hline 88-94 & 91.91 & $75-3,64-69$ & 78.12 \\
\hline $46-2,26-28$ & 57.25 & $79-84$ & 94.5 \\
\hline $67-71$ & 94.50 & $77-2,115-119$ & 88.98 \\
\hline $47-1,6-9$ & 95.25 & $126-129$ & 64.93 \\
\hline $17-20$ & 47.00 & $79-1,16-19$ & 83.50 \\
\hline $49-3,76-79$ & 91.00 & $30-32$ & 93.00 \\
\hline $101-106$ & 85.50 & & \\
\hline $137-140$ & 95.50 & Hole 540 & \\
\hline $50-4,25-29$ & 91.25 & & \\
\hline $50-4,45-50$ & 56.64 & $37-1,40-43$ & 90.16 \\
\hline $51-1,32-37$ & 93.69 & $56-60$ & 91.00 \\
\hline $109-114$ & 94.00 & $75-78$ & 96.00 \\
\hline $51-4,94-99$ & 66.75 & $110-114$ & 95.59 \\
\hline $53-4,41-44$ & 78.25 & $39-1,1-5$ & 98.00 \\
\hline 61-64 & 86.00 & $13-17$ & 84.25 \\
\hline $54-2,50-56$ & 67.98 & $40-1,121-126$ & 93.50 \\
\hline $68-73$ & 87.50 & $131-133$ & 98.75 \\
\hline $54-4,60-68$ & 61.25 & $41-1,108-12$ & 94.50 \\
\hline $55-5,95-100$ & 59.75 & $130-133$ & 89.50 \\
\hline $115-120$ & 81.50 & $134-148$ & 88.50 \\
\hline $145-150$ & 92.50 & $42-1,90-94$ & 94.00 \\
\hline $55-6,115-121$ & 78.00 & $110-114$ & 83.75 \\
\hline $132-138$ & 89.50 & $42-3,8-10$ & 90.75 \\
\hline $57-4,30-35$ & 87.50 & $43-1,20-25$ & 90.00 \\
\hline $39-44$ & 60.50 & $109-112$ & 98.00 \\
\hline $53-54$ & 72.44 & $43-2,1-3$ & 96.00 \\
\hline $58-5,37-43$ & 91.25 & $13-18$ & 94.25 \\
\hline $59-65$ & 68.75 & $60-62$ & 98.50 \\
\hline $59-2,39-45$ & 89.50 & $45-1,118-122$ & 98.00 \\
\hline $74-79$ & 73.75 & $140-143$ & 94.00 \\
\hline $60-5,97-103$ & 73.25 & $45-2,64-71$ & 93.50 \\
\hline $60-6,25-32$ & 91.25 & $46-2,14-16$ & 87.50 \\
\hline $61-4,132-137$ & $\begin{array}{l}91.25 \\
67.75\end{array}$ & $47-1,51-53$ & 85.25 \\
\hline $142-148$ & 79.93 & $68-71$ & 84.50 \\
\hline $61-5,29-36$ & 84.61 & $48-1,101-104$ & 82.00 \\
\hline $62-2,20-26$ & $\begin{array}{l}84.01 \\
85.00\end{array}$ & $50-1,138-142$ & 93.00 \\
\hline $\begin{array}{r}02-2,20-20 \\
42-48\end{array}$ & $\begin{array}{l}85.00 \\
62.00\end{array}$ & $55-1,82-87$ & 92.00 \\
\hline $62-4,141-147$ & 95.00 & $97-100$ & 94.25 \\
\hline $63-2,46-53$ & 65.00 & $113-117$ & 95.00 \\
\hline $71-78$ & 67.00 & $63-1,26-28$ & 89.50 \\
\hline $63-4,37-44$ & 89.50 & $66-3,3-9$ & 93.75 \\
\hline $64-4,7-14$ & $\begin{array}{l}89.50 \\
72.00\end{array}$ & $30-34$ & 86.43 \\
\hline $143-150$ & 91.75 & $73-4,65-69$ & 92.12 \\
\hline $64-6,124-130$ & 92.25 & $75-2,23-27$ & 79.11 \\
\hline
\end{tabular}

APPENDIX B

Oxygen and Carbon Isotope Composition of Selected Samples, Holes 535 and 540

\begin{tabular}{llllll}
\hline $\begin{array}{c}\text { Core-Section } \\
\text { (interval in cm) }\end{array}$ & $\delta^{18} \mathrm{O}$ & ${ }^{13} \mathrm{C}$ & $\begin{array}{c}\text { Core-Section } \\
\text { (interval in cm) }\end{array}$ & ${ }^{18} \mathrm{O}$ & $\delta^{13} \mathrm{C}$ \\
\hline Hole 535 & & \multicolumn{7}{c}{ Hole 535 (Cont.) } \\
$32-1,76-82$ & -1.7 & 3.1 & $69-5,80-87$ & -3.7 & 1.7 \\
$32-1,93-98$ & -2.2 & 2.7 & $68-5,97-101$ & -3.8 & 1.8 \\
$33-1,17-23$ & -3.3 & 2.6 & $69-1,115-120$ & -2.9 & 1.6 \\
$33-4,11-16$ & -2.3 & 3.9 & $69-1,120-126$ & -3.5 & 1.7 \\
$33-5,115-121$ & -3.8 & 2.6 & $71-1,72-76$ & -4.0 & 0.8 \\
$35-4,97-103$ & -2.9 & 2.6 & $71-1,110-116$ & -4.5 & 1.0 \\
$35-6,132-139$ & -0.9 & 3.6 & $71-3,122-124$ & -3.7 & 0.9 \\
$36-1,48-52$ & -3.3 & 2.8 & $72-4,74-80$ & -4.5 & 1.0 \\
$36-1,52-56$ & -1.7 & 3.2 & $72-4,87-89$ & -3.9 & 1.0 \\
$39-4,97-100$ & -2.3 & 3.5 & $72-4,119-124$ & -4.5 & 0.8 \\
$39-4,103-108$ & -2.9 & 2.9 & $73-1,93-98$ & -3.4 & 1.2 \\
$41-6,44-47$ & -3.7 & 1.9 & $73-1,101-108$ & -4.2 & 0.5 \\
$41-6,66-67$ & -3.5 & 2.1 & $74-1,127-133$ & -3.9 & 0.9 \\
$41-6,87-90$ & -2.6 & 2.8 & $74-2,33-36$ & -3.9 & 0.9 \\
$42-3,67-70$ & -2.1 & 2.5 & $75-3,64-69$ & -3.8 & 0.9 \\
$42-3,74-78$ & -2.0 & 2.2 & $75-3,79-84$ & -4.3 & 1.2 \\
$46-2,26-28$ & -2.6 & 1.7 & $79-1,16-19$ & -4.6 & 1.0 \\
$46-2,67-71$ & -3.2 & 1.8 & $79-1,30-32$ & -4.1 & 1.3 \\
$49-3,101$ & & & &
\end{tabular}

Hole 540

\begin{tabular}{lll}
$37-1,56-60$ & -2.6 & 3.3 \\
$37-1,75-78$ & -1.2 & 3.1 \\
$37-1,110-114$ & -2.0 & 3.1 \\
$39-1,1-5$ & -2.3 & 3.6 \\
$39-1,13-17$ & -2.7 & 2.7 \\
$40-1,121-126$ & -1.7 & 2.5 \\
$40-1,131-133$ & -1.3 & 2.3 \\
$42-1,90-94$ & -2.0 & 1.8 \\
$42-1,110-114$ & -0.9 & 1.3 \\
$42-3,8-10$ & -1.7 & 1.9 \\
$43-1,20-25$ & -2.2 & 0.8 \\
$43-1,109-112$ & -2.5 & 1.4 \\
$45-1,118-122$ & -1.4 & 1.7 \\
$45-1,140-143$ & -1.8 & 1.3 \\
$46-2,35-37$ & -1.5 & 2.8 \\
$48-1,55-59$ & -2.0 & 2.8 \\
$48-1,101-104$ & -1.4 & 2.9 \\
$52-2,53-55$ & -1.1 & 2.6 \\
$52-2,72-75$ & -1.4 & 2.6 \\
$55-1,82-87$ & -1.9 & 2.5 \\
$55-1,97-100$ & -1.9 & 2.9 \\
$55-1,113-117$ & -2.4 & 2.9 \\
$56-1,79-85$ & -3.2 & 2.3 \\
$56-1,116-121$ & -0.9 & 3.4 \\
$58-2,76-81$ & -0.3 & 3.2 \\
$58-2,124-130$ & -1.7 & 2.6 \\
$63-1,4-7$ & -1.2 & 3.1 \\
$63-1,26-28$ & -1.1 & 2.3 \\
$66-3,3-9$ & -1.0 & 3.1 \\
$66-3,30-34$ & -1.8 & 3.1 \\
$67-3,107-113$ & -1.6 & 3.1 \\
$67-3,124-130$ & -1.6 & 2.2 \\
$78-3,86-90$ & -1.5 & 3.2 \\
$78-3,106-110$ & -1.5 & 3.0 \\
$79-1,67-71$ & -1.1 & 2.8 \\
$79-1,94-99$ & -1.8 & 3.2 \\
& & \\
& & \\
\hline & & \\
\hline
\end{tabular}

Note: $\delta^{18} \mathrm{O}$ and $\delta^{13} \mathrm{C}$ values in $\psi_{0}$ versus PDB standard. 
APPENDIX C

Carbonate, Organic Carbon, and Pyrolysis Data for Selected Samples, Hole 535

\begin{tabular}{|c|c|c|c|c|c|c|c|c|c|c|c|}
\hline \multirow{2}{*}{$\begin{array}{l}\text { Core-Section } \\
\text { (depth in } \\
\text { section in cm) }\end{array}$} & \multirow{2}{*}{$\begin{array}{l}\text { Sub-bottom } \\
\text { depth } \\
\text { (m) }\end{array}$} & \multirow{2}{*}{$\underset{(\%)}{C_{\min }}$} & \multirow{2}{*}{$\begin{array}{c}\mathrm{CaCO}_{3} \\
(\%)\end{array}$} & \multirow{2}{*}{$\begin{array}{c}\text { Organic } \\
\text { C (\%) }\end{array}$} & \multirow{2}{*}{$\begin{array}{c}\mathrm{T} \\
\left({ }^{\circ} \mathrm{C}\right)\end{array}$} & \multirow[b]{2}{*}{$\mathrm{HI} / \mathrm{CO}$} & \multirow[b]{2}{*}{$\mathrm{OI} / \mathrm{CO}$} & \multirow{2}{*}{$\begin{array}{c}\mathrm{mg} \mathrm{HC} / \mathrm{g} \\
\text { sample }\end{array}$} & \multirow{2}{*}{$\underset{(\%)}{C_{\text {pyrl }}}$} & \multirow{2}{*}{$\begin{array}{l}\text { IPROD }= \\
\frac{S_{1}}{S_{1}+S_{2}}\end{array}$} & \multirow[b]{2}{*}{ Lithofacies } \\
\hline & & & & & & & & & & & \\
\hline $35-4,82$ & 321.32 & 9.7 & 81 & 1.53 & 427 & 413 & 103 & 6.80 & 0.56 & 0.07 & \\
\hline $35-4,97$ & 321.47 & 11.8 & 99 & 0.17 & & $165(?)$ & 269 & 0.37 & 0.03 & 0.25 & \\
\hline $39-4,97$ & 359.47 & 11.1 & 93 & 0.42 & 426 & 186 & 143 & 0.88 & 0.07 & 0.11 & \\
\hline $39-4,103$ & 359.53 & 11.0 & 92 & 0.24 & 428 & 242 & 267 & 0.63 & 0.05 & 0.08 & \\
\hline $46-2,26$ & 420.76 & 7.4 & 62 & 2.34 & 427 & 380 & 81 & 9.26 & 0.77 & 0.04 & \\
\hline $46-2,67$ & 421.17 & 12.0 & 99 & 0.22 & 429 & 186 & 173 & 0.46 & 0.03 & 0.11 & \\
\hline $49-3,101$ & 450.01 & 7.7 & 65 & 2.49 & 416 & 403 & 78 & 10.45 & 0.87 & 0.04 & \\
\hline $49-3,111$ & 450.11 & 11.1 & 93 & 0.93 & 415 & 387 & 85 & 3.76 & 0.31 & 0.05 & \\
\hline $49-3,137$ & 450.37 & 11.6 & 97 & 0.24 & 424 & 129 & 129 & 0.61 & 0.05 & 0.10 & \\
\hline $51-1,32$ & 464.32 & 11.3 & 95 & 0.20 & 430 & 120 & 145 & 0.24 & 0.02 & 0.00 & \\
\hline $51-1,109$ & 465.09 & 11.5 & 96 & 0.39 & 426 & 197 & 120 & 0.77 & 0.06 & 0.00 & \\
\hline $51-4,94$ & 469.44 & 9.0 & 75 & 1.22 & 422 & 340 & 104 & 4.30 & 0.35 & 0.03 & \\
\hline $54-2,50$ & 489.00 & 8.0 & 67 & 1.65 & 417 & 393 & 88 & 6.79 & 0.56 & 0.04 & \\
\hline $54-2,68$ & 489.18 & 10.0 & 84 & 0.78 & 417 & 390 & 93 & 3.20 & 0.26 & 0.05 & \\
\hline $55-6,115$ & 505.15 & 8.9 & 75 & 2.16 & 410 & 414 & 77 & 9.39 & 0.78 & 0.05 & \\
\hline $55-6,132$ & 513.32 & 10.5 & 88 & 0.28 & 423 & 275 & 175 & 0.88 & 0.07 & 0.12 & Limestone \\
\hline $58-5,37$ & 531.37 & 11.0 & 82 & 0.43 & 423 & 367 & 86 & 1.86 & 0.15 & 0.15 & \\
\hline $58-5,59$ & 531.59 & 8.6 & 72 & 1.08 & 420 & 371 & 101 & 4.25 & 0.35 & 0.06 & \\
\hline $60-5,97$ & 549.97 & 8.8 & 74 & 1.37 & 419 & 388 & 85 & 5.66 & 0.47 & 0.06 & \\
\hline $60-6,25$ & 550.75 & 11.1 & 93 & 0.13 & & $100(?)$ & 315 & 0.21 & 0.01 & 0.40 & \\
\hline $62-2,42$ & 562.92 & 7.3 & 61 & 1.45 & 425 & 383 & 97 & 5.83 & 0.48 & 0.05 & \\
\hline $62-4,141$ & 566.91 & 11.3 & 95 & 0.15 & & 73 & 187 & 0.24 & 0.02 & 0.54 & \\
\hline $64-4,7$ & 583.57 & 8.5 & 71 & 1.68 & 418 & 455 & 80 & 8.14 & 0.67 & 0.06 & \\
\hline $64-4,143$ & 584.93 & 11.1 & 93 & 0.20 & 434 & 185 & 170 & 0.45 & 0.03 & 0.18 & \\
\hline $66-4,76$ & 602.26 & 7.2 & 61 & 2.45 & 417 & 512 & 70 & 13.28 & 1.10 & 0.06 & \\
\hline $66-4,109$ & 602.59 & 11.0 & 92 & 0.21 & 419 & 210 & 224 & 0.58 & 0.04 & 0.24 & \\
\hline $68-5,80$ & 617.30 & 11.2 & 93 & 0.20 & 420 & 75 & 160 & 0.20 & 0.01 & 0.25 & \\
\hline $68-5,97$ & 617.47 & 9.8 & 82 & 0.65 & 427 & 326 & 140 & 2.25 & 0.18 & 0.06 & \\
\hline $69-1,115$ & 620.65 & 7.1 & 60 & 1.63 & 426 & 425 & 113 & 7.42 & 0.61 & 0.07 & \\
\hline $69-1,120$ & 620.70 & 10.7 & 90 & 0.23 & 424 & 43 & 239 & 0.18 & 0.01 & 0.44 & \\
\hline $71-1,72$ & 638.20 & 11.4 & 96 & 0.08 & & & 325 & 0.29 & 0.02 & 0.18 & \\
\hline $71-1,110$ & 638.60 & 10.8 & 91 & 0.56 & 429 & 339 & 132 & 1.99 & 0.16 & 0.05 & \\
\hline $71-3,122$ & 641.72 & 6.3 & 53 & 1.90 & 425 & 439 & 85 & 8.72 & 0.72 & 0.04 & Marl \\
\hline $72-4,87$ & 651.87 & 8.8 & 74 & 2.35 & 419 & 304 & 78 & 7.49 & 0.62 & 0.05 & Limestone \\
\hline $72-4,119$ & 652.19 & 11.2 & 94 & 0.11 & & 18 & 336 & 0.16 & 0.01 & 0.87 & Limestone \\
\hline $73-1,93$ & 656.43 & 4.9 & 41 & 2.81 & 428 & 306 & 91 & 8.88 & 0.74 & 0.03 & Marl \\
\hline $73-1,101$ & 656.51 & 11.0 & 92 & 0.35 & 434 & 160 & 146 & 0.62 & 0.05 & 0.10 & \\
\hline $75-3,64$ & 677.14 & 9.1 & 76 & 0.27 & 427 & 137 & 304 & 0.44 & 0.03 & 0.16 & Limestone \\
\hline $75-3,79$ & 677.29 & 11.0 & 92 & 0.11 & & 27 & 291 & 0.06 & 0.00 & 0.50 & \\
\hline
\end{tabular}

Note: Analyses done by G. Deroo and J.-P. Herbin. $\mathrm{C}_{\operatorname{miner}}=$ mineral carbon; $\mathrm{HI}=$ hydrogen index; $\mathrm{CO}=$ organic carbon; $\mathrm{OI}=$ oxygen index; $\mathrm{C}_{\mathrm{pyrl}}=$ carbon extracted by pyrolysis; $\mathrm{IPROD}=$ production index $(\mathrm{mg} \mathrm{HC} / \mathrm{g}$ sample). 